Dissertation presented to the Animal Science Graduate Program of the Universidade Federal de Viçosa, in partial fulfillment of the requirements for degree of Magister Scientiae.

VIÇOSA

MINAS GERAIS - BRASIL

2011 


\title{
LINKAGE DISEQUILIBRIUM AND HAPLOTYPE BLOCK STRUCTURE IN SIX COMMERCIAL PIG LINES
}

\author{
Dissertation presented to the \\ Animal Science Graduate \\ Program of the Universidade \\ Federal de Viçosa, in partial \\ fulfillment of the requirements for \\ degree of Magister Scientiae.
}

Aprovada: 21 de fevereiro de 2011

Profa.Simone E. F. Guimarães

(Co-orientador)
Prof. Fabyano Fonseca e Silva

(Co-orientador)

Prof. Luiz Alexandre Peternelli

Prof. Leonardo Lopes Bhering 
"I must endure the presence of two or three caterpillars if I wish to become acquainted with the 6utterflies"

The Little Prince - Antoine de Saint-Exupery 


\section{ACKNOWLEDGEMENTS}

To the Universidade Federal de Viçosa (UFV) and the Animal Science Department, for the opportunity to take a course.

To the Conselho Nacional de Desenvolvimento Científico e Tecnológico (CNPq), for the scolarship.

To the Institute for Pig Genetics (IPG), for the data.

To Embrapa Gado de Leite (Juiz de Fora, Minas Gerais), for the contribution to this study.

To my adviser Paulo Sávio Lopes, for his teaching and confidence in me since graduation.

To my co-adviser, Simone E.F. Guimarães, for the lessons that extend beyond academia and for her encouragement.

To my co-advisor Fabyano F. Silva for the teaching, enthusiasm and software routines $R$.

To Marcelle from Embrapa Gado de Leite, for the pipelines that were important for this study development and all the time she spent with me.

To the workers at the Granja de Melhoramento de Suínos, for the teachings and friendship.

To my friends from LABTEC, for companionship, conviviality, coffee breaks and moments of relaxation.

To my friends from the Animal Breeding and Veterinary Department, for the fellowship, friendship and laughter.

To my friends from the graduation course and Viçosa, for the contributing to my growth as a person.

To my dear friend Thaís, for all these years of friendship and complicity.

To my friend Dayana, for fellowship, care and the moments of fun that were necessary for this work.

To my mother Irene, for being an example of a courageous and strong woman, who has always been my greatest motivator and source of admiration and inspiration.

To my father Rosivaldo, for being an example of a diligent man and contributing to the formation of my character.

To my sister Rosana and my brother Junior, for being my full time friends and for us being always united even when apart.

To all of MEIMEI, for making the Saturday a special day.

To God, for giving me strength in the hardest times, for being my comfort, my friend and protector at all times. 


\section{BIOGRAPHY}

Renata Veroneze, daughter of Rosivaldo Veroneze and Irene Nunes Veroneze, born on July 27, 1984, in Capivari, São Paulo, Brazil.

She began her studies in Animal Science at the Universidade Federal de Vicosa in 2004 and graduated in Animal Science in January 2009. In March 2009, she began s the master's degree in Animal Science at the same University. 


\section{SUMMARY}

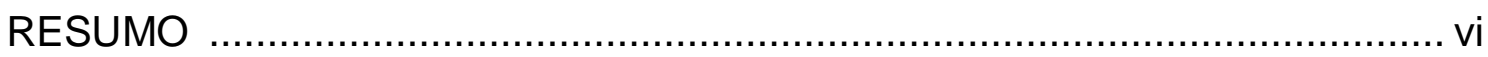

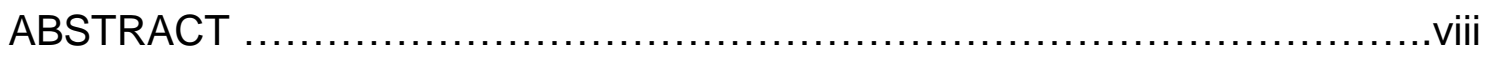

CHAPTER 1

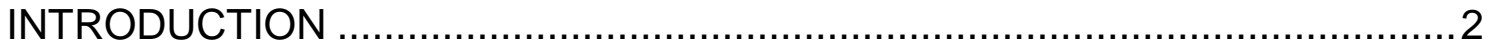

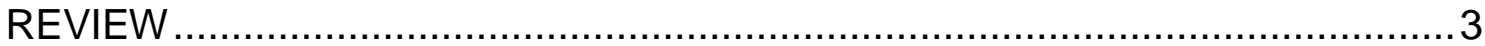

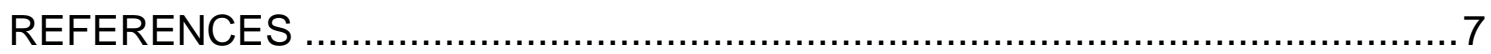

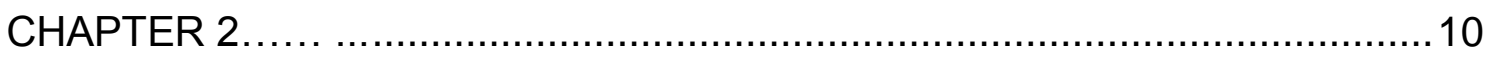

LINKAGE DISEQUILIBRIUM AND HAPLOTYPE BLOCK STRUCTURE IN SIX COMMERCIAL PIG LINES ................................................................

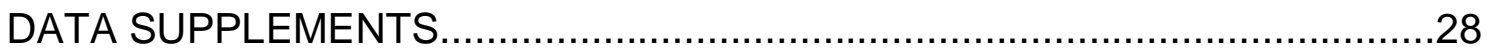




\section{RESUMO}

VERONEZE, Renata, M.Sc., Universidade Federal de Viçosa, fevereiro de 2011. Desequilíbrio de ligação e blocos de haplótipo em seis linhas comerciais de suíno. Orientador: Paulo Sávio Lopes. Co-orientadores: Simone Eliza Facioni Guimarães e Fabyano Fonseca e Silva.

O sucesso de estudos de associação e, consequentemente, a seleção genômica dependem da densidade de marcadores utilizados nas análises, a qual, por sua vez, é determinada pela extensão do desequilíbrio de ligação (LD) ao longo do genoma. O LD é organizado em blocos de haplótipos, separados por hot spots de recombinação. Essa organização do LD permite a seleção de um conjunto de SNPs que caracterizam o bloco, o que constitui uma forma adequada de escolher SNPs. O objetivo deste estudo foi estimar a extensão do desequilíbrio de ligação e o tamanho dos blocos de haplótipos de seis linhas comerciais de suínos. Foram genotipados 2050 animais com o SNP chip de $60 \mathrm{~K}$ para suínos da Illumina. Os marcadores foram filtrados com base na $\operatorname{MAF}(>0,05)$ e Equilíbrio de Hardy-Weinberg ( $p$ valor $>0,001)$, o que resultou na utilização de, em média, 34021 SNPs para análises subsequentes. O programa Haploview foi usado no cáculo do LD de todos os pares de SNPS sintênicos, como também na construção dos blocos de haplótipo. O tamanho dos blocos de haplótipo das diferentes linhas foi comparado, utilizando-se 0 procedimento PROC MIXED do software SAS. Marcadores entre $105-175 \mathrm{~Kb}$ de distância apresentaram $r^{2}$ (correlação entre frequências gênicas) médio acima de 0,3 para todas as linhas, o qual é considerado um bom limiar para estudos de associação. Assim, mapas com um SNP, a cada $105 \mathrm{~Kb}$, seriam adequados a esse tipo de análise. Teoricamente, O LD decresce com o aumento da distância entre os SNPs, entretanto, alguns cromossomos $(1,4,5$, $7,9,11,12,13,14,15$ e 16) apresentaram $r^{2}$ elevado entre SNPs distantes em todas as linhas estudadas, o que poderia ser resultado de erros na distância e na posição dos marcadores no mapa utilizado. Em alguns cromossomos (2 e 18) alto $r^{2}$, entre SNPs distantes, foi observado apenas em algumas linhas, 0 que poderia ter sido causado por uma série de fatores que influenciam o LD. Entretanto, por tratar-se de linhas diferentes, provavelmente elas possuem histórico, endogamia e cruzamentos distintos. Dessa maneira, pode-se 
pressupor que esse efeito teria sido causado pela seleção, uma vez que existem características de importância econômica que com certeza, em algum momento, foram selecionadas em mais de uma linha. O tamanho médio dos blocos de haplótipos foi de $287,81 \mathrm{~Kb}$, com predominância de blocos pequenos com menos de $50 \mathrm{~Kb}$. Nenhuma linha apresentou blocos maiores ou menores que as demais, em todos os cromossomos, não existindo, portanto, um padrão que possa discriminar as diferentes linhas. De acordo com a extensão do LD observado neste estudo, seriam necessários 22915 SNPs informativos (MAF > $0,05)$ para estudos de associação que abrangerem todo o genoma. O elevado desequilíbrio de ligação, observado entre pares de SNPs distantes, pode ter sido causado por erros no mapa e, em alguns casos, por seleção, entretanto para confirmação dessa última hipótese, seria necessário um estudo mais aprofundado das regiões onde esses SNPs se encontram. 


\section{ABSTRACT}

VERONEZE, Renata, M.Sc., Universidade Federal de Viçosa, February 2011. Linkage disequilibrium and haplotype block structure in six commercial pig lines. Adviser: Paulo Sávio Lopes. Co-Advisers: Simone Eliza Facioni Guimarães and Fabyano Fonseca e Silva.

The success of association studies and genomic selection depends on marker density, which is determined by the linkage disequilibrium extended across the genome. The LD is organized into haplotypes blocks separated by recombination hot spots and this organization allows the selection of a set of SNPs that label the blocks. The objective of the present study was to estimate the linkage disequilibrium extent and haplotype block size of six commercial pig lines. Two thousand and fifty animals were genotyped using Illumina Porcine SNP60K. The MAF and Hardy-Weinberg equilibrium were used to filter the SNPs, which resulted, on average, in the use of 34021 markers for the subsequent analysis. The data were submitted to Haploview to calculate the LD for all SNP pairs and the haplotype blocks construction. The haplotype block size for all six lines was compared using the PROC MIXED procedure of SAS in a model with the number of SNPs per block as covariate. In markers distant 105 - $175 \mathrm{~Kb}$ the average $\mathrm{r}^{2}$ was above 0.3 for all lines, which is considered a usable threshold for association studies; therefore maps with one SNP every $105 \mathrm{~Kb}$ would be suitable for this type of analysis. Following the theory, the LD decreases when the distance between SNPs increases, but high $r^{2}$ was observed between distant SNPs for some chromosomes (1, 4, 5, 7, 9, 11, 12, $13,14,15$ and 16) in all lines that could be produced by errors in the marker distance and position of the map used. In some chromosomes (2 and 18) high $r^{2}$ between distant SNPs was observed only for some lines, which could be a result of a number of factors that influence the LD. However, the studied lines probably have different history and inbreeding. It could be argued that this is a selection effect, as these lines at a certain moment were certainly selected for traits of economic importance. Although the overall average haplotype block size was $287.81 \mathrm{~Kb}$, a predominance of blocks with less than $50 \mathrm{~Kb}$ was observed for all lines. There is not a line that presents smaller or bigger blocks than the others in every chromosome; therefore there was no pattern that could 
be used to discriminate the lines.. According to the LD extent observed in this study, 22915 informative SNPs (MAF > 0.05) would be necessary for whole genome association studies for the six lines analysed. The high linkage disequilibrium observed between distant SNPs may have been caused by map errors and in other cases by selection. Nevertheless, to confirm the last hypothesis a detailed study would be necessary of the regions where these SNPs are found. 
CHAPTER 1 


\section{INTRODUCTION}

Selection based on phenotype information has provided most of the pig genetic progress. Despite the success of this approach, the interest in the use of molecular information for selection is growing. In addition, considerable increase in the available molecular information has been experimented. The pig genome has been sequenced (www.ensembl.org/sus scrofa) and the number of identified SNPs (Single Nucleotide Polymorphism) markers is growing fast which in turn enables an increase in porcine molecular genetic studies.

A successful association analysis and consequently the genomic selection depend on the marker density which is determined by the linkage disequilibrium (LD) extent across the genome (Khatkar, et al., 2008). LD is defined as the nonrandom association between alleles at different loci and is influenced by population history, breeding system and the pattern of geographic subdivision (Slatkin, 2008).

These allelic associations are mainly due to physical proximity; but distant SNPs pairs might be in complete LD. In addition, the LD extent can vary tremendously from one region to another. Despite this apparent complexity, the LD is organized into discrete blocks of haplotypes that show high LD, separated by putative hot spots of recombination (Daly, et al., 2001; Ardlie, et al., 2002; Jeffreys, et al., 2001). It is an important characteristic, because it makes it possible to select a set of SNPs in a rational way, so that SNPs that label a haplotype-block can be selected for association mapping (Johnson, et al., 2001).

Studies of linkage disequilibrium have shown that the LD extension in livestock is higher than in human populations, that can be explained by the small effective population size, selection and genetic drift, which are common features in livestock (McRae, et al. 2002).

According to Khatkar et al. (2008) significant LD extends to $40 \mathrm{~Kb}$ in Australian Holstein-Friesian cattle and the mean squared correlation of the alleles at two loci $\left(\mathrm{r}^{2}\right)$ is 0.024 among syntenic SNPs (Single Nucleotide Polimorfism) is 0.024. Qanbari et al. (2010) found 712 haplotype blocks in German Holstein cattle and the estimated average block size was $164 \pm 177 \mathrm{~Kb}$.

In pigs Du et al. (2007) used 4,500 SNPs markers and 6,000 pigs animals and identified lower LD than that previously reported using microsatellite markers, in this study for SNPs pairs 3 centiMorgan (cM) apart the average $r^{2}$ was equal to 0.1. Amaral et al. 
(2008) genotyped three genomic regions using 371 SNP markers in several pig breeds, and reported that the $\mathrm{LD}$ extended up to $2 \mathrm{cM}$ in European breeds and up to $0.05 \mathrm{cM}$ in Chinese breeds. They also observed that the European breeds have larger haplotype blocks $(>400 \mathrm{~kb})$ than the Chinese $(10 \mathrm{~kb})$. Using SNP markers, Uimari and Tapio (2011) reported an average $r^{2}$ of 0.47 and 0.49 for Finnish Landrace and Finnish Yorkshire, respectively, for SNPs $30 \mathrm{~Kb}$ apart.

LD studies elucidate the recombination history of a population, which is valuable information for selecting SNPs for association and genome selection studies.

\section{REVIEW}

\subsection{Pig breeding}

Pork is the most consumed meat around the world and it was estimated that 101 million tons of pork were produced in 2010 (http://www.abipecs.com.br/). In Brazil, the pork industry is very important and the country produces approximately 3 million tons of pork meat and its chain generates 630 thousand direct jobs (http://www.abipecs.com.br/). In addition, because of the physiological similarity with humans, the pig is an important animal model to study diseases (Lunney, 2007).

To date, most of the pig genetic progress was obtained by selection using phenotypic information, without knowledge of the number of genes that affect the trait or the effects of each gene (Rothschild, 2008). Despite the success of phenotype based selection, there is a growing interest in the use of molecular information for selection, especially for traits with low heritability, that are difficult to measure or that can only be measured in one sex or late in life and also in traits that require the animal to be slaughtered (Dekkers and Rothschild, 2007).

Considerable increase in the available molecular information has been experimented, the pig genome has been sequenced (www.ensembl.org/sus_scrofa) and the number of identified SNPs markers is growing fast. SNP genotyping will allow for "whole genome association trials" and discovery of many significant associations (Rothschild, 2008), which are the basic information to perform genomic selection.

\subsection{Single-nucleotide polymorphisms (SNPs) markers}

A SNP marker is only a single base change in a DNA sequence, nevertheless for such change to be considered as a SNP the least frequent allele should have a frequency of 
$1 \%$ or greater (Vignal, et al., 2002). Most of the SNP markers are bi-allelic, because of the low probability of two independent base changes occurring in a single position. Single-nucleotide polymorphisms are the most frequent type of variation found in DNA and they are valuable markers for high-throughput genetic mapping, genetic variation studies and association mapping. It was estimated that the human genome contains more than 10 million SNPs (Gunderson, et al., 2005), with one SNP every 1,000 bases or less (Weiner and Hudson, 2002). SNPs can be found in coding or regulatory regions, but in most cases they are found in intergenic spaces with no defined function (Caetano, 2009).

\section{Linkage disequilibrium (LD)}

Linkage disequilibrium (LD) is a nonrandom association between alleles at different loci. These allelic associations are mainly due to physical proximity but are also influenced by population history and evolutionary forces (Khatkar, 2008).

The LD extent within a population plays an important role in gene mapping and genome association studies (Bohmanova, 2010); it determines the number of markers that will be required for successful association mapping and genomic selection. The influence of the population history on LD extent results in differences in this measurement between populations and consequently in the effectiveness of genome association studies.

LD extent depends on the local recombination rates; therefore the LD extent is higher in regions with a low recombination rate, which include the $\mathrm{Y}$ chromosome, parts of the $\mathrm{X}$ chromosome and regions near the centromere in autosomes. On the other hand, regions with a high recombination rate, such as euchromatin and small regions known as hotspots (Jeffreys, et al., 2001) have small LD extent between two loci.

The population history, breeding system and pattern of geographic subdivision reflect the LD throughout the genome, while the history of natural selection, gene conversion, mutation and other forces that cause gene-frequency evolution reflect the LD in each genomic region (Slatkin, 2008).

Little information was found in the consulted literature about pig linkage disequilibrium estimated using SNP markers. Using SNPs Du et al. (2007) identified lower LD than that previously reported using microsatellite markers. In this study 6,000 pigs were genotyped with approximately 4,500 SNPs and for markers pairs 3 centiMorgan (cM) apart the average $r^{2}$ was equal to 0.1. Amaral et al. (2008) genotyped three genomic regions using 371 SNP markers in several pig breeds and reported that Chinese breeds 
have lower LD extending $(0.05 \mathrm{cM})$ than European breeds $(2 \mathrm{cM})$ and they also observed that the European breeds have larger haplotype blocks $(>400 \mathrm{~kb})$ than the Chinese $(10 \mathrm{~kb})$.

\section{Measurement of Linkage disequilibrium}

The first linkage disequilibrium measurement (D) was proposed by Lewontin (1964) which quantifies the linkage disequilibrium as the difference between the observed frequency of a two-locus haplotype and the expected frequency if the alleles were segregating at random. So, it can be calculated as demonstrated below:

$$
D_{i j}=P_{i j}-p_{i} q_{j}
$$

where, $P_{i j}$ is the observed frequency of the haplotype that consists of alleles $\mathrm{i}$ and $\mathrm{j} ; p_{i}$ is the frequency of the allele $\mathrm{i}$ and $q_{j}$ is the frequency of the allele $\mathrm{j}$.

The $\mathrm{D}$ is of little use for LD measure, because of its dependence on allele frequencies (Ardlie, et al., 2002). Consequently, several alternative measures were developed, the two most common are $D^{\prime}$ (Lewontin, 1964) and $\mathrm{r}^{2}$ (Hill and Robertson, 1968).

For any two biallelic loci, $D^{\prime}$ is defined as:

$$
D^{\prime}=\sum_{i=1}^{2} \sum_{j=2}^{2} p_{i} q_{j} \frac{\left|D_{i j}\right|}{D_{\max }}
$$

where,

$$
D_{\text {max }}=\left\{\begin{array}{l}
\min \left[p_{i} q_{j},\left(1-p_{i}\right)\left(1-q_{j}\right)\right] \text { if } D_{i j}<0 \\
\min \left[p_{i}\left(1-q_{j}\right),\left(1-p_{i}\right) q_{j}\right] \text { if } D_{i j}>0
\end{array}\right.
$$

$D^{\prime}$ ranges from 0 to $1, D^{\prime}$ equals 1 (complete LD) and means that there is no recombination between the two SNPs, in other words, one allele at each locus is completely associated with an allele at the other locus. Values $D^{\prime}<1$ does not have a clear interpretation (Du, et al., 2007).

The other LD measure $\left(\mathrm{r}^{2}\right)$ is the correlation of gene frequencies for alleles at two sites. It is defined as:

$$
r^{2}=\frac{D_{i j}^{2}}{p_{1} p_{2} q_{1} q_{2}}
$$

where, $p_{1} p_{2} q_{1} q_{2}$ is the product of the four allele frequencies at the two loci. 
For a pair of biallelic loci, $\mathrm{r}^{2}=1$ if there are two haplotypes for two biallelic loci and the allele frequency at both loci are identical. Du et al. (2007) compared the effect of the minor allele frequencies (MAF) on the $D^{\prime}$ and $r^{2}$ measurements and demonstrated that $D^{\prime}$ suffers greater influence of the MAF and concluded that the $\mathrm{r}^{2}$ is considerably more robust than $D^{\prime}$. Bohmanova et al. (2010) verified that $D^{\prime}$ is strongly dependent on the allele frequency, in addition, they demonstrated that $D^{\prime}$ is inflated in small-sized samples.

\section{Haplotype block structure}

LD has a tendency to decrease over large distances; nevertheless distant SNPs pairs might be in complete LD. In addition, tremendous differences can occur in the extent of LD from one genomic region to another (Wall, et al. 2003).

Despite this apparent complexity of the observed LD patterns, some studies have demonstrated that the LD is organized into discrete blocks of haplotypes that show high LD, separated by possible hot spots of recombination (Daly, et al., 2001; Ardlie, et al., 2002; Jeffreys, et al., 2001). The fact that the LD is often discontinuous produces haplotypic profiles across the genome because of the variation in local recombination rates, mutation rates and genetic hitchhiking (Jeffreys, et al., 2001).

A haplotype block was defined by Reich et al. (2001) as a contiguous set of markers in which the average $D^{\prime}$ (the standardized coefficient of LD) is greater than some predetermined threshold. Another definition is given by Patil et al. (2001); based on the concept of "chromosome coverage," with a haplotype block containing a minimum number of SNPs that account for a majority of common haplotypes.

In biological terms the haplotype block can be defined by examining the patterns of recombination across each region, since the haplotype blocks represent regions inherited without substantial recombination in the ancestors of the current population (Gabriel, et al., 2002).

Diverse approaches to define a LD block have been proposed but the simplest way is to establish a LD threshold to include the SNPs in a block without considering the information of the haplotype-phase (Tishkoff and Verrelli, 2003).

The approach proposed by Gabriel et al. (2002) is based on $D^{\prime}$ as a measure of allelic association. The authors considered that a pair of alleles is in "strong LD" when the one-sided upper $95 \%$ confidence bound on $D^{\prime}$ is 0.98 and the lower bound is above 0.7 . 
In addition, for these authors the haplotype block is a region over which a very small proportion (5\%) of comparisons among informative SNP pairs show strong evidence of historical recombination, and the term "strong evidence for historical recombination" pairs where the upper confidence bound on $D^{\prime}$ is less than 0.9 .

The haplotype-block has important implications for association mapping because it makes it possible to select a set of SNPs that label the haplotype-block, which is a rational way to choose SNPs for association studies (Johnson, et al., 2001). In addition, haplotype block distribution and structure may provide a wider comprehension of the distribution of genetic variation throughout the genome (Wang, et al., 2002).

\section{REFERENCES}

Amaral A. J., H. J. Megens, R. P. M. A. Crooijmans, H. C. M. Heuven, M. A. M. Groenen. 2008. Linkage disequilibrium decay and haplotype block structure in the pig. Genetics. 179:569-579.

Ardlie K. G., L. Kruglyak, M. Seielstad. 2002. Patterns of linkage disequilibrium in the human genome. Nat. Rev. Genet. 3:299-309.

Associação Brasileira da Indústria Produtora e Exportadora de Carne Suína http://www.abipecs.org.br/.

Bohmanova J., M. Sargolzaei, F.S. Schenkel. 2010. Characteristics of linkage disequilibrium in North American Holsteins. BMC genomics. 11:421.

Caetano A.R. 2009. Marcadores SNP : conceitos básicos, aplicações no manejo e no melhoramento animal e perspectivas para o futuro. R. Bras. Zootec. 38:64-71.

Daly M. J., J. D. Rioux, S. F. Schaffner, T. J. Hudson, E. S. Lander 2001. Highresolution haplotype structure in the human genome. Nature genetics, 29:229-233.

Dekkers J., M. Rothschild. 2007. New tools to make genetic progress. Proc. London Swine Conference - Today's Challenges... Tomorrow's Opportunities, 1:53-63

Du, F. X., A. C. Clutter and M. M. Lohuis. 2007. Characterizing linkage disequilibrium in pig populations. Int. J. Biol. Sci. 3:166-178.

Ensembl - www.ensembl.org/sus_scrofa.

Gabriel S. B., S. F. Schaffner, H. Nguyen, J. M. Moore, J. Roy, B. Blumenstiel, J. Higgins, M. DeFelice, A. Lochner, M. Faggart, S. N. Liu-Cordero, C. Rotimi, A. Adeyemo, R. Cooper, R. Ward, E. S. Lander, M. J. Daly, D. Altshuler. 2002. The structure of haplotype blocks in the human genome. Science. 296:2225-9. 
Gunderson K. L., F. J. Steemers, G. Lee, L. G. Mendoza, M. S. Chee. 2005. A genomewide scalable SNP genotyping assay using microarray technology. Nature genetics. $37: 549-54$.

Hill W. G and A. Robertson. 1968. Linkage disequilibrium in finite populations. Theoret. Appl. Genetics. 38:226-231.

Jeffreys A. J, L. Kauppi, R. Neumann. 2001. Intensely punctate meiotic recombination in the class II region of the major histocompatibility complex. Nature genetics. 29:217-222.

Johnson G. C. L., L. Esposito, B. J. Barratt, A.N. Smith, J. Heward, G. Di Genova, H. Ueda, H. J. Cordell, I. A. Eaves, F. Dudbridge, R. C. J. Twells, F. Payne, W. Hughes, S. Nutland, H. Stevens, P. Carr, E. Tuomilehto-Wolf, J. Tuomilehto, S. C. L. Gough, D. G. Clayton and J. A. Todd. 2001. Haplotype tagging for the identification of common disease genes. Nature genetics. 29:233-238.

Khatkar M. S., F. W. Nicholas, A. R. Collins, K. R. Zenger, J. Al Cavanagh, W. Barris, R. D. Schnabel, J. F. Taylor and H. W. Raadsma. 2008. Extent of genome-wide linkage disequilibrium in Australian Holstein-Friesian cattle based on a high-density SNP panel. BMC Genomics. 9:187.

Lewontin R. C. 1964. The Interaction of Selection and Linkage. I. General Considerations; Heterotic Models. Genetics, 49:49-67.

Lunney JK. Advances in swine biomedical model genomics. 2007. Int. J. Biol. Sci. $3: 179-84$.

McRae A. F., J. C. McEwan, K. G. Dodds, T. Wilson, A. M. Crawford and J. Slate. 2002. Linkage disequilibrium in domestic sheep. Genetics. 160:1113-1122.

Patil N., A. J. Berno, D. A. Hinds, W.A. Barrett, J. M. Doshi, C. R. Hacker, C. R. Kautzer, D. H. Lee, C. Marjoribanks, D. P. McDonough, B. T. N. Nguyen, M. C. Norris, J. B. Sheehan, N. Shen, D. Stern, R. P. Stokowski, D. J. Thomas, M. O. Trulson, K. R. Vyas, K. A. Frazer, S. P. A. Fodor, D. R. Cox. 2001. Blocks of limited haplotype diversity revealed by high-resolution scanning of human chromosome 21. Science. 294:1719-23.

Qanbari S, E. C. G. Pimentel, J. Tetens, G. Thaller, P. Lichtner, A.R. Sharifi, H. Simianer. 2010. The pattern of linkage disequilibrium in German Holstein cattle. Animal Genetics. 41:346-356. 
Reich D. E. , M. Cargill, S. Bolk, J. Ireland, P.C. Sabeti, D.J. Richter, T. Lavery, R. Kouyoumjian, S. F. Farhadian, R. Ward, E. S. Lander. 2001. Linkage disequilibrium in the human genome. Nature. 411:199-204.

Rothschild M. F. 2008. Swine Genetic Challenges of the Future: One man's thoughts. Proc. National Swine Improvement Federation Annual Conference and Symposium.

Slatkin, M. 2008. Linkage disequilibrium - understanding the evolutionary past and mapping the medical future. Nat. Rev. Genet. 9:477-485.

Tishkoff S. A., B. C. Verrelli. 2003. Role of evolutionary history on haplotype block structure in the human genome: implications for disease mapping. Current Opinion in Genetics \& Development. 13:569-575.

Uimari, P. and M. Tapio. 2011. Extent of linkage disequilibrium and effective population size in Finnish Landrace and Finnish Yorkshire pig breeds. J. Anim. Sci. 89:609-614.

Vignal A., D. Milan, M. SanCristobal, A. Eggen. 2002. A review on SNP and other types of molecular markers and their use in animal genetics. Genet. Sel. Evol. 34:275-305.

Wall J. D., J. K. Pritchard. 2003. Haplotype blocks and linkage disequilibrium in the human genome. Nat. Rev. Genet. 4:587-97.

Wang N., J. M. Akey, K. Zhang, R. Chakraborty, L. Jin. 2002. Distribution of recombination crossovers and the origin of haplotype blocks: the interplay of population history, recombination, and mutation. Am. J. Hum. Genet. 71:1227-34.

Weiner M. P., T. J. Hudson. 2002. Introduction to SNPs: discovery of markers for disease. BioTechniques. 10 (Suppl:4-7):12-3. 
CHAPTER 2 


\section{Linkage disequilibrium and haplotype block structure in six commercial pig lines ${ }^{1}$}

ABSTRACT: Linkage disequilibrium (LD) across the genome is critical information for association studies and consequently for genome selection, since it determines the number of SNPs that should be used for a successful association analysis. Some studies demonstrated that the LD is organized into discrete blocks of haplotypes that show high LD, separated by possible hot spots of recombination. These haplotype-blocks have important implications for association mapping because they make it possible to select a set of SNPs that label the haplotype-block, which is a coherent way of selecting useful SNPs. Only a few LD studies with pigs using SNPs markers are available and some of them are restricted to specific genomic regions. We estimated the LD at different marker distances and calculated the average haplotype block size for six pig lines; we also compared the lines block size. Six commercial pig lines (1, 2, 5, 6, 4 and 3) were genotyped using the Illumina PorcineSNP60K Beadchip; on average a panel of 34,021 SNPs with an average 0.285 MAF was included in the analysis. The linkage disequilibrium declined as a function of the distance, but high LD was observed between distant SNP pairs especially in chromosomes 1, 4, 5, 7, 9, 11, 12, 13, 14, 15 and 16. All lines had an average $\mathrm{r}^{2}$ above 0.3 in markers $105-175 \mathrm{~Kb}$ apart. The estimated average block size was $287.81 \mathrm{~Kb}$. However, a predominance of blocks with less than $50 \mathrm{~Kb}$ in all lines was observed. Except in two cases, no pig line showed higher or smaller block size than any of the other lines for all chromosomes. At least one SNP every $105 \mathrm{~Kb}$ is required for whole genome association studies, giving a total requirement of 22,915 informative SNPs (MAF > 0.05) in the analysed lines. The high linkage disequilibrium between distant SNP pairs could be produced in some chromosomes by errors in the marker distance and position and in other cases by selection. Nevertheless, to confirm the last hypothesis a detailed study would be necessary of the regions where these SNPs are found.

Keywords: Linkage Disequilibrium, Haplotype Blocks, SNP, pig

\footnotetext{
${ }^{1}$ Article written in the Animal Science journal format
} 


\section{INTRODUCTION}

There has been a considerable increase in the molecular information available. The pig genome has been sequenced (www.ensembl.org/sus_scrofa) and the number of identified SNPs markers is growing fast. SNP genotyping will allow for "whole genome association trials" and discovery of many significant associations (Rothschild, et al., 2007), which are the basic information to perform genomic selection. A successful association analysis and consequent genomic selection depend on the marker density which is determined by the linkage disequilibrium (LD) extent across the genome (Khatkar, et al., 2008).

The LD is a nonrandom association between alleles at different loci. These allelic associations are mainly due to physical proximity but are also influenced by population history and evolutionary forces (Khatkar, et al., 2008). The influence of the population history on LD extent results in differences in this measurement between populations and consequently in the effectiveness of genome association studies.

The LD tends to decrease over large distances; nevertheless distant SNPs pairs might be in complete LD. In addition, tremendous differences can occur in the extent of LD from one genomic region to another (Wall and Pritchard, 2003). Despite this apparent complexity of the observed LD patterns, some studies have demonstrated that the LD is organized in discrete blocks of haplotypes that show high LD, separated by putative hot spots of recombination (Daly, et al., 2001; Ardlie, et al., 2002; Jeffreys, et al., 2001). Thus, the LD is often discontinuous and produces haplotypic profiles across the genome because of the variation in local recombination rates, mutation rates and genetic hitchhiking (Ardlie, et al., 2002).

The haplotype structure has important implications for association mapping and genomic selection because it makes it possible to select a set of SNPs that label the haplotype-block, which is a rational way to choose SNPs (Johnson, et al., 2001).

Du et al. (2007) used 4,500 SNPs markers and 6,000 pigs and observed, in the studied populations, that for SNPs pairs 3 centiMorgan $(\mathrm{cM})$ apart the average $\mathrm{r}^{2}$ was equal to 0.1. Amaral et al. (2008) genotyped three genomic regions using 371 SNP markers in several pig breeds. These authors reported that the LD extended up to $2 \mathrm{cM}$ in European breeds and up to $0.05 \mathrm{cM}$ in Chinese breeds and they also observed that the European breeds have larger haplotype blocks (>400kb) than the Chinese $(10 \mathrm{~kb})$. 
The present paper presents linkage disequilibrium and haplotype block structure in six commercial pig lines.

\section{MATERIALS AND METHODS}

\section{Data and haplotype reconstruction}

The data consisted of 2050 animals from commercial pig sire lines $(1, \mathrm{n}=1008$; 2, $\mathrm{n}=316$ and $5, \mathrm{n}=241)$ and dam lines $(4, \mathrm{n}=208 ; 6, \mathrm{n}=108$ and $3, \mathrm{n}=169)$ that were genotyped using the Illumina Porcine SNP60K Beadchip. The marker position used was derived from Build 10, avaible at http://www.animalgenome.org/repository/pig/. Markers with minor allele frequency (MAF) $<0.05$ and/or with P-value for HardyWeinberg equilibrium (HWE) $<0.001$ were discarded. This editing resulted in an average of 34,021 useful SNPs for each line which were used for further analysis.

\section{Measure of LD}

The correlation of gene frequencies $\left(\mathrm{r}^{2}\right)$ (Hill and Robertson,1968) was used as LD measure and it is defined as:

$$
r^{2}=\frac{D_{i j}^{2}}{p_{1} p_{2} q_{1} q_{2}}
$$

where, $D_{i j}=P_{i j}-p_{i} q_{j}$, is the LD measure purposed by Lewontin (1964), being $P_{i j}$ the observed frequency of the haplotype that consists of alleles $\mathrm{i}$ and $\mathrm{j} ; p_{i}$ the frequency of the allele $\mathrm{i}$ and $q_{j}$ the frequency of the allele $\mathrm{j}$ and $p_{1} p_{2} q_{1} q_{2}$ is the product of the four allele frequencies at the two loci.

The $\mathrm{r}^{2}$ was calculated using the Haploview v. 4.2 software (Barrett, et al., 2005) for every SNP pair and the R v.2.10.1 software was used to edit the Haploview outcome and construct LD graphics.

\section{Haplotype blocks}

$D^{\prime}$ (Lewontin, 1964) was used as LD measurement to define the blocks and for any two biallelic loci it is defined as:

$$
D^{\prime}=\sum_{i=1}^{2} \sum_{j=2}^{2} p_{i} q_{j} \frac{\left|D_{i j}\right|}{D_{\max }}
$$


where,

$$
D_{\text {max }}=\left\{\begin{array}{l}
\min \left[p_{i} q_{j},\left(1-p_{i}\right)\left(1-q_{j}\right)\right] \text { if } D_{i j}<0 \\
\min \left[p_{i}\left(1-q_{j}\right),\left(1-p_{i}\right) q_{j}\right] \text { if } D_{i j}>0
\end{array}\right.
$$

The haplotype blocks were estimated using the algorithm suggested by Gabriel et al. (2002). It considers that a pair of SNPs is in strong LD when the upper 95\% confidence bound of $D^{\prime}$ is between 0.7 and 0.98 . For these authors the haplotype block is a region over which a very small proportion (5\%) of comparisons among informative SNP pairs show strong evidence of historical recombination, and the term "strong evidence for historical recombination" pairs for which the upper confidence bound on D' is less than 0.9. Genotypes were inserted into Haploview v. 4.2 (Barret, et al., 2005) to calculate LD statistics and construct the haplotype blocks.

The average block size was compared among the six lines, and between sire (1, 2 and 5) and sow (3, 4 and 6) lines in each chromosome using the PROC MIXED procedure from SAS v. 9.1 following the model:

$$
Y_{i j}=\mu+L_{i}+b\left(G_{i j}-\bar{G}\right)+\varepsilon_{i j}
$$

where, $\mathrm{Y}_{\mathrm{ij}}$ is the observed block size; $\mu$ is the general constant; $L_{i}$ is the ith level of genetic group $i=1,2,3,4,5$ or 6 ; $b$ is the linear regression coefficient of the block size in function of the number of SNPs of the block $j$ and genetic group $i$ and $\mathrm{G}_{\mathrm{ij}}$ is the number of SNPs of block $j$ and genetic group $i$ and $\overline{\mathrm{G}}$ the average number of SNPs. $\varepsilon_{i j}$ is the random error, normally and independent distributed.

\section{RESULTS}

\section{Data description}

Each pig line was genotyped for 41,785 SNPs. On average, 34,021 SNPs remained for filtering on MAF $(\geq 0.05)$ and HWE $(\mathrm{P}>0.001)$ and they had an overall MAF mean of 0.285 . The number of SNPs on the different lines is summarised in Table1. It ranged from 32,706 on line 4 to 34,937 on line 6 . There were small differences in the number of SNPs after filtering and average MAF for each line in every chromosome (see Data Supplements). 
Table 1: Number of animals, the final number of SNPs used, average MAF and average distance between SNPs for each line

\begin{tabular}{rcccc}
\hline Line & $\begin{array}{c}\text { Number of } \\
\text { animals }\end{array}$ & $\begin{array}{c}\text { Final number } \\
\text { of SNPs }\end{array}$ & $\begin{array}{c}\text { Average } \\
\text { MAF }\end{array}$ & $\begin{array}{c}\text { Average distance } \\
\text { between SNPs }\end{array}$ \\
\hline 1 & 1,008 & 34138 & 0.279 & 70.481 \\
2 & 316 & 33081 & 0.286 & 72.733 \\
3 & 169 & 34438 & 0.289 & 69.283 \\
4 & 208 & 32706 & 0.278 & 73.567 \\
5 & 241 & 34828 & 0.291 & 69.085 \\
6 & 108 & 34937 & 0.285 & 68.869 \\
\hline
\end{tabular}

\section{Linkage Disequilibrium}

In theory, the linkage disequilibrium is higher in short distances and it decreases when the distance between markers increases. Nevertheless, a different behaviour was observed in chromosome 1 for all lines. Figure 1 shows high LD between distant SNP pairs in similar regions for all studied lines. Chromosomes 4, 5, 7, 9, 11, 12, 13, 14, 15 and 16 performed similarly, at a lesser intensity (Data Supplements). Figure 2 shows the LD behaviour in chromosome 2. There were differences in the LD decrease across the lines, the $\mathrm{r}^{2}$ (LD measure) was particularly higher between distant SNPs in lines 1 and 6 . Chromosome 3 (figure 3 ) has a linkage disequilibrium decrease comparable to the theory, the same was observed in chromosomes 6, 8 and 17 (Data Supplements).

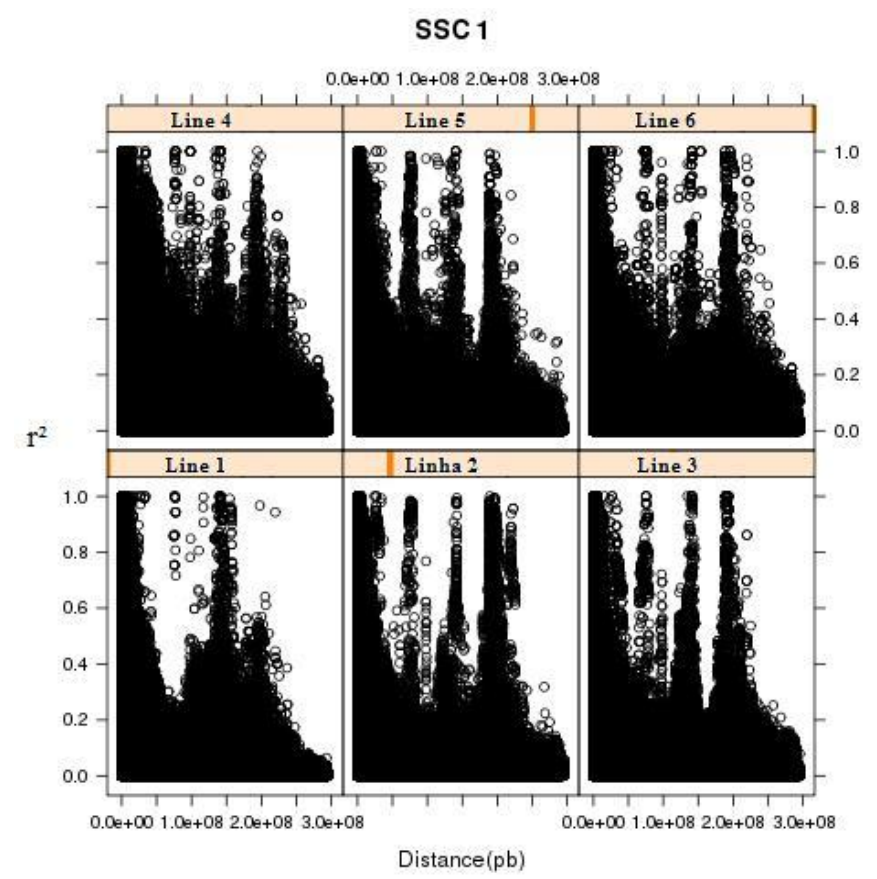

Figure 1

Linkage Disequilibrium between SNP pairs in relation to physical distance between SNPs in pig chromosome 1 for six commercial lines. 


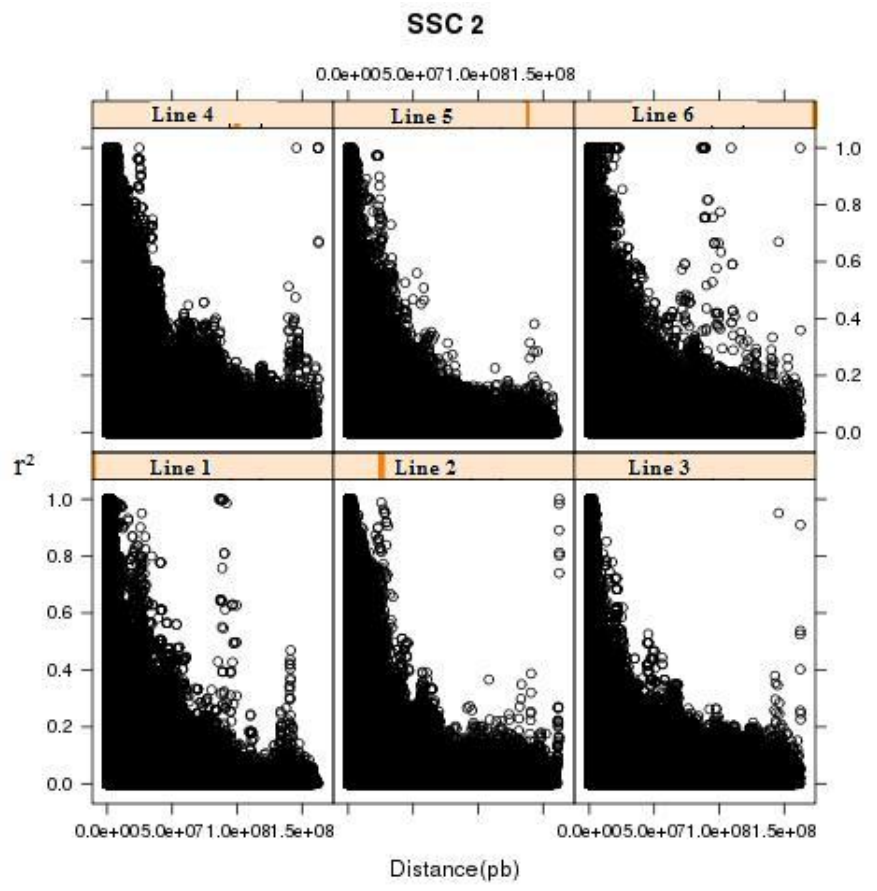

Figure 2

Linkage Disequilibrium $\left(\mathrm{r}^{2}\right)$ between SNP pairs in relation to physical distance between SNPs in pig chromosome 2 for six commercial lines.

$\mathrm{SSC}_{3}$

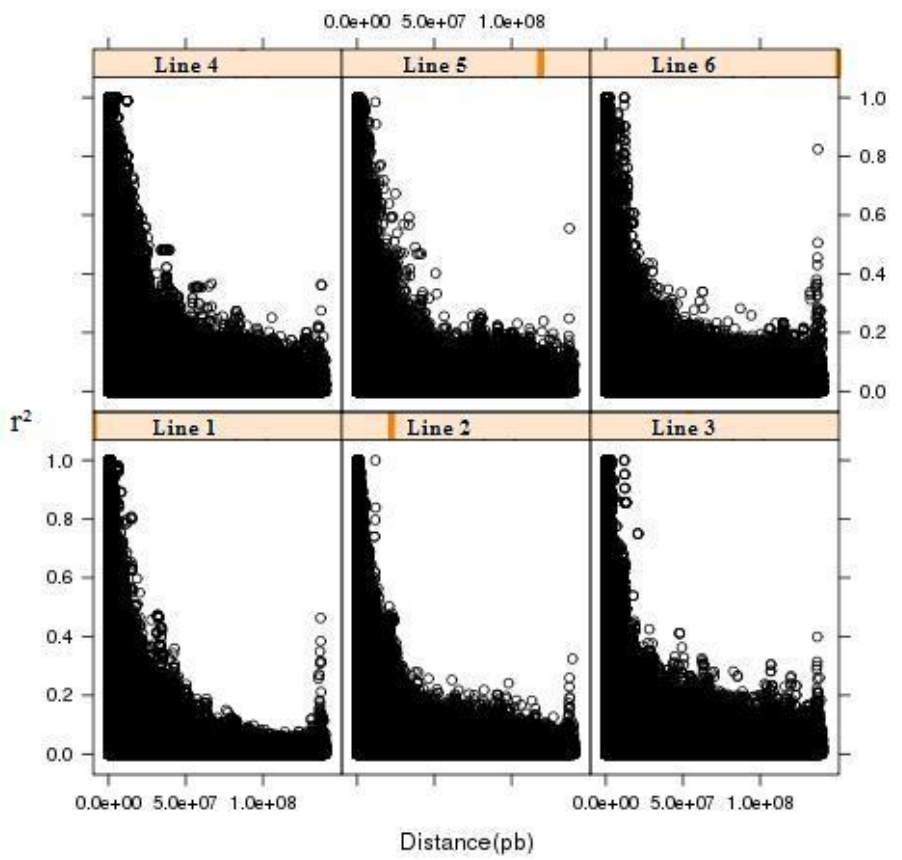

Figure 3

Linkage Disequilibrium $\left(\mathrm{r}^{2}\right)$ between SNP pairs in relation to physical distance between SNPs in pig chromosome 3 for six commercial lines.

Figure 4 shows the average correlation between gene frequencies $\left(r^{2}\right)$ in different marker distances for all lines. As expected, LD as a function of distance declined 
rapidly. It can be observed that all lines presented similar average $r^{2}$ in the different distances.

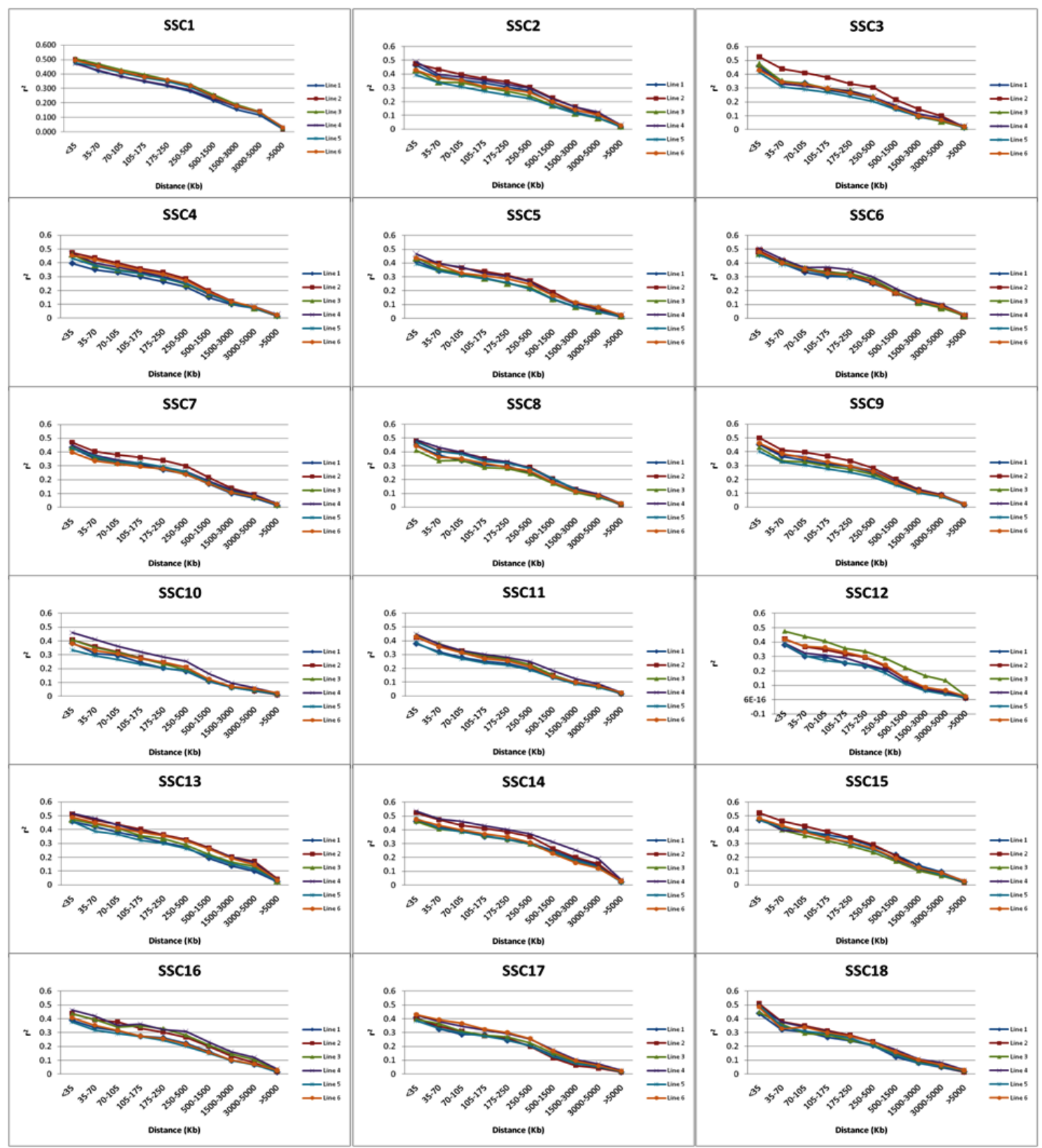

Figure 4

Average $\mathrm{r}^{2}$ across lines at different marker distance for all chromosomes

\section{Haplotype block structure}

Information about haplotype blocks is critical for association studies. The number of haplotype blocks in all autosomes, the number of SNPs captured by the blocks and the proportion of captured SNPs for each line are shown in Table 2. The number of haplotype blocks ranged from 3,917 on line 1 to 3,343 on line 6 and the 
proportion of the genome captured by haplotype blocks ranged from $46.98 \%$ on line 4 to $36.76 \%$ on line 5 . Line 1 had the highest number of SNPs captured by blocks $(21,298)$, but line 4 had the highest proportion $(63.87 \%)$ of captured SNPs in relation to the SNPs used. Line 5 had the lowest number $(19,156)$ and proportion $(55.00 \%)$ of captured SNPs. This descriptive analysis by each autossome was done and is exhibited in Data Supplements.

In general, the number of blocks differed between lines and chromosome, only the SSC9 the lines 3 and 5 had the same number of blocks (265) but they differed in the number of SNPs in the blocks and average block size. The same occurred with lines 2 and 4 and 5 and 6 on autossome 10 and on autossome 16 with lines 3 and 4 . Smaller or higher block size did not predominate in a specific line, the average block size depended on the line and chromosome. Generally, all lines and chromosomes had a higher standard deviation regarding block size (Data Supplements).

Figure 5 illustrates the block size frequency considering all autosomes. The six lines show a higher frequency of blocks with less than $50 \mathrm{~Kb}$ and blocks with more than $800 \mathrm{~Kb}$ occur at low frequency in all lines.

Table 2: Total number of blocks, genome proportion captured by haplotype blocks, total number of SNPs in the haplotype blocks, proportion of the used SNPs captured by haplotype blocks, average number of SNPs per block and average block size.

\begin{tabular}{|c|c|c|c|c|c|c|}
\hline Line & $\begin{array}{l}\text { Total } \\
\text { Number } \\
\text { of } \\
\text { blocks }\end{array}$ & $\begin{array}{c}\text { Genome } \\
\text { proportion } \\
\text { captured by } \\
\text { haploblocks }(\%)\end{array}$ & $\begin{array}{c}\text { Total } \\
\text { number of } \\
\text { SNPs in the } \\
\text { haploblock } \\
\text { s } \\
\end{array}$ & $\begin{array}{l}\text { Proportion of the } \\
\text { used SNPs } \\
\text { captured by } \\
\text { haploblocks (\%) }\end{array}$ & $\begin{array}{l}\text { Average } \\
\text { number } \\
\text { of SNP } \\
\text { per block }\end{array}$ & $\begin{array}{l}\text { Average } \\
\text { block } \\
\text { Size } \\
(\mathrm{Kb})\end{array}$ \\
\hline 1 & 3,917 & 43.94 & 21,298 & 62.39 & 5.44 & 269.91 \\
\hline 2 & 3,515 & 43.25 & 20,420 & 61.73 & 5.81 & 296.04 \\
\hline 3 & 3,582 & 41.77 & 20,196 & 58.15 & 5.64 & 280.61 \\
\hline 4 & 3,370 & 46.98 & 20,890 & 63.87 & 6.20 & 335.43 \\
\hline 5 & 3,726 & 36.76 & 19,156 & 55.00 & 5.14 & 237.43 \\
\hline 6 & 3,343 & 42.71 & 20,364 & 58.29 & 6.09 & 307.42 \\
\hline
\end{tabular}



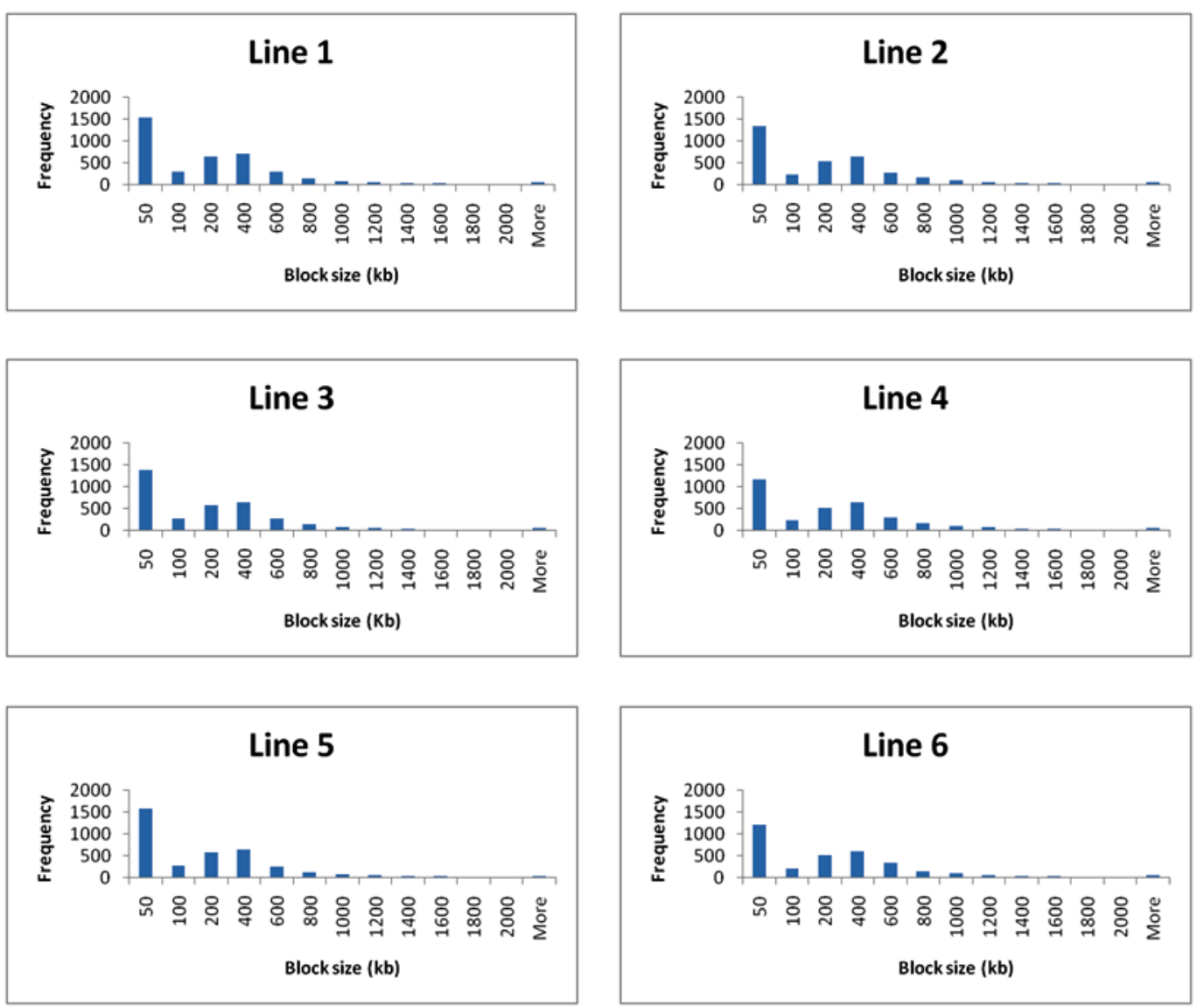

Figure 5

Block Size frequency in six pig lines considering all autossomes.

Table 1 shows that there were small dissimilarities in SNP density between lines; therefore to eliminate these differences the lines were compared using the number of SNP per block as covariate. The average block size of all lines was compared using the PROC MIXED procedure of SAS v.9.1. Figure 6 shows the comparison results considering all autossomes. Only the contrasts between lines 4 and 5 and 4 and 6 were significant $(\mathrm{P}<0.01)$. 


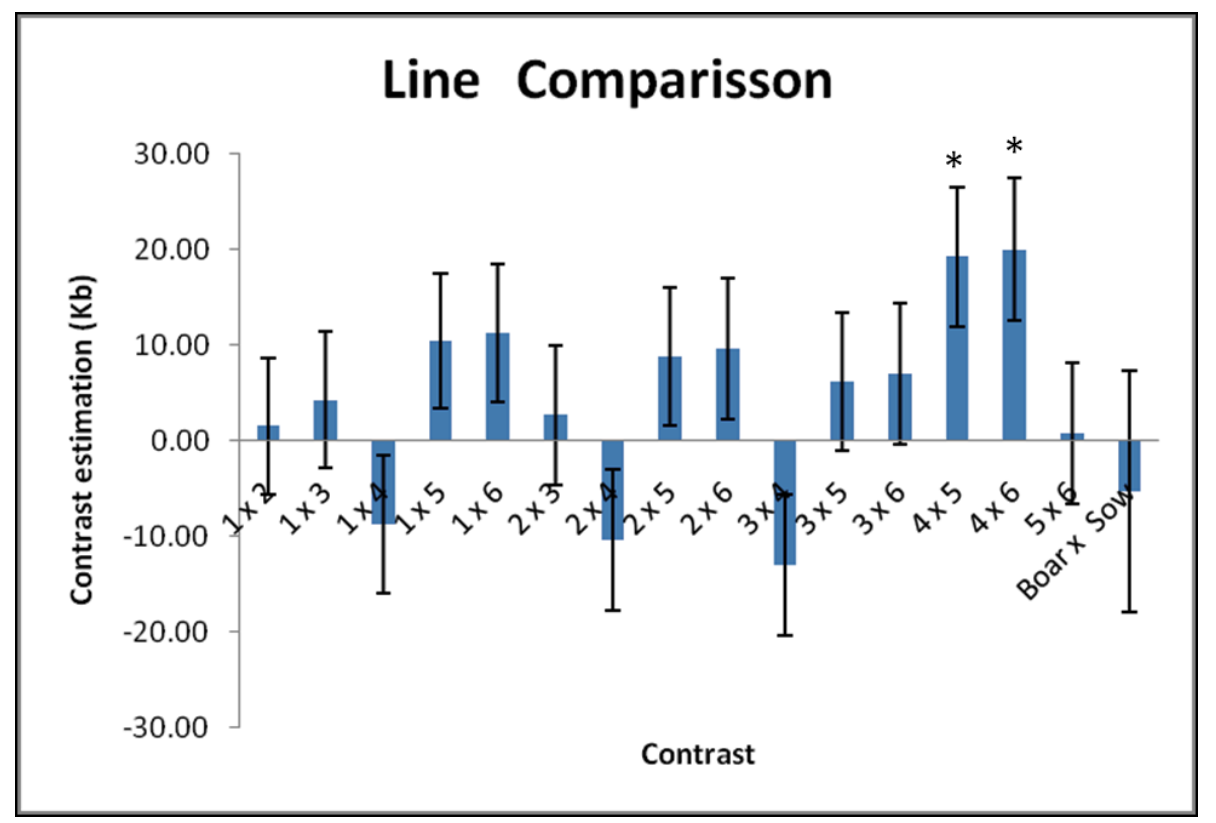

*Significant comparison ( $\mathrm{p}$-value $<0.05$ )

Figure 6

Contrasts between pig lines considering all autossomes evaluated using the t-test.

There was no common behaviour regarding average block size in all autossomes (Data Supplements), so it was important to make a line comparison by chromosome. The significant line comparisons by chromosome are presented in Table 3 . The average block size adjusted for number of SNPs in the blocks for each line by autossome and all comparisons between lines are shown in the Data Supplements. 
Table 3: Contrast estimate, standard error and P-value of the significant line comparisons by autossome.

\begin{tabular}{lcccc}
\hline Autossome & Contrast & $\begin{array}{c}\text { Contrast } \\
\text { Estimate }\end{array}$ & $\begin{array}{c}\text { Standard } \\
\text { Error }\end{array}$ & P-value \\
\hline 1 & 3 vs 5 & 45.731 & 25.028 & 0.068 \\
1 & 3 vs 6 & 41.908 & 25.077 & 0.095 \\
\hline 2 & 4 x 6 & 61.174 & 31.539 & 0.053 \\
\hline 3 & 1 vs 5 & 33.650 & 20.178 & 0.096 \\
3 & 3 vs 5 & 36.148 & 20.413 & 0.077 \\
\hline 5 & 1 vs 4 & -49.159 & 25.067 & 0.050 \\
5 & 2 vs 4 & -46.215 & 24.876 & 0.063 \\
5 & 4 vs 6 & 47.498 & 25.617 & 0.064 \\
\hline 7 & 3 vs 4 & -45.122 & 22.748 & 0.048 \\
7 & 4 vs 6 & 37.591 & 22.666 & 0.097 \\
\hline 9 & 1 vs 3 & 37.622 & 18.857 & 0.046 \\
9 & 1 vs 5 & 39.640 & 18.861 & 0.036 \\
9 & 3 vs 6 & -35.140 & 19.931 & 0.078 \\
9 & 5 vs 6 & -37.158 & 19.966 & 0.063 \\
\hline 10 & 4 vs 5 & 45.977 & 23.889 & 0.055 \\
\hline 15 & 1 vs4 & -79.789 & 41.770 & 0.056 \\
\hline 18 & 2 vs 3 & 44.580 & 19.738 & 0.024 \\
18 & 3 vs 5 & -49.339 & 19.895 & 0.013 \\
18 & 3 vs 6 & -33.225 & 19.477 & 0.089 \\
18 & Boar vs Sow & 70.509 & 33.887 & 0.038 \\
\hline & & & & \\
\hline
\end{tabular}

There were significant block size differences in autossomes 1, 2, 3, 5, 7, 9, 10, 15 and 18 (Table 3). Autossomes 9 and 18 had the largest number of significant comparisons, and in chromosome 18 the lines 2, 5 and 6 had greater block size than line 3 , in addition the contrast in this chromosome between boar lines (1,2 and 5) and sow lines (3, 4 and 6) was significant. A similar situation was observed in chromosome 5 where lines 1, 2 and 6 had smaller block sizes than line 4 .

\section{DISCUSSION}

The LD extent within a population determines the number of markers that will be required for successful association mapping and genomic selection. The major attraction of haplotype block estimation is the idea that most of the genetic variation is captured by common haplotypes and a small number of SNPs (tag SNPs) can be used to 
characterize the block. This report presents an LD analysis of six pig commercial lines covering all autossomes.

The number of genotyped animals diverges considerable among the lines, and line 1 had practically half of the genotyped animals (1008). It is well known that $\mathrm{D}^{\prime}$ is inflated with small sample sizes as demonstrated by Bohmanova et al. (2010), but the influence of this factor on the haplotype block estimation is reduced, since in the Gabriel et al. (2002) approach a narrow D' confidence bound is used. In addition, the correlation of gene frequencies $\left(\mathrm{r}^{2}\right)$ was used as linkage disequilibrium measurement to avoid the influence of small sample size and lower allele frequency, since it is considered a more robust linkage disequilibrium appraisal than D' (Du, et al., 2007; Johnson, et al., 2001; Amaral, et al., 2008; Bohmanova, et al., 2010).

In theory, the concept of linkage disequilibrium is quite simple; it refers to the nonrandom segregation of markers that are closely linked. The expected behaviour is to observe a decrease in the LD with increase in distance, consequently high levels of linkage disequilibrium occur between SNPs in close proximity and a lower LD is expected for distant SNP pairs. However, a range of factors affect the recombination measurement such as genetic drift, demographic population history, selection and other factors which make the linkage disequilibrium highly variable even between closely linked markers (Ardlie, et al., 2002; Kruglyak, 1999; Pritchard and Przeworski, 2001).

Although a decrease in the LD with increase in distance was expected and observed in some chromosomes (3, 6, 8 and 17), high linkage disequilibrium was observed between SNPs at large distances for all lines in chromosomes 1, 4, 5, 7, 9, 10, $12,13,14,15$ and 16 . It could be caused by the many factors that affect the LD as cited above. Nevertheless, the fact that high LD was observed in all the different lines studied leads us to suppose that it was caused by the accuracy of the genome assembly (Sscrofa10). Thus, the LD peaks observed in some chromosomes could be caused by mistakes in the order and distance between markers. The same problem was cited by Uimari and Tapio (2011), in a LD study using Sscrofa 9.

It is known that these lines have been submitted to diverse selection objectives mainly sire (1, 2 and 5) and sow lines (3,4 and 6) and they had differences regarding effective population size factors, inbreeding ratio, crossing and others that can affect the LD. In chromosomes 2 and 18 high LD was observed between distant SNPs for some lines, that could be explained by any factor cited above. Nevertheless, maybe factors such as genetic drift and population demography could be discarded, because they are 
characteristic of each population, and in this case, the SSC 18 and SSC 2 showed a similar pattern for more than one line.

There are some important traits for the pig chain, that could be a selection objective for any line, that can make different pig lines present a similar LD behavior. In this way, the high linkage disequilibrium over markers at large distances could be explained by a selection effect. However, to confirm this hypothesis it would be necessary to identify which are the distant SNPs that are in linkage disequilibrium and to investigate the QTLs present at these regions.

In the current study marker pairs separated by $1500-3000 \mathrm{~Kb}$ had an average $\mathrm{r}^{2}$ of 0.12, which was similar to that reported by Du et al. (2007) for pigs that estimated an average $r^{2}$ of 0.1 in a distance of 3 cM. In cattle, Qanbari et al. (2010) reported an average $\mathrm{r}^{2}$ of 0.3 between markers distant $25 \mathrm{~kb}$ and Bohmanova et al. (2010) found an average $r^{2}$ of 0.2 between markers $40-60 \mathrm{~Kb}$ apart for North American Holstein cattle, both studies found lower $r^{2}$ than that reported in the present study. Uimari and Tapio (2011) reported an average $\mathrm{r}^{2}$ of 0.47 and 0.49 for Finnish Landrace and Finnish Yorkshire, respectively, for SNPs $30 \mathrm{~Kb}$ apart. In the present study, an average $\mathrm{r}^{2}$ of $0.43,0.47,0.45,0.47,0.42$ and 0.45 was observed for the lines $1,2,3,4,5$ and 6 , respectively for SNPs with less than $35 \mathrm{~Kb}$ apart.

An average $r^{2}$ above 0.3 was found for all lines in markers between $105-175 \mathrm{~Kb}$ distance. This level of LD is suitable for association studies and genomic selection and considering that the pig genome size is $2.41 \mathrm{~Gb}$ (www.ensembl.org/sus scrofa), it implies the use of 22,915 informative SNPs (MAF > 0.05) for whole genome studies.

The recommendation above is supported by Meuwissen et al. (2001) who reported in a simulation study that the required LD level for genomic selection was 0.2 ; Qanbari et al. (2010) considered that a threshold of 0.25 was a useful LD for association studies and Ardlie et al. (2002) defined an $r^{2}>1 / 3$ as high values of LD. In pigs, Du et al. (2007) recommended marker spacing between 0.1 and $1 \mathrm{cM}$ for whole association studies, in addition the authors considered an $\mathrm{r}^{2}$ of 0.3 as a threshold of "usable" LD for association studies.

In the current study, all the pig autossomes were included in the investigation with an average marker density of one SNP every $70.67 \mathrm{~Kb}$. The blocks covered on average $42.57 \%$ of the pig genome and included $59.91 \%$ of the used SNPs. These values were much higher than the coverage described by Qanbari et al. (2010) which 
found that the blocks covered $4.7 \%$ of the bovine genome and included only $8 \%$ of all SNPs.

Although the average block size was $287.81 \mathrm{~Kb}$, small blocks with less than 50 $\mathrm{Kb}$ predominated in the six evaluated pig lines. Amaral et al. (2008) analyzed three regions of the chromosomes 18 and 3 and observed that in Chinese pig breeds LD is mostly organized in blocks of up to $10 \mathrm{~Kb}$ and in European breeds the LD extents over haplotype blocks up to $400 \mathrm{~kb}$. Although these results diverged from the current study, it is complex to compare the outcome from these studies, since in Amaral et al. (2008) the investigation was limited to three high density marked regions.

LD studies from humans and cattle can be used to make inferences about pigs, since it was reported that haplotype block structure is conserved across mammals (Guryev, et al., 2006). Qanbari et al. (2010) used 40,854 SNPs covering the whole bovine genome and observed 712 haplotype blocks with an average size of $164 \mathrm{~Kb}$. Villa-Angulo et al. (2009) evaluated high density marker regions (on average one SNP per $4 \mathrm{~Kb}$ ) of the bovine genome and reported haplotype blocks with an overall mean size of $10.3 \mathrm{~Kb}$ across 19 breeds, which according to the authors was similar to the block size observed in humans. An average block size of 7.3, 13.2, and $16.3 \mathrm{~kb}$ were observed in three human populations when ten $500 \mathrm{~Kb}$ regions with a density of approximately one SNP every $5 \mathrm{~kb}$ were analyzed (International HapMap Consortium, 2005).

It was expected that the average block size in pigs would be higher than in humans because of the natural aspects of livestock, such as small effective number, selection, crossing and genetic drift which contribute to increase the block size. The comparison with cattle studies is complicated because they have diverse outcomes, as showed above.

Some differences in SNP density between the lines were observed in this study, which can influence their haplotype block pattern. As a result, the block size was compared using the number of SNPs per block as covariate, in order to eliminate the influence of the marker density on the block size.

In chromosome 18 line 3 had smaller block size than most of the analyzed lines (2, 5 and 6). It could not be caused by SNP density, MAF or numbers of genotyped animals because these measurements were similar to the other lines and no differences were observed for them. This difference is difficult to understand, it could be caused by a range of factors such as selection, genetic drift, inbreeding and population history and 
only an in-depth study of these haplotype blocks could give a better understanding of this divergence.

The significant differences between lines regarding block size are difficult to explain, because they could be caused by many factors. An investigation of the regions where the lines disagree regarding the haplotype blocks and their selection history might provide greater understanding of the significant differences and it would permit a solid explanation of this divergence.

\section{CONCLUSIONS}

According to the LD extent observed at this study, 22,915 informative SNPs $(\mathrm{MAF}>0.05)$ would be necessary for whole genome association studies in the present lines. The high linkage disequilibrium observed in some chromosomes between distant SNPs may be caused by mistakes in the position and distance of the SNP marker. In addition, for some chromosomes (SSC2 and SSC18), the high LD may be caused by selection; but a in-depth study on the regions where these SNPs are found would be necessary to confirm this hypothesis. A concrete explanation for the divergences in haplotype block size can be made only with a more detailed study of the blocks.

\section{LITERATURE CITED}

Amaral A. J., H. J. Megens, R. P. M. A. Crooijmans, H. C. M. Heuven, M. A. M. Groenen. 2008. Linkage disequilibrium decay and haplotype block structure in the pig. Genetics. 179:569-579.

Ardlie K. G., L. Kruglyak, M. Seielstad. 2002. Patterns of linkage disequilibrium in the human genome. Nat. Rev. Genet. 3:299-309.

Barrett J. C., B. Fry, J. Maller, M. J. Daly. 2005. Haploview: analysis and visualization of LD and haplotype maps. Bioinformatics. 21:263-5

Bohmanova J., M. Sargolzaei, F.S. Schenkel. 2010. Characteristics of linkage disequilibrium in North American Holsteins. BMC genomics. 11:421.

Daly M. J., J. D. Rioux, S. F. Schaffner, T. J. Hudson, E. S. Lander 2001. Highresolution haplotype structure in the human genome. Nature genetics, 29:229-233.

Du, F. X., A. C. Clutter and M. M. Lohuis. 2007. Characterizing linkage disequilibrium in pig populations. Int. J. Biol. Sci. 3:166-178. 
Ensembl - www.ensembl.org/sus_scrofa.

Gabriel S. B., S. F. Schaffner, H. Nguyen, J. M. Moore, J. Roy, B. Blumenstiel, J. Higgins, M. DeFelice, A. Lochner, M. Faggart, S. N. Liu-Cordero, C. Rotimi, A. Adeyemo, R. Cooper, R. Ward, E. S. Lander, M. J. Daly, D. Altshuler. 2002. The structure of haplotype blocks in the human genome. Science. 296:2225-9.

Guryev V., B. M. G. Smits, J. V. D. Belt, M. Verheul, N. Hubner, E. Cuppen. 2006. Haplotype Block Structure Is Conserved across Mammals. PLOS Genetics. 2:11111118.

Hill W. G and A. Robertson. 1968. Linkage disequilibrium in finite populations. Theoret. Appl. Genetics. 38:226-231.

International HapMap Consortium. 2005. A haplotype map of the human genome. Nature. 437:1299-1320.

Jeffreys A. J, L. Kauppi, R. Neumann. 2001. Intensely punctate meiotic recombination in the class II region of the major histocompatibility complex. Nature genetics. 29:217-222.

Johnson G. C. L., L. Esposito, B. J. Barratt, A.N. Smith, J. Heward, G. Di Genova, H. Ueda, H. J. Cordell, I. A. Eaves, F. Dudbridge, R. C. J. Twells, F. Payne, W. Hughes, S. Nutland, H. Stevens, P. Carr, E. Tuomilehto-Wolf, J. Tuomilehto, S. C. L. Gough, D. G. Clayton and J. A. Todd. 2001. Haplotype tagging for the identification of common disease genes. Nature genetics. 29:233-238.

Khatkar M. S., F. W. Nicholas, A. R. Collins, K. R. Zenger, J. Al Cavanagh, W. Barris, R. D. Schnabel, J. F. Taylor and H. W. Raadsma. 2008. Extent of genome-wide linkage disequilibrium in Australian Holstein-Friesian cattle based on a high-density SNP panel. BMC Genomics. 9:187.

Kruglyak L. 1999. Prospects for whole-genome linkage disequilibrium mapping of common disease genes. Nature genetics. 22:139-144.

Lewontin R. C. 1964. The Interaction of Selection and Linkage. I. General Considerations; Heterotic Models. Genetics, 49:49-67.

Meuwissen T. H. E., B. J. Hayes, M. E. Goddard. 2001. Prediction of Total Genetic Value Using Genome-Wide Dense Marker Maps. Genetics. 157:1819-1829.

Pig QTL database - www.animalgenome.org/cgi-bin/QTLdb/SS/index

Pritchard J.K., M. Przeworski. 2001.Linkage Disequilibrium in Humans: Models and Data. Am. J. Hum. Genet. 69:1-14. 
Qanbari S, E. C. G. Pimentel, J. Tetens, G. Thaller, P. Lichtner, A.R. Sharifi, H. Simianer. 2010. The pattern of linkage disequilibrium in German Holstein cattle. Animal Genetics. 41:346-356.

Rothschild M. F., Z. Hu, Z. Jiang. 2007. Advances in QTL mapping in pigs Int. J. Biol. Sci. 3:192-7.

SAS Institute Inc., SAS 9.1.3 Help and Documentation, Cary, NC: SAS Institute Inc., 2000-2004.

The R Foundation for Statistical Computing. 2009. R version 2.10.1

Uimari, P. and M. Tapio. 2011. Extent of linkage disequilibrium and effective population size in Finnish Landrace and Finnish Yorkshire pig breeds. J. Anim. Sci. 89:609-614.

Villa-angulo R., L. K. Matukumalli, C. A. Gill, J. Choi, C. P. Van Tassell, J. J. Grefenstette.2009. High-resolution haplotype block structure in the cattle genome. BMC Genetics. 13:1-13.

Wall J. D., J. K. Pritchard. 2003. Haplotype blocks and linkage disequilibrium in the human genome. Nat. Rev. Genet. 4:587-97. 


\section{DATA SUPPLEMENTS}

Table 1. Number of SNPs in the beginning of analysis, the final number of SNPs used, average MAF and average distance between SNPs by chromosome

\begin{tabular}{|c|c|c|c|c|}
\hline \multicolumn{5}{|c|}{ All Chromossomes } \\
\hline Line & $\begin{array}{l}\text { Initial number of } \\
\text { SNPs }\end{array}$ & $\begin{array}{c}\text { Final number of } \\
\text { SNPs }\end{array}$ & Average MAF & $\begin{array}{l}\text { Average distance } \\
\text { between SNPs }\end{array}$ \\
\hline 1 & 41,785 & 34,138 & 0.279 & 70.481 \\
\hline 2 & 41,785 & 33,081 & 0.286 & 72.733 \\
\hline 3 & 41,785 & 34,438 & 0.289 & 69.283 \\
\hline 4 & 41,785 & 32,706 & 0.278 & 73.567 \\
\hline 5 & 41,785 & 34,828 & 0.291 & 69.085 \\
\hline 6 & 41,785 & 34,937 & 0.285 & 68.869 \\
\hline \multicolumn{5}{|c|}{$\begin{array}{r}\mathrm{SSC} 1 \\
\end{array}$} \\
\hline Line & $\begin{array}{c}\text { Initial number of } \\
\text { SNPs }\end{array}$ & $\begin{array}{c}\text { Final number of } \\
\text { SNPs }\end{array}$ & Average MAF & $\begin{array}{c}\text { Average distance } \\
\text { between SNPs }\end{array}$ \\
\hline 1 & 5,386 & 4,183 & 0.269 & 70.812 \\
\hline 2 & 5,386 & 4,326 & 0.281 & 68.472 \\
\hline 3 & 5,386 & 4,054 & 0.285 & 73.066 \\
\hline 4 & 5,386 & 4,156 & 0.276 & 71.272 \\
\hline 5 & 5,386 & 4,404 & 0.303 & 67.259 \\
\hline 6 & 5,386 & 4,515 & 0.290 & 65.605 \\
\hline \multicolumn{5}{|c|}{$\mathrm{SSC} 2$} \\
\hline Line & $\begin{array}{l}\text { Initial number of } \\
\text { SNPs }\end{array}$ & $\begin{array}{l}\text { Final number of } \\
\text { SNPs }\end{array}$ & Average MAF & $\begin{array}{c}\text { Average distance } \\
\text { between SNPs }\end{array}$ \\
\hline 1 & 2,656 & 2,217 & 0.285 & 73.556 \\
\hline 2 & 2,656 & 2,168 & 0.291 & 75.219 \\
\hline 3 & 2,656 & 2,273 & 0.294 & 71.744 \\
\hline 4 & 2,656 & 2,078 & 0.278 & 78.477 \\
\hline 5 & 2,656 & 2,332 & 0.292 & 69.929 \\
\hline 6 & 2,656 & 2,362 & 0.285 & 69.041 \\
\hline \multicolumn{5}{|c|}{ SSC3 } \\
\hline Line & $\begin{array}{l}\text { Initial number of } \\
\text { SNPs }\end{array}$ & $\begin{array}{c}\text { Final number of } \\
\text { SNPs }\end{array}$ & Average MAF & $\begin{array}{c}\text { Average distance } \\
\text { between SNPs }\end{array}$ \\
\hline 1 & 2,238 & 1,750 & 0.260 & 81.483 \\
\hline 2 & 2,238 & 1,759 & 0.289 & 81.066 \\
\hline 3 & 2,238 & 1,898 & 0.279 & 75.129 \\
\hline 4 & 2,238 & 1,908 & 0.282 & 74.735 \\
\hline 5 & 2,238 & 1,977 & 0.289 & 72.127 \\
\hline 6 & 2,238 & 1,914 & 0.288 & 74.501 \\
\hline
\end{tabular}


Cont. Table 1. Number of SNPs in the beginning of analysis, the final number of SNPs used, average MAF and average distance between SNPs by chromosome

\begin{tabular}{|c|c|c|c|c|}
\hline \multicolumn{5}{|c|}{ SSC4 } \\
\hline Line & $\begin{array}{c}\text { Initial number of } \\
\text { SNPs }\end{array}$ & $\begin{array}{c}\text { Final number of } \\
\text { SNPs }\end{array}$ & Average MAF & $\begin{array}{c}\text { Average distance } \\
\text { between SNPs }\end{array}$ \\
\hline 1 & 2,964 & 2,552 & 0.279 & 54.274 \\
\hline 2 & 2,964 & 2,211 & 0.285 & 62.644 \\
\hline 3 & 2,964 & 2,435 & 0.290 & 56.881 \\
\hline 4 & 2,964 & 2,292 & 0.277 & 60.430 \\
\hline 5 & 2,964 & 2,456 & 0.305 & 56.395 \\
\hline 6 & 2,964 & 2,300 & 0.283 & 60.220 \\
\hline \multicolumn{5}{|c|}{ SSC5 } \\
\hline Line & $\begin{array}{l}\text { Initial number of } \\
\text { SNPs }\end{array}$ & $\begin{array}{c}\text { Final number of } \\
\text { SNPs }\end{array}$ & Average MAF & $\begin{array}{c}\text { Average distance } \\
\text { between SNPs }\end{array}$ \\
\hline 1 & 1,915 & 1,546 & 0.270 & 71.502 \\
\hline 2 & 1,915 & 1,590 & 0.291 & 69.524 \\
\hline 3 & 1,915 & 1,463 & 0.286 & 75.559 \\
\hline 4 & 1,915 & 1,453 & 0.261 & 76.079 \\
\hline 5 & 1,915 & 1,623 & 0.293 & 68.110 \\
\hline 6 & 1,915 & 1,565 & 0.278 & 70.634 \\
\hline \multicolumn{5}{|c|}{ SSC6 } \\
\hline Line & $\begin{array}{l}\text { Initial number of } \\
\text { SNPs }\end{array}$ & $\begin{array}{c}\text { Final number of } \\
\text { SNPs }\end{array}$ & Average MAF & $\begin{array}{c}\text { Average distance } \\
\text { between SNPs }\end{array}$ \\
\hline 1 & 2,411 & 2,050 & 0.294 & 76.834 \\
\hline 2 & 2,411 & 1,953 & 0.293 & 80.650 \\
\hline 3 & 2,411 & 2,070 & 0.293 & 76.092 \\
\hline 4 & 2,411 & 1,913 & 0.257 & 82.337 \\
\hline 5 & 2,411 & 1,989 & 0.285 & 79.191 \\
\hline 6 & 2,411 & 2,038 & 0.295 & 77.287 \\
\hline \multicolumn{5}{|c|}{$\begin{array}{r}\text { SSC7 } \\
\end{array}$} \\
\hline Line & $\begin{array}{l}\text { Initial number of } \\
\text { SNPs }\end{array}$ & $\begin{array}{c}\text { Final number of } \\
\text { SNPs }\end{array}$ & Average MAF & $\begin{array}{c}\text { Average distance } \\
\text { between SNPs }\end{array}$ \\
\hline 1 & 2,780 & 2,125 & 0.271 & 63.097 \\
\hline 2 & 2,780 & 2,203 & 0.287 & 60.863 \\
\hline 3 & 2,780 & 2,152 & 0.296 & 62.306 \\
\hline 4 & 2,780 & 2,070 & 0.271 & 64.774 \\
\hline 5 & 2,780 & 2,288 & 0.281 & 58.602 \\
\hline 6 & 2,780 & 2,419 & 0.280 & 55.429 \\
\hline
\end{tabular}


Cont. Table 1. Number of SNPs in the beginning of analysis, the final number of SNPs used, average MAF and average distance between SNPs by chromosome

\begin{tabular}{|c|c|c|c|c|}
\hline \multicolumn{5}{|c|}{ SSC8 } \\
\hline Line & $\begin{array}{c}\text { Initial number of } \\
\text { SNPs }\end{array}$ & $\begin{array}{c}\text { Final number of } \\
\text { SNPs }\end{array}$ & Average MAF & $\begin{array}{c}\text { Average distance } \\
\text { between SNPs }\end{array}$ \\
\hline 1 & 2,177 & 1,825 & 0.284 & 80.919 \\
\hline 2 & 2,177 & 1,652 & 0.288 & 89.393 \\
\hline 3 & 2,177 & 1,887 & 0.294 & 78.260 \\
\hline 4 & 2,177 & 1,634 & 0.272 & 90.377 \\
\hline 5 & 2,177 & 1,439 & 0.272 & 102.624 \\
\hline 6 & 2,177 & 1,834 & 0.288 & 80.522 \\
\hline \multicolumn{5}{|c|}{ SSC9 } \\
\hline Line & $\begin{array}{c}\text { Initial number of } \\
\text { SNPs }\end{array}$ & $\begin{array}{c}\text { Final number of } \\
\text { SNPs }\end{array}$ & Average MAF & $\begin{array}{c}\text { Average distance } \\
\text { between SNPs }\end{array}$ \\
\hline 1 & 2,578 & 2,074 & 0.284 & 73.322 \\
\hline 2 & 2,578 & 2,120 & 0.278 & 71.731 \\
\hline 3 & 2,578 & 2,264 & 0.284 & 67.169 \\
\hline 4 & 2,578 & 2,128 & 0.276 & 71.461 \\
\hline 5 & 2,578 & 2,279 & 0.302 & 66.727 \\
\hline 6 & 2,578 & 2,153 & 0.263 & 70.632 \\
\hline \multicolumn{5}{|c|}{$\mathrm{SSC10}$} \\
\hline Line & $\begin{array}{c}\text { Initial number of } \\
\text { SNPs }\end{array}$ & $\begin{array}{c}\text { Final number of } \\
\text { SNPs }\end{array}$ & Average MAF & $\begin{array}{c}\text { Average distance } \\
\text { between SNPs }\end{array}$ \\
\hline 1 & 1,299 & 1,100 & 0.278 & 73.278 \\
\hline 2 & 1,299 & 1,054 & 0.284 & 76.476 \\
\hline 3 & 1,299 & 1,084 & 0.287 & 74.360 \\
\hline 4 & 1,299 & 1,065 & 0.278 & 75.687 \\
\hline 5 & 1,299 & 1,137 & 0.291 & 70.894 \\
\hline 6 & 1,299 & 1,151 & 0.284 & 70.031 \\
\hline \multicolumn{5}{|c|}{$\mathrm{SSC} 11$} \\
\hline Line & $\begin{array}{l}\text { Initial number of } \\
\text { SNPs }\end{array}$ & $\begin{array}{c}\text { Final number of } \\
\text { SNPs }\end{array}$ & Average MAF & $\begin{array}{c}\text { Average distance } \\
\text { between SNPs }\end{array}$ \\
\hline 1 & 1,561 & 1,328 & 0.293 & 63.386 \\
\hline 2 & 1,561 & 1,226 & 0.286 & 68.660 \\
\hline 3 & 1,561 & 1,265 & 0.262 & 66.543 \\
\hline 4 & 1,561 & 1,163 & 0.283 & 72.379 \\
\hline 5 & 1,561 & 1,328 & 0.287 & 63.386 \\
\hline 6 & 1,561 & 1,278 & 0.268 & 65.866 \\
\hline
\end{tabular}


Cont. Table 1. Number of SNPs in the beginning of analysis, the final number of SNPs used, average MAF and average distance between SNPs by chromosome

\begin{tabular}{|c|c|c|c|c|}
\hline \multicolumn{5}{|c|}{ SSC12 } \\
\hline Line & $\begin{array}{c}\text { Initial number of } \\
\text { SNPs }\end{array}$ & $\begin{array}{c}\text { Final number of } \\
\text { SNPs }\end{array}$ & Average MAF & $\begin{array}{c}\text { Average distance } \\
\text { between SNPs }\end{array}$ \\
\hline 1 & 1,247 & 1,009 & 0.284 & 63.707 \\
\hline 2 & 1,247 & 1,024 & 0.294 & 62.773 \\
\hline 3 & 1,247 & 1,089 & 0.292 & 59.027 \\
\hline 4 & 1,247 & 1,071 & 0.277 & 60.019 \\
\hline 5 & 1,247 & 1,138 & 0.301 & 56.485 \\
\hline 6 & 1,247 & 1,074 & 0.307 & 59.851 \\
\hline \multicolumn{5}{|c|}{ SSC13 } \\
\hline Line & $\begin{array}{c}\text { Initial number of } \\
\text { SNPs }\end{array}$ & $\begin{array}{c}\text { Final number of } \\
\text { SNPs }\end{array}$ & Average MAF & $\begin{array}{c}\text { Average distance } \\
\text { between SNPs }\end{array}$ \\
\hline 1 & 2,966 & 2,315 & 0.279 & 91.962 \\
\hline 2 & 2,966 & 2,355 & 0.285 & 90.400 \\
\hline 3 & 2,966 & 2,416 & 0.285 & 88.118 \\
\hline 4 & 2,966 & 2,258 & 0.298 & 94.284 \\
\hline 5 & 2,966 & 2,526 & 0.298 & 84.280 \\
\hline 6 & 2,966 & 2,470 & 0.284 & 86.191 \\
\hline \multicolumn{5}{|c|}{ SSC14 } \\
\hline Line & $\begin{array}{l}\text { Initial number of } \\
\text { SNPs }\end{array}$ & $\begin{array}{c}\text { Final number of } \\
\text { SNPs }\end{array}$ & Average MAF & $\begin{array}{c}\text { Average distance } \\
\text { between SNPs }\end{array}$ \\
\hline 1 & 3,292 & 2,785 & 0.279 & 55.180 \\
\hline 2 & 3,292 & 2,661 & 0.290 & 57.752 \\
\hline 3 & 3,292 & 2,896 & 0.315 & 53.065 \\
\hline 4 & 3,292 & 2,653 & 0.300 & 57.926 \\
\hline 5 & 3,292 & 2,804 & 0.284 & 54.806 \\
\hline 6 & 3,292 & 2,685 & 0.291 & 57.235 \\
\hline \multicolumn{5}{|c|}{ SSC15 } \\
\hline Line & $\begin{array}{c}\text { Initial number of } \\
\text { SNPs }\end{array}$ & $\begin{array}{c}\text { Final number of } \\
\text { SNPs }\end{array}$ & Average MAF & $\begin{array}{c}\text { Average distance } \\
\text { between SNPs }\end{array}$ \\
\hline 1 & 2,270 & 1,945 & 0.286 & 78.535 \\
\hline 2 & 2,270 & 1,726 & 0.282 & 88.499 \\
\hline 3 & 2,270 & 1,810 & 0.271 & 84.392 \\
\hline 4 & 2,270 & 1,689 & 0.273 & 90.438 \\
\hline 5 & 2,270 & 1,805 & 0.266 & 84.626 \\
\hline 6 & 2,270 & 1,887 & 0.281 & 80.949 \\
\hline
\end{tabular}


Cont. Table 1. Number of SNPs in the beginning of analysis, the final number of SNPs used, average MAF and average distance between SNPs by chromosome

\begin{tabular}{|c|c|c|c|c|}
\hline \multicolumn{5}{|c|}{ SSC16 } \\
\hline Line & $\begin{array}{l}\text { Initial number of } \\
\text { SNPs }\end{array}$ & $\begin{array}{c}\text { Final number of } \\
\text { SNPs }\end{array}$ & Average MAF & $\begin{array}{c}\text { Average distance } \\
\text { between SNPs }\end{array}$ \\
\hline 1 & 1,554 & 1,320 & 0.285 & 65.149 \\
\hline 2 & 1,554 & 1,198 & 0.298 & 71.783 \\
\hline 3 & 1,554 & 1,263 & 0.293 & 55.374 \\
\hline 4 & 1,554 & 1,227 & 0.281 & 70.087 \\
\hline 5 & 1,554 & 1,332 & 0.296 & 64.562 \\
\hline 6 & 1,554 & 1,249 & 0.294 & 68.852 \\
\hline \multicolumn{5}{|c|}{ SSC17 } \\
\hline Line & $\begin{array}{c}\text { Initial number of } \\
\text { SNPs }\end{array}$ & $\begin{array}{c}\text { Final number of } \\
\text { SNPs }\end{array}$ & Average MAF & $\begin{array}{c}\text { Average distance } \\
\text { between SNPs }\end{array}$ \\
\hline 1 & 1,399 & 1,108 & 0.271 & 62.646 \\
\hline 2 & 1,399 & 1,083 & 0.274 & 64.092 \\
\hline 3 & 1,399 & 1,183 & 0.277 & 58.675 \\
\hline 4 & 1,399 & 1,089 & 0.278 & 63.739 \\
\hline 5 & 1,399 & 1,190 & 0.291 & 58.329 \\
\hline 6 & 1,399 & 1,165 & 0.297 & 59.581 \\
\hline \multicolumn{5}{|c|}{ SSC18 } \\
\hline Line & $\begin{array}{l}\text { Initial number of } \\
\text { SNPs }\end{array}$ & $\begin{array}{c}\text { Final number of } \\
\text { SNPs }\end{array}$ & Average MAF & $\begin{array}{c}\text { Average distance } \\
\text { between SNPs }\end{array}$ \\
\hline 1 & 1,092 & 906 & 0.294 & 66.248 \\
\hline 2 & 1,092 & 772 & 0.260 & 77.747 \\
\hline 3 & 1,092 & 936 & 0.299 & 64.125 \\
\hline 4 & 1,092 & 859 & 0.269 & 69.873 \\
\hline 5 & 1,092 & 781 & 0.259 & 76.851 \\
\hline 6 & 1,092 & 878 & 0.268 & 68.361 \\
\hline
\end{tabular}




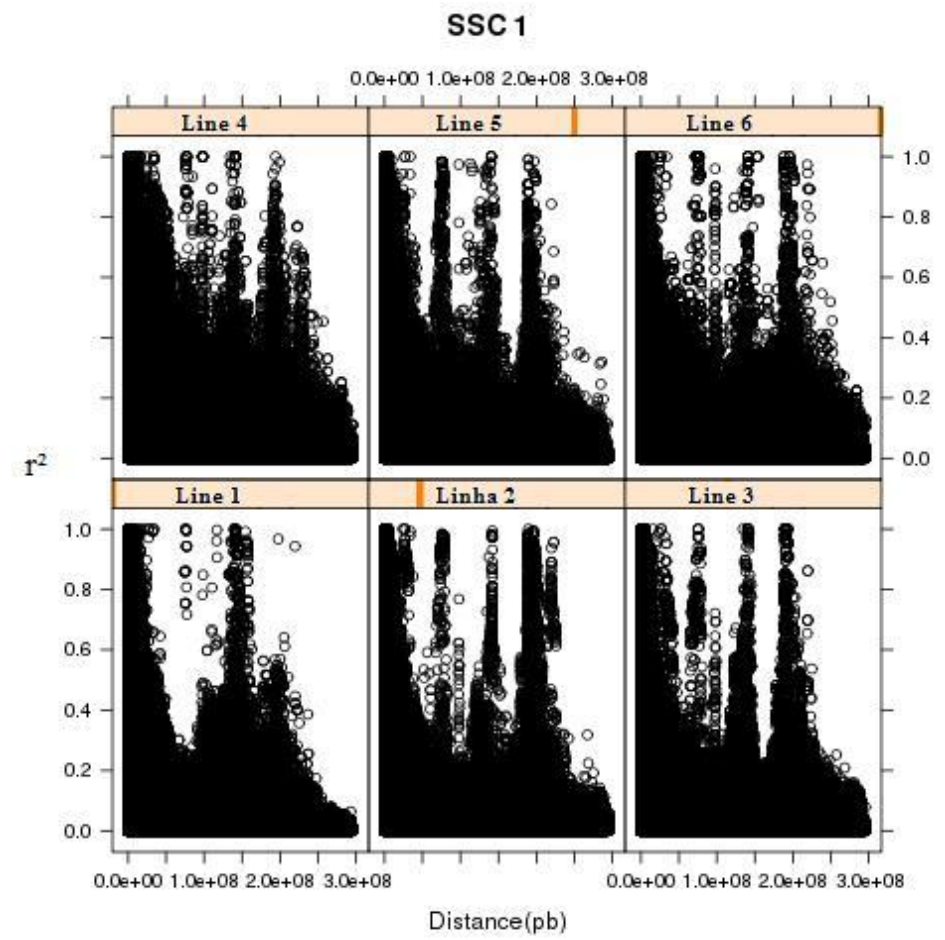

Figure 1

Linkage Disequilibrium between SNP pairs in relation to physical distance between loci in pig chromosome 1 for six commercial lines.

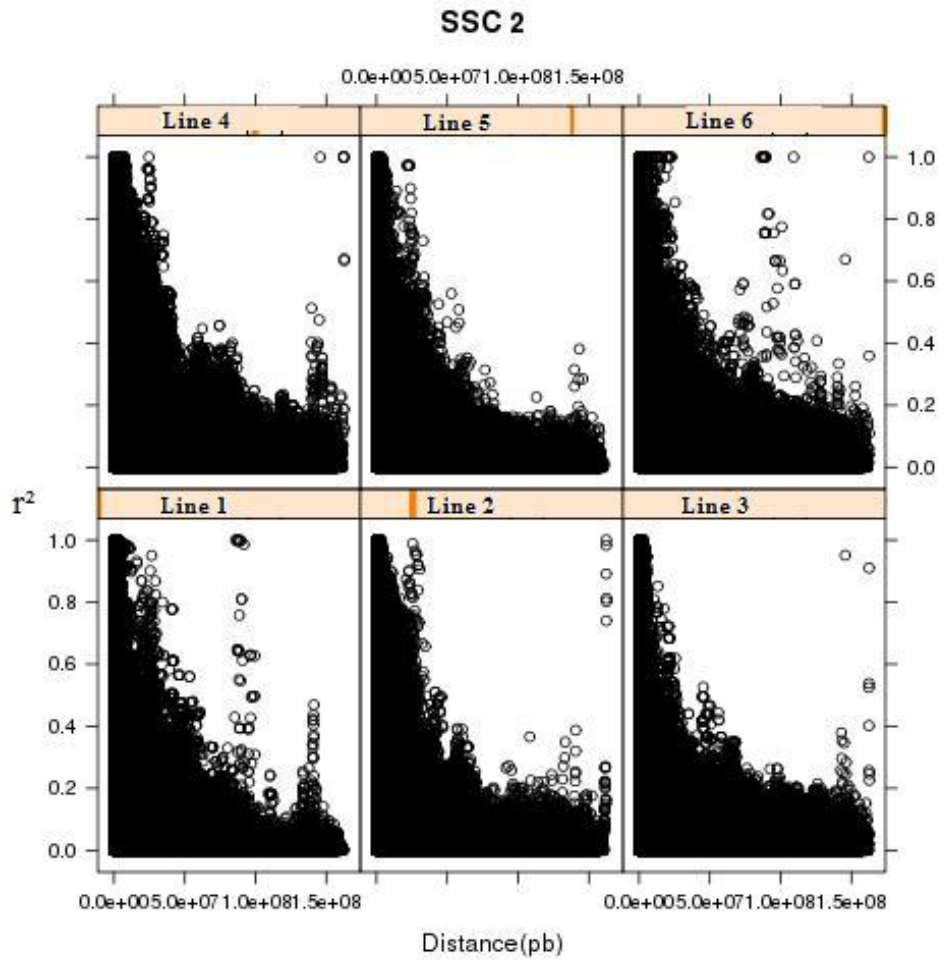

Figure 2

Linkage Disequilibrium between SNP pairs in relation to physical distance between loci in pig chromosome 2 for six commercial lines. 
$\operatorname{SSC} 3$

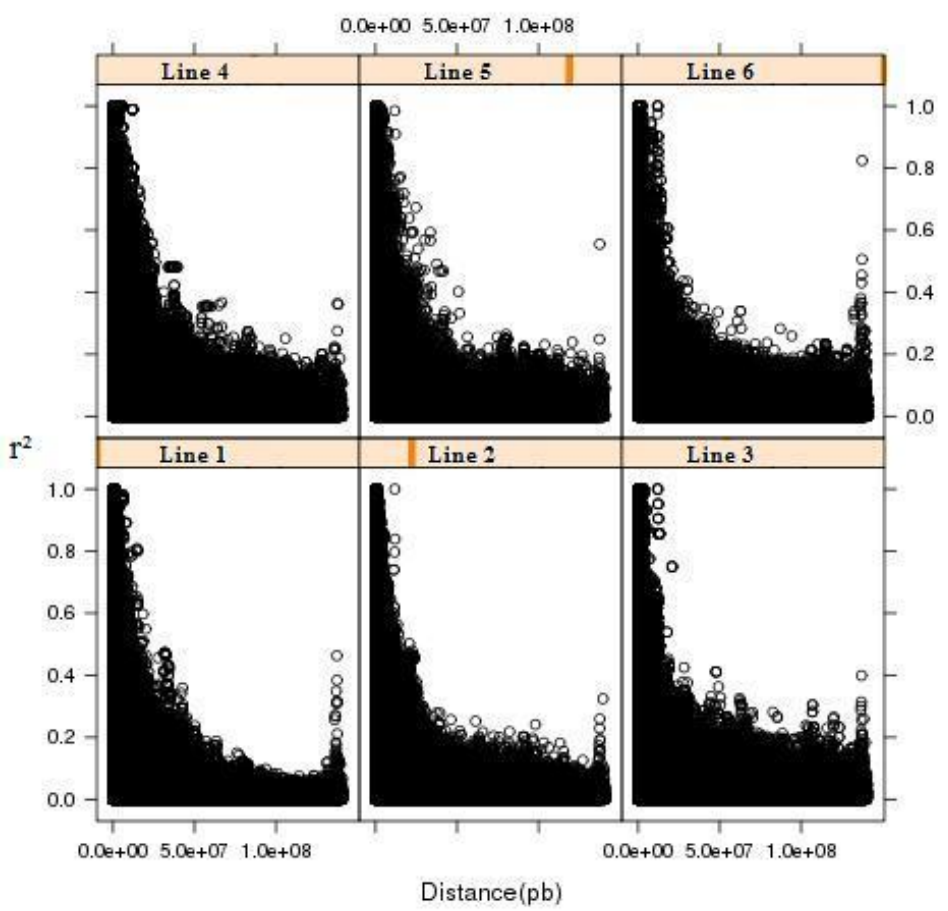

Figure 3

Linkage Disequilibrium between SNP pairs in relation to physical distance between loci in pig chromosome 3 for six commercial lines.

\section{$\operatorname{ssc} 4$}

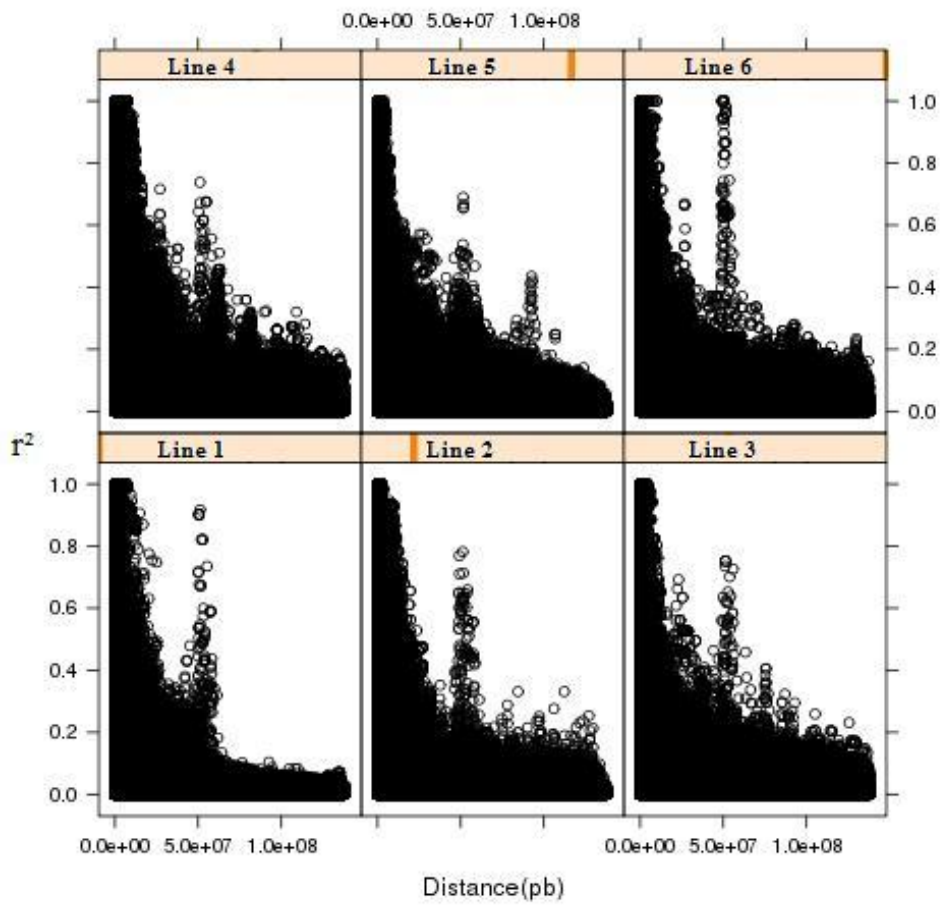

Figure 4

Linkage Disequilibrium between SNP pairs in relation to physical distance between loci in pig chromosome 4 for six commercial lines. 
$\operatorname{SSC} 5$

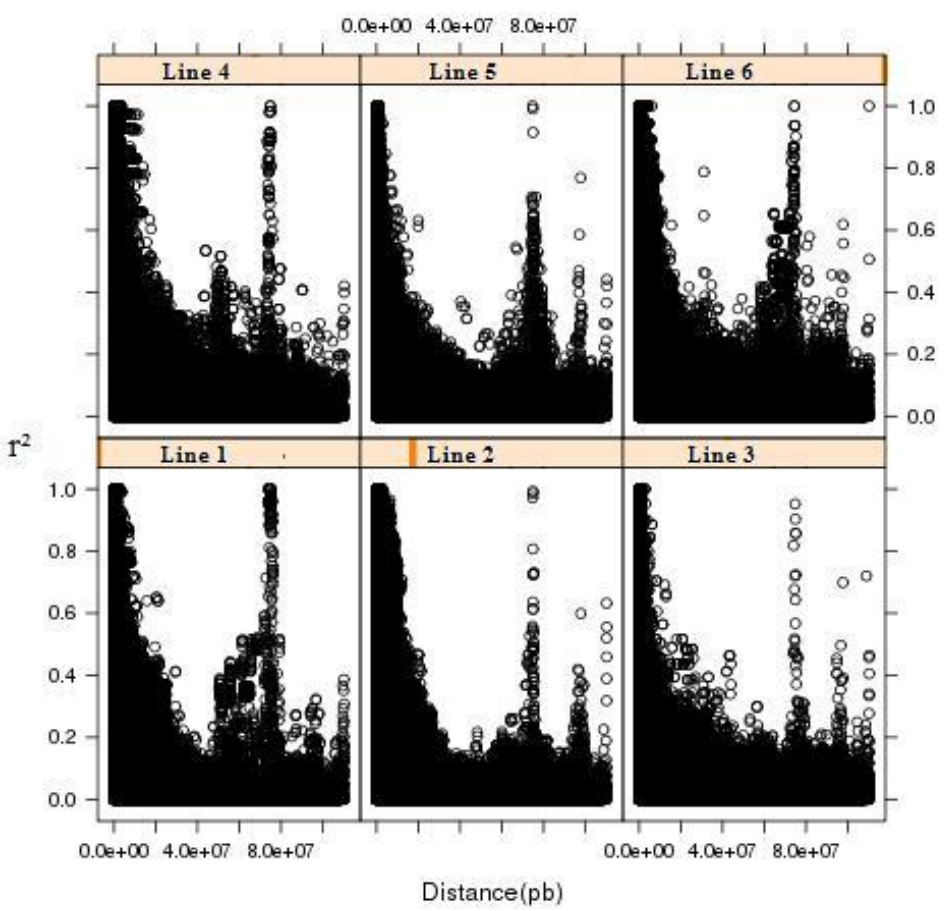

Figure 5

Linkage Disequilibrium between SNP pairs in relation to physical distance between loci in pig chromosome 5 for six commercial lines.

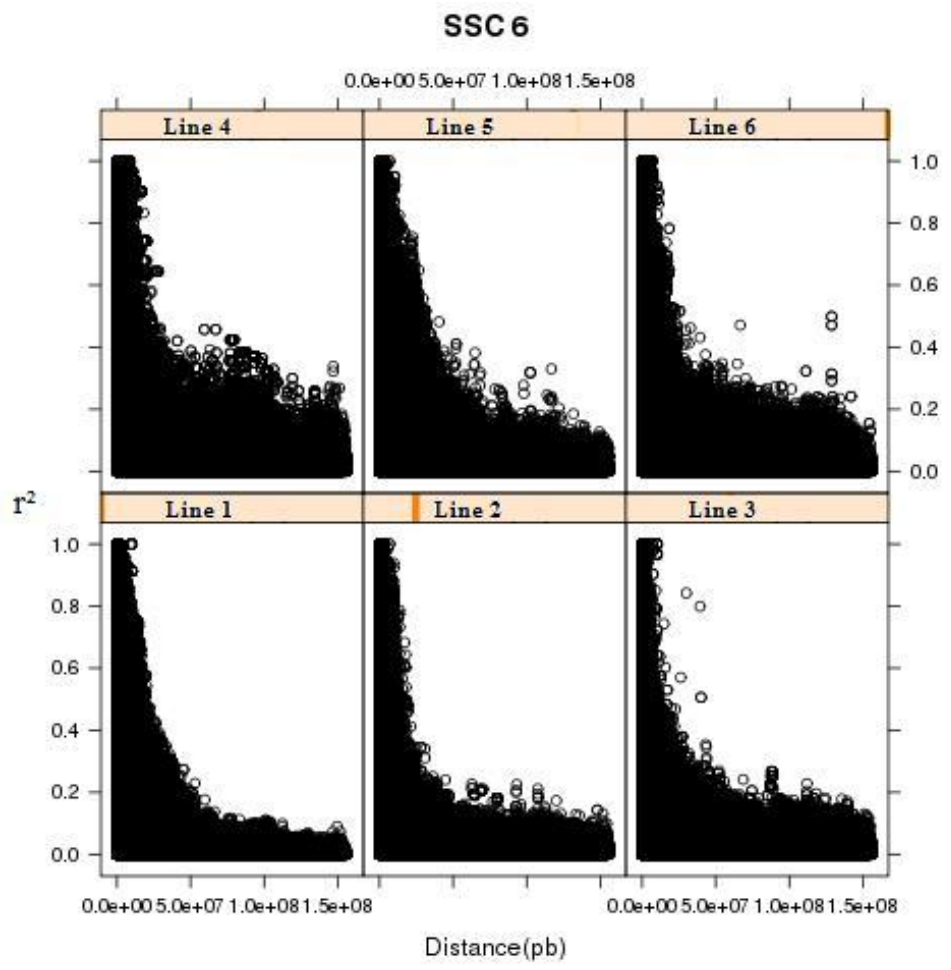

Figure 6

Linkage Disequilibrium between SNP pairs in relation to physical distance between loci in pig chromosome 6 for six commercial lines. 
$\operatorname{SSC} 7$

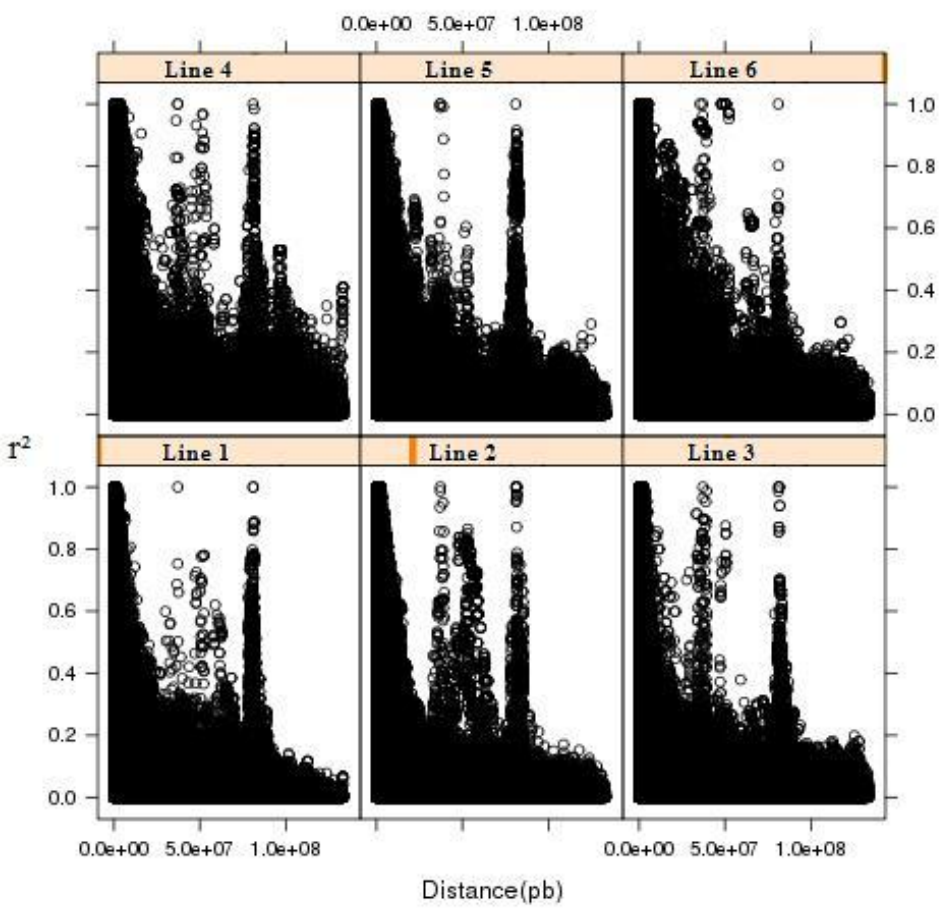

Figure 7

Linkage Disequilibrium between SNP pairs in relation to physical distance between loci in pig chromosome 7 for six commercial lines.

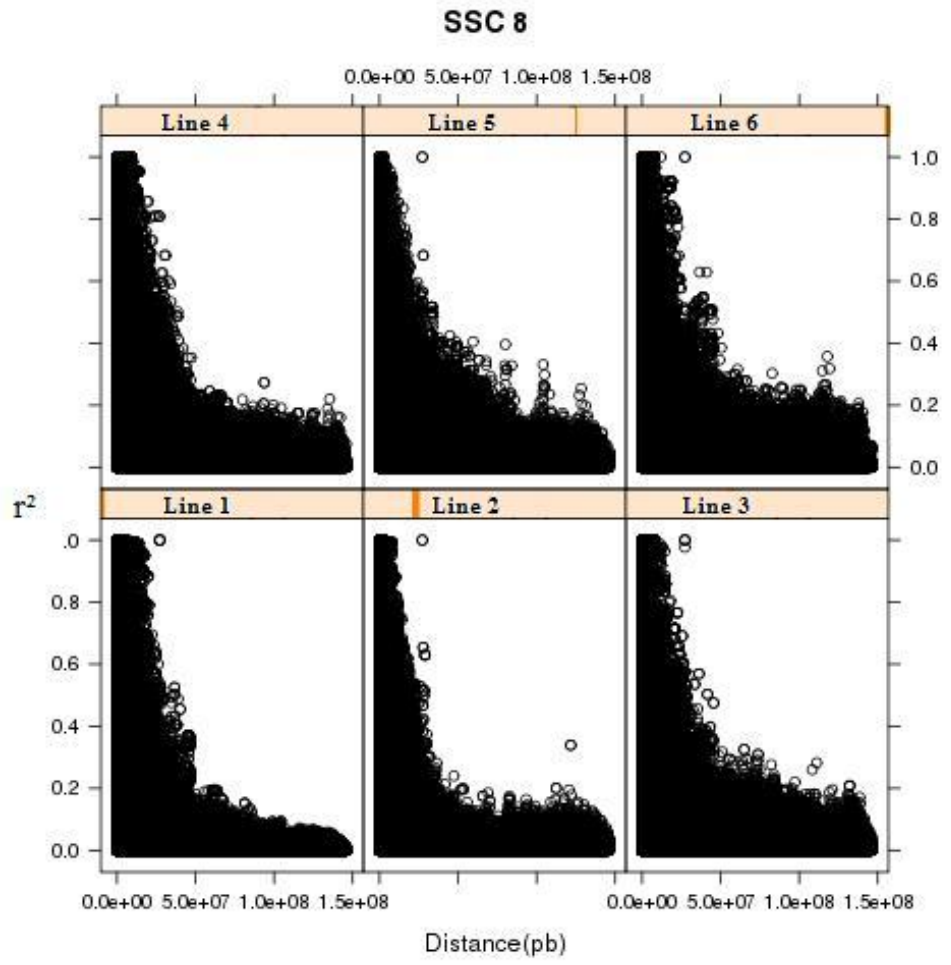

Figure 8

Linkage Disequilibrium between SNP pairs in relation to physical distance between loci in pig chromosome 8 for six commercial lines. 
$\operatorname{SSC} 9$

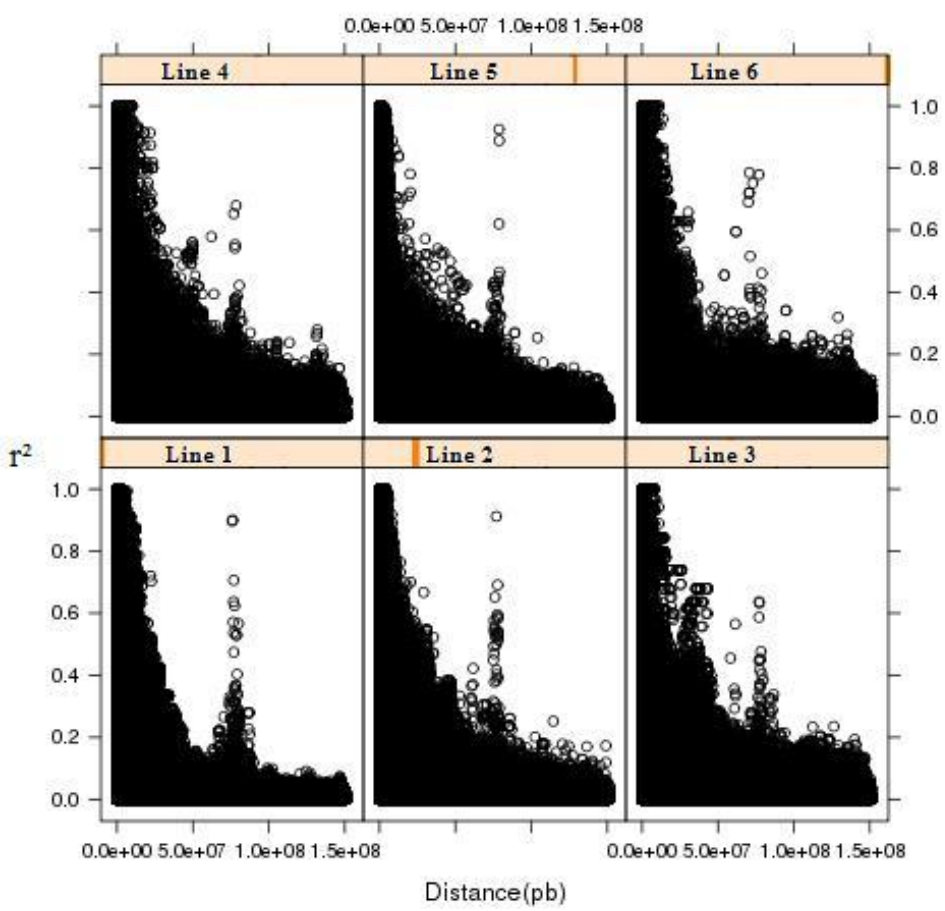

Figure 9

Linkage Disequilibrium between SNP pairs in relation to physical distance between loci in pig chromosome 9 for six commercial lines.

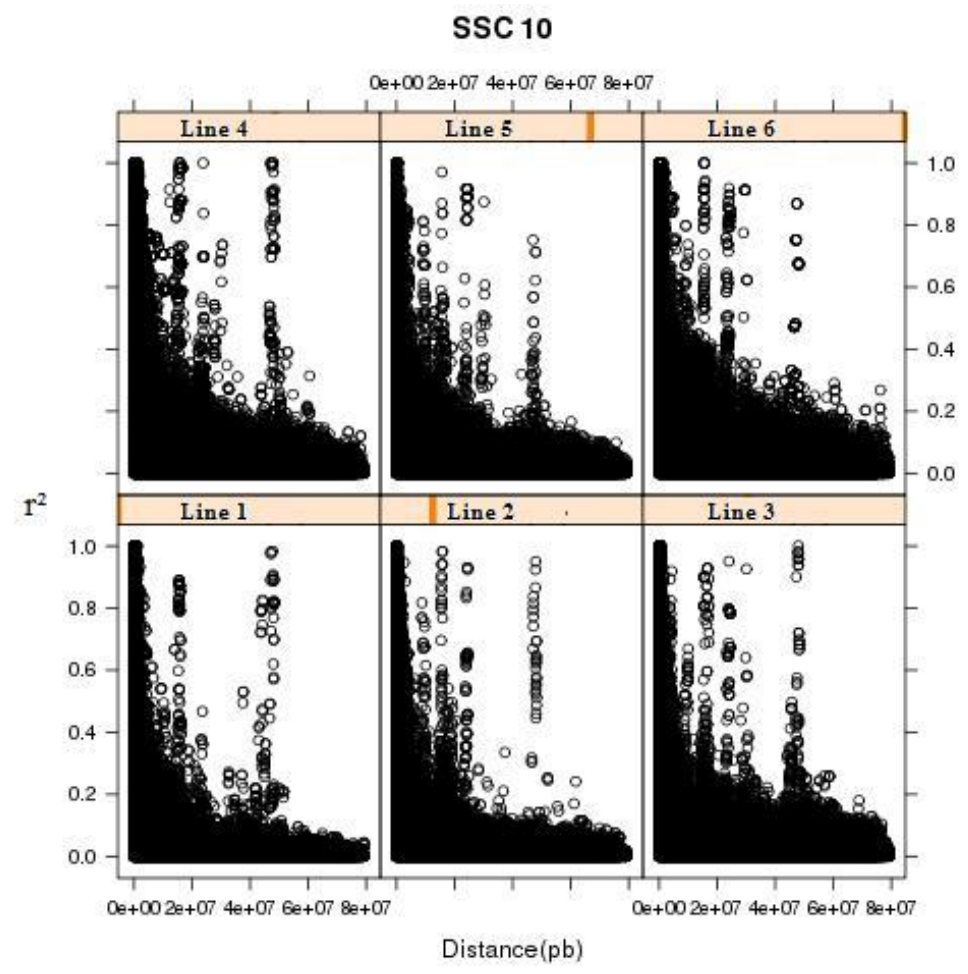

Figure 10

Linkage Disequilibrium between SNP pairs in relation to physical distance between loci in pig chromosome 10 for six commercial lines. 


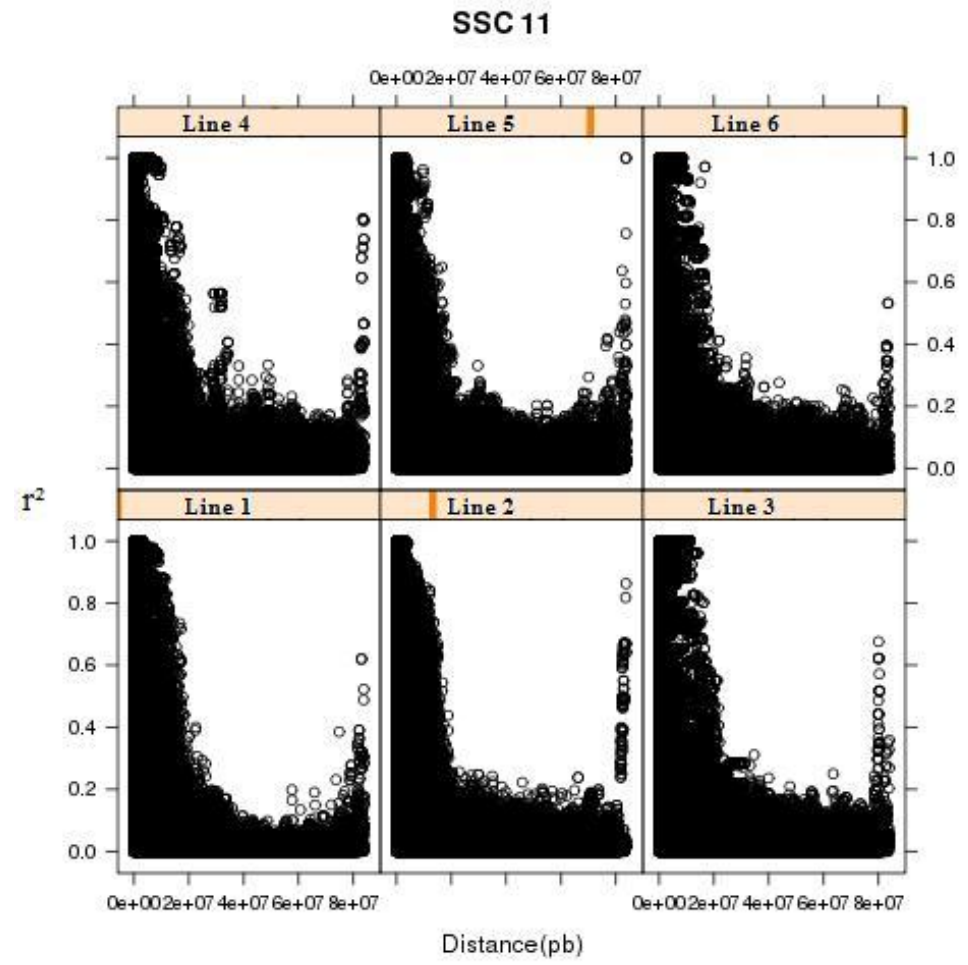

Figure 11

Linkage Disequilibrium between SNP pairs in relation to physical distance between loci in pig chromosome 11 for six commercial lines.

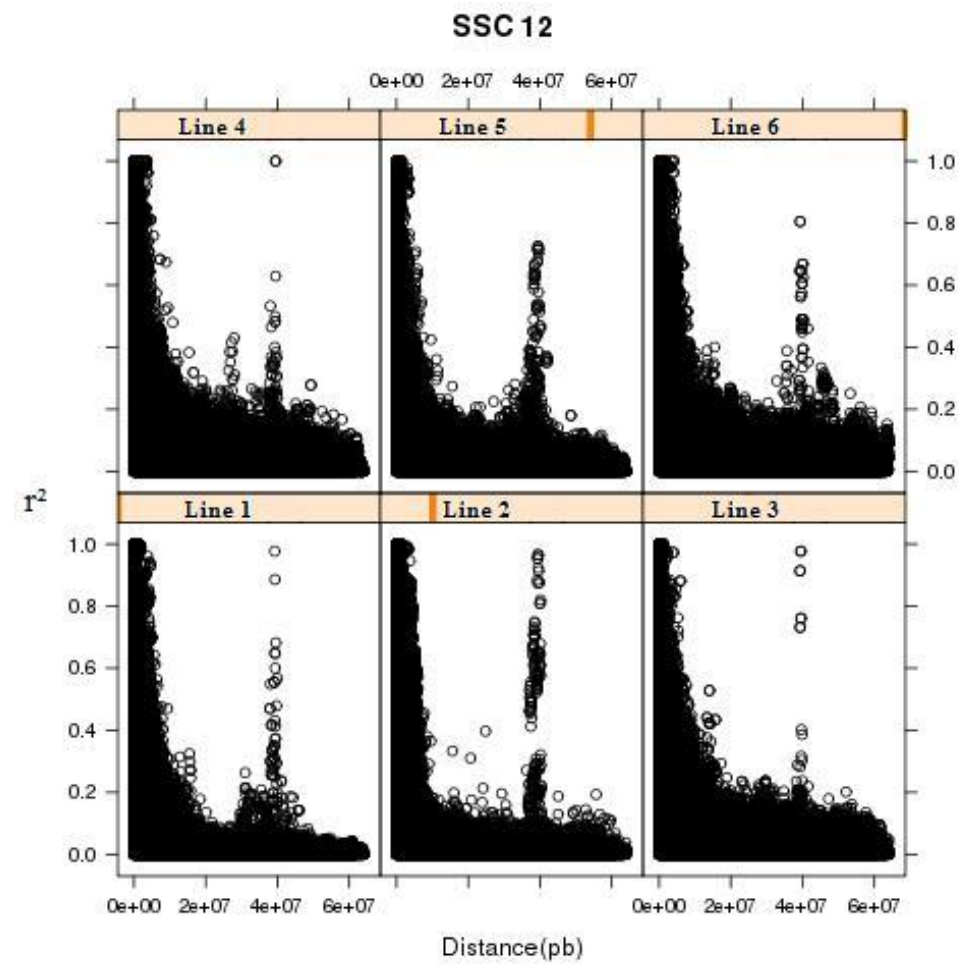

Figure 12

Linkage Disequilibrium between SNP pairs in relation to physical distance between loci in pig chromosome 12 for six commercial lines. 


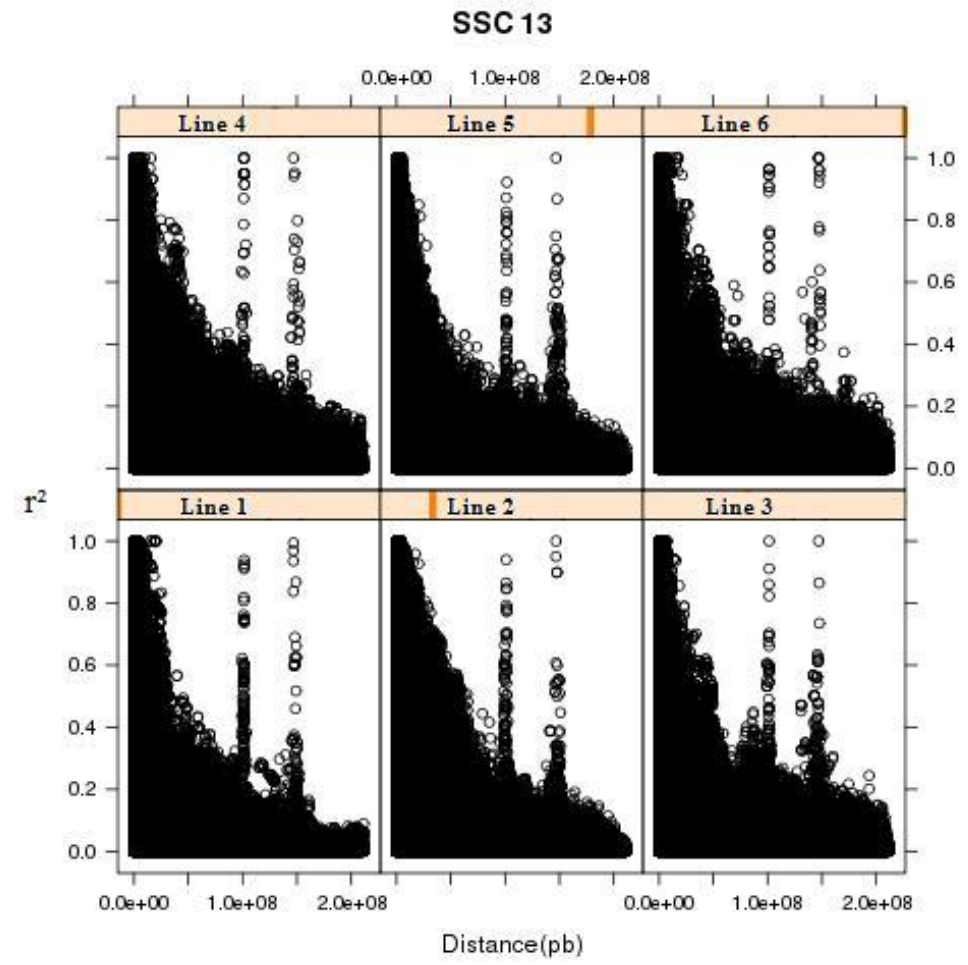

Figure 13

Linkage Disequilibrium between SNP pairs in relation to physical distance between loci in pig chromosome 13 for six commercial lines.

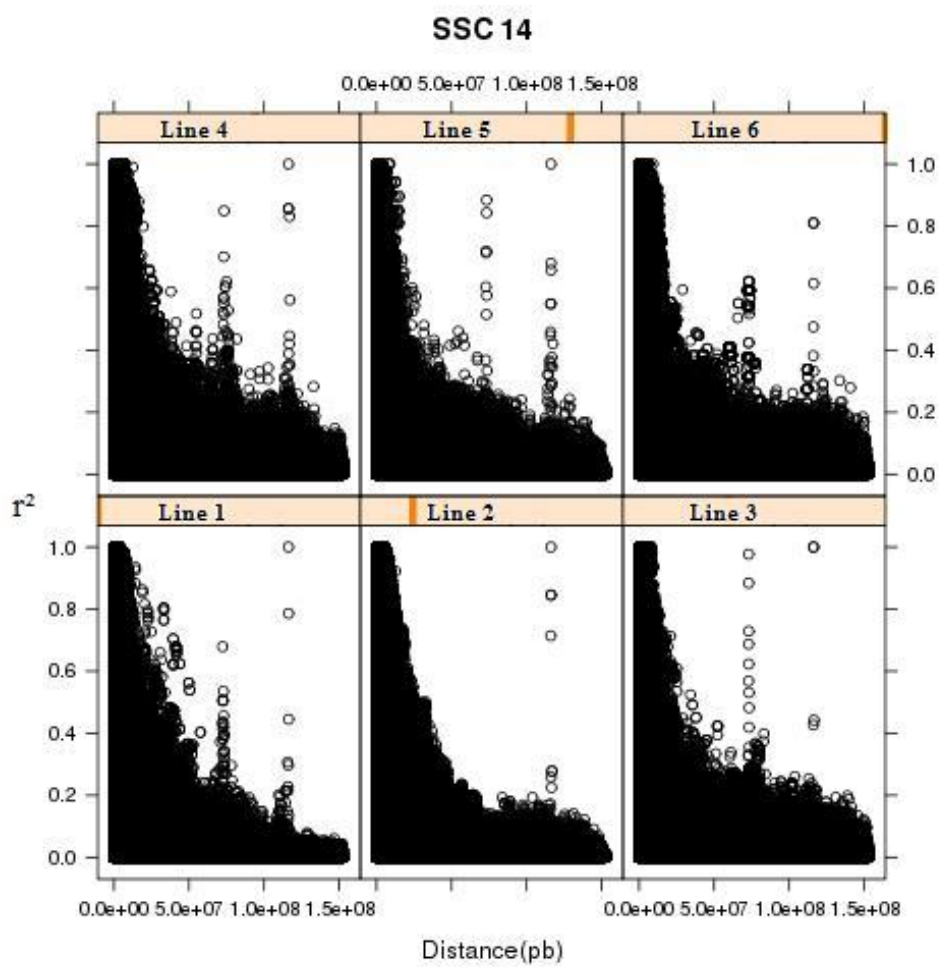

Figure 14

Linkage Disequilibrium between SNP pairs in relation to physical distance between loci in pig chromosome 14 for six commercial lines. 


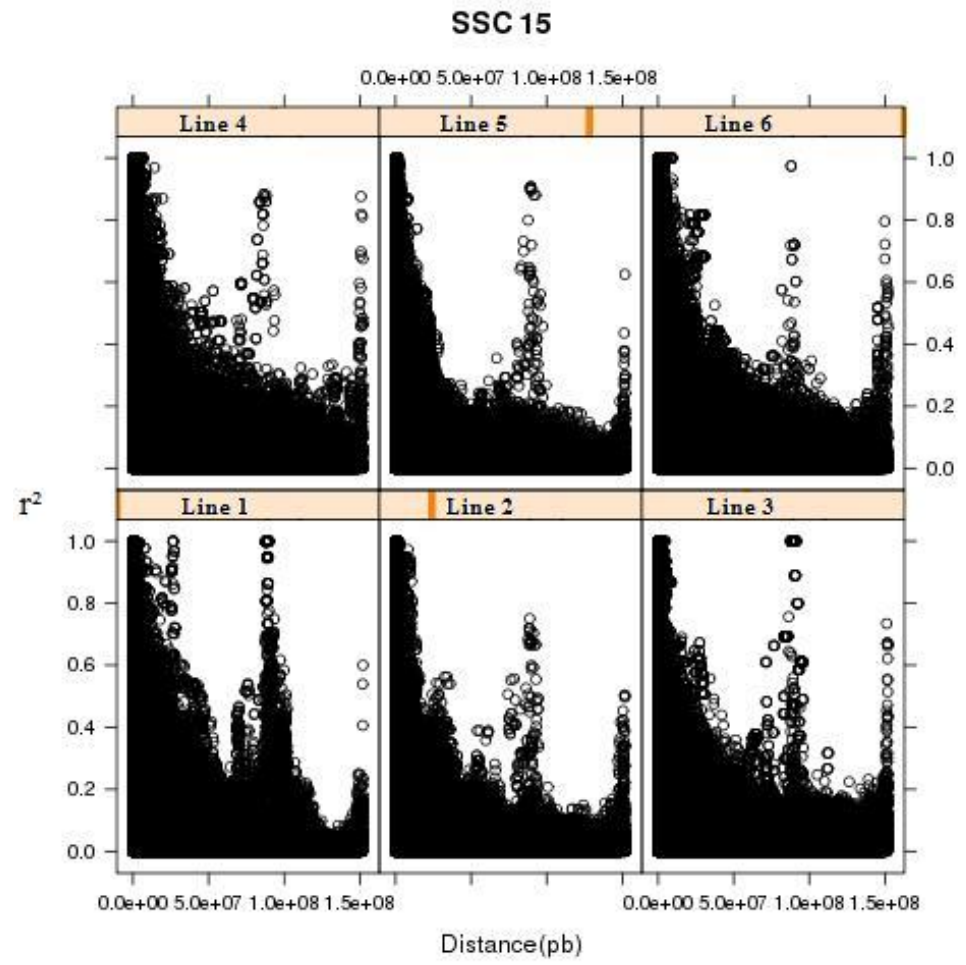

Figure 15

Linkage Disequilibrium between SNP pairs in relation to physical distance between loci in pig chromosome 15 for six commercial lines.

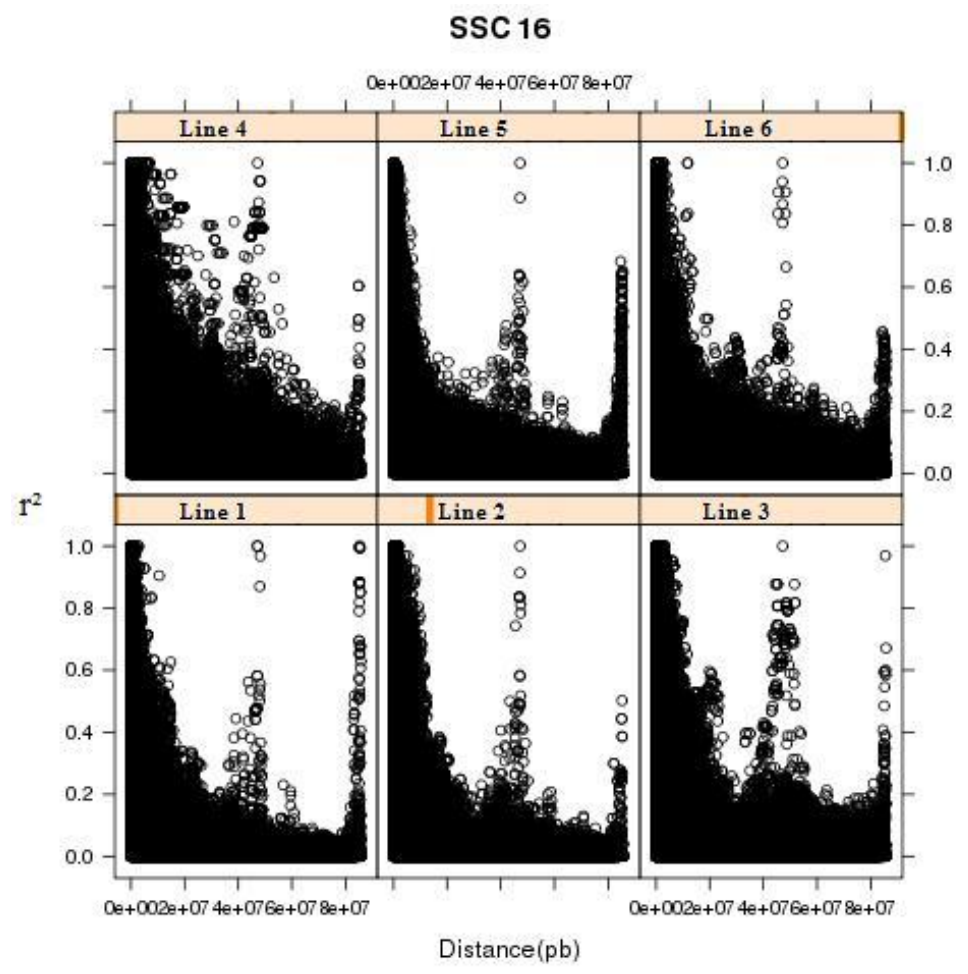

Figure 16

Linkage Disequilibrium between SNP pairs in relation to physical distance between loci in pig chromosome 16 for six commercial lines. 


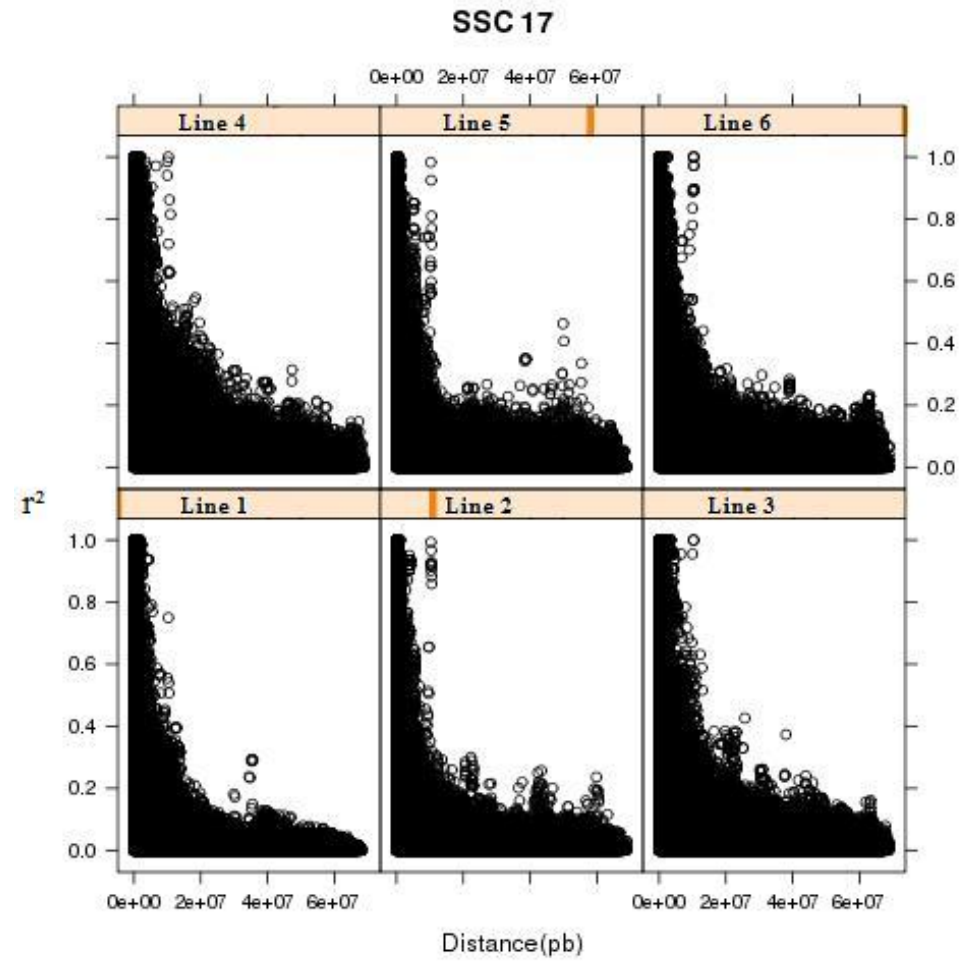

Figure 17

Linkage Disequilibrium between SNP pairs in relation to physical distance between loci in pig chromosome 17 for six commercial lines.

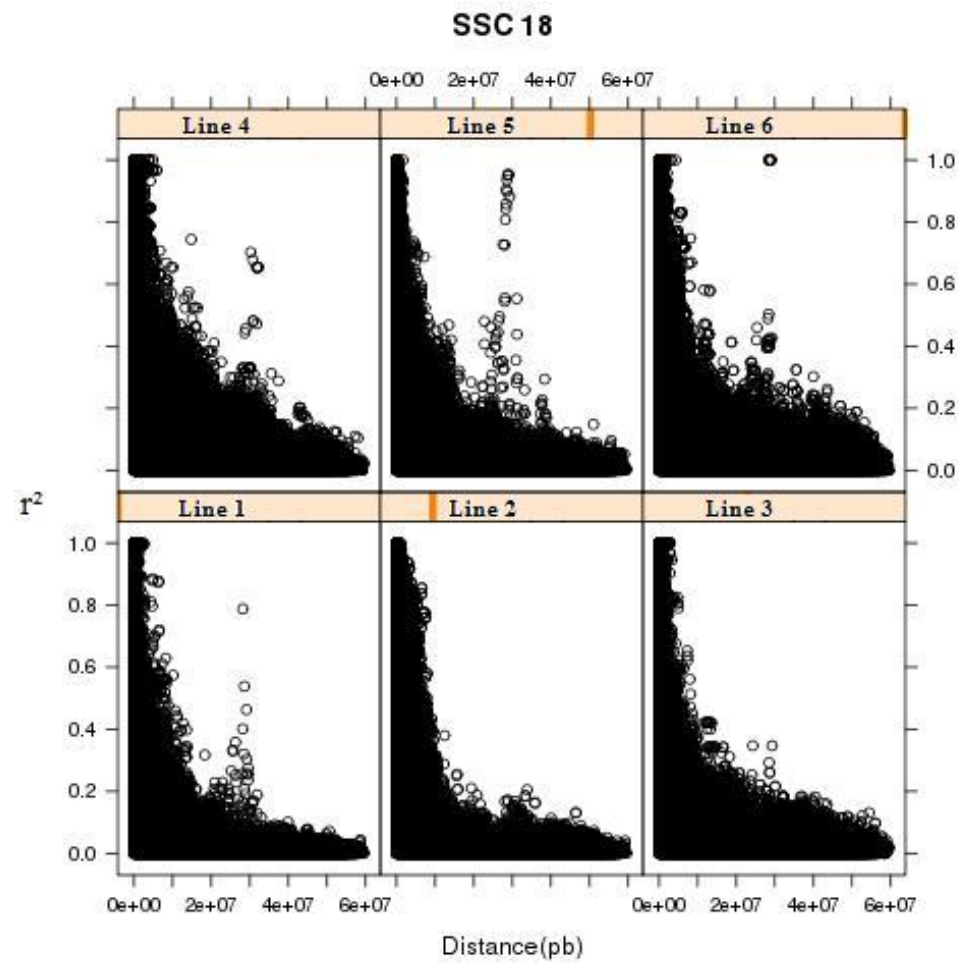

Figure 18

Linkage Disequilibrium between SNP pairs in relation to physical distance between loci in pig chromosome 18 for six commercial lines. 
Table 2. Number of blocks, total number of SNPs in the blocks, average number SNP / block, standard deviation number of SNP / block, average block size $(\mathrm{Kb})$, standard deviation block size $(\mathrm{Kb})$, maximum block size $(\mathrm{Kb})$ and minimum block size $(\mathrm{Kb})$.

\begin{tabular}{|c|c|c|c|c|c|c|c|c|}
\hline \multicolumn{9}{|c|}{ SSC1 } \\
\hline Line & $\begin{array}{l}\text { Number } \\
\text { of } \\
\text { blocks }\end{array}$ & $\begin{array}{l}\text { Total number of } \\
\text { SNPs in the } \\
\text { blocks }\end{array}$ & $\begin{array}{c}\text { Average } \\
\text { number of } \\
\text { SNP/ block }\end{array}$ & $\begin{array}{c}\text { SD number } \\
\text { of SNP/ } \\
\text { block }\end{array}$ & $\begin{array}{l}\text { Average block } \\
\text { size }(\mathrm{Kb})\end{array}$ & $\begin{array}{l}\text { SD block } \\
\text { size }(\mathrm{Kb})\end{array}$ & $\begin{array}{l}\text { Maximum } \\
\text { Block size } \\
\quad(\mathrm{Kb})\end{array}$ & $\begin{array}{c}\text { Minimum } \\
\text { block size }(\mathrm{Kb})\end{array}$ \\
\hline 1 & 415 & 3,018 & 7.272 & 7.513 & 407.711 & 649.653 & 0.028 & 5658.450 \\
\hline 2 & 410 & 3,049 & 7.437 & 6.539 & 398.807 & 533.019 & 0.028 & 3810.670 \\
\hline 3 & 382 & 2,939 & 7.694 & 8.150 & 454.669 & 892.514 & 0.358 & 9889.490 \\
\hline 4 & 391 & 2,850 & 7.289 & 6.611 & 393.074 & 531.058 & 0.025 & 3973.860 \\
\hline 5 & 420 & 2,956 & 7.038 & 6.447 & 360.708 & 520.886 & 0.025 & 4484.410 \\
\hline 6 & 416 & 3,187 & 7.661 & 7.116 & 410.359 & 589.244 & 0.025 & 5303.950 \\
\hline \multicolumn{9}{|c|}{ SSC2 } \\
\hline Line & $\begin{array}{l}\text { Number } \\
\text { of } \\
\text { blocks }\end{array}$ & $\begin{array}{l}\text { Total number of } \\
\text { SNPs in the } \\
\text { blocks }\end{array}$ & $\begin{array}{c}\text { Average } \\
\text { number of } \\
\text { SNP/ block }\end{array}$ & $\begin{array}{c}\text { SD number } \\
\text { of SNP/ } \\
\text { block }\end{array}$ & $\begin{array}{l}\text { Average block } \\
\text { size }(\mathrm{Kb})\end{array}$ & $\begin{array}{l}\text { SD block } \\
\text { size }(\mathrm{Kb})\end{array}$ & $\begin{array}{c}\text { Maximum } \\
\text { Block size } \\
(\mathrm{Kb})\end{array}$ & $\begin{array}{c}\text { Minimum } \\
\text { block size }(\mathrm{Kb})\end{array}$ \\
\hline 1 & 273 & 1,484 & 5.436 & 4.310 & 257.003 & 404.701 & 0.120 & 3176.680 \\
\hline 2 & 243 & 1,398 & 5.753 & 5.182 & 309.329 & 637.668 & 0.153 & 6314.630 \\
\hline 3 & 271 & 1,328 & 4.900 & 3.797 & 236.270 & 433.180 & 0.153 & 4878.920 \\
\hline 4 & 221 & 1,451 & 6.566 & 7.264 & 384.586 & 707.005 & 0.153 & 4790.340 \\
\hline 5 & 293 & 1,353 & 4.618 & 3.755 & 201.700 & 398.609 & 0.153 & 4069.410 \\
\hline 6 & 248 & 1,402 & 5.653 & 4.978 & 254.514 & 409.605 & 0.153 & 3352.020 \\
\hline
\end{tabular}


Cont. Table 2. Number of blocks, total number of SNPs in the blocks, average number SNP / block, standard deviation number of SNP / block, average block size $(\mathrm{Kb})$, standard deviation block size $(\mathrm{Kb})$, maximum block size $(\mathrm{Kb})$ and minimum block size $(\mathrm{Kb})$.

\begin{tabular}{|c|c|c|c|c|c|c|c|c|}
\hline \multicolumn{9}{|c|}{ SSC3 } \\
\hline Line & $\begin{array}{c}\text { Number } \\
\text { of } \\
\text { blocks } \\
\end{array}$ & $\begin{array}{c}\text { Total number of } \\
\text { SNPs in the } \\
\text { blocks }\end{array}$ & $\begin{array}{c}\text { Average } \\
\text { number of } \\
\text { SNP/ block } \\
\end{array}$ & $\begin{array}{c}\text { SD number } \\
\text { of SNP/ } \\
\text { block } \\
\end{array}$ & $\begin{array}{l}\text { Average block } \\
\text { size }(\mathrm{Kb})\end{array}$ & $\begin{array}{l}\text { SD block } \\
\text { size }(\mathrm{Kb})\end{array}$ & $\begin{array}{c}\text { Maximum } \\
\text { Block size } \\
(\mathrm{Kb}) \\
\end{array}$ & $\begin{array}{c}\text { Minimum } \\
\text { block size }(\mathrm{Kb})\end{array}$ \\
\hline 1 & 224 & 1,024 & 4.571 & 3.555 & 222.899 & 348.721 & 0.165 & 2309.850 \\
\hline 2 & 199 & 1,066 & 5.357 & 4.303 & 280.085 & 436.220 & 0.078 & 3633.280 \\
\hline 3 & 216 & 1,084 & 5.019 & 3.967 & 257.602 & 406.892 & 0.078 & 3673.590 \\
\hline 4 & 227 & 1,070 & 4.714 & 3.673 & 212.348 & 303.108 & 0.761 & 1741.430 \\
\hline 5 & 243 & 987 & 4.062 & 2.840 & 152.532 & 227.254 & 0.165 & 1416.070 \\
\hline 6 & 206 & 992 & 4.816 & 3.986 & 216.364 & 330.359 & 0.078 & 1891.680 \\
\hline \multicolumn{9}{|c|}{ SSC4 } \\
\hline Line & $\begin{array}{c}\text { Number } \\
\text { of } \\
\text { blocks }\end{array}$ & $\begin{array}{l}\text { Total number of } \\
\text { SNPs in the } \\
\text { blocks }\end{array}$ & $\begin{array}{c}\text { Average } \\
\text { number of } \\
\text { SNP/ block }\end{array}$ & $\begin{array}{l}\text { SD number } \\
\text { of SNP/ } \\
\text { block }\end{array}$ & $\begin{array}{l}\text { Average block } \\
\text { size }(\mathrm{Kb})\end{array}$ & $\begin{array}{l}\text { SD block } \\
\text { size }(\mathrm{Kb})\end{array}$ & $\begin{array}{c}\text { Maximum } \\
\text { Block size } \\
(\mathrm{Kb})\end{array}$ & $\begin{array}{c}\text { Minimum } \\
\text { block size }(\mathrm{Kb})\end{array}$ \\
\hline 1 & 310 & 1,554 & 5.013 & 4.991 & 196.349 & 435.027 & 0.180 & 6656.220 \\
\hline 2 & 236 & 1,297 & 5.496 & 5.630 & 235.413 & 474.297 & 0.651 & 5255.580 \\
\hline 3 & 240 & 1,415 & 5.896 & 6.720 & 248.801 & 457.508 & 0.651 & 5431.330 \\
\hline 4 & 243 & 1,463 & 6.021 & 6.156 & 274.070 & 510.712 & 1.310 & 6211.920 \\
\hline 5 & 247 & 1,338 & 5.417 & 5.850 & 208.934 & 443.406 & 0.651 & 5341.820 \\
\hline 6 & 216 & 1,306 & 6.046 & 5.901 & 276.028 & 552.217 & 2.217 & 5659.440 \\
\hline
\end{tabular}


Cont. Table 2. Number of blocks, total number of SNPs in the blocks, average number SNP / block, standard deviation number of SNP / block, average block size $(\mathrm{Kb})$, standard deviation block size $(\mathrm{Kb})$, maximum block size $(\mathrm{Kb})$ and minimum block size $(\mathrm{Kb})$.

\begin{tabular}{|c|c|c|c|c|c|c|c|c|}
\hline \multicolumn{9}{|c|}{ SSC5 } \\
\hline Line & $\begin{array}{c}\text { Number } \\
\text { of } \\
\text { blocks } \\
\end{array}$ & $\begin{array}{c}\text { Total number of } \\
\text { SNPs in the } \\
\text { blocks }\end{array}$ & $\begin{array}{c}\text { Average } \\
\text { number of } \\
\text { SNP/ block } \\
\end{array}$ & $\begin{array}{c}\begin{array}{c}\text { SD number } \\
\text { of SNP/ } \\
\text { block }\end{array} \\
\end{array}$ & $\begin{array}{l}\text { Average block } \\
\text { size }(\mathrm{Kb})\end{array}$ & $\begin{array}{l}\text { SD block } \\
\text { size }(\mathrm{Kb})\end{array}$ & $\begin{array}{c}\text { Maximum } \\
\text { Block size } \\
(\mathrm{Kb}) \\
\end{array}$ & $\begin{array}{c}\text { Minimum } \\
\text { block size }(\mathrm{Kb})\end{array}$ \\
\hline 1 & 166 & 851 & 5.127 & 4.036 & 240.734 & 386.136 & 3.246 & 2835.580 \\
\hline 2 & 171 & 904 & 5.287 & 4.728 & 256.248 & 467.214 & 1.076 & 4447.230 \\
\hline 3 & 159 & 763 & 4.799 & 3.598 & 226.575 & 294.402 & 0.017 & 1745.980 \\
\hline 4 & 162 & 918 & 5.667 & 4.772 & 332.321 & 498.366 & 0.017 & 4028.970 \\
\hline 5 & 177 & 780 & 4.407 & 3.121 & 198.564 & 313.192 & 0.186 & 1945.660 \\
\hline 6 & 152 & 820 & 5.395 & 4.288 & 263.464 & 370.645 & 0.017 & 1825.990 \\
\hline \multicolumn{9}{|c|}{ SSC6 } \\
\hline Line & $\begin{array}{c}\text { Number } \\
\text { of } \\
\text { blocks } \\
\end{array}$ & $\begin{array}{c}\text { Total number of } \\
\text { SNPs in the } \\
\text { blocks }\end{array}$ & $\begin{array}{c}\text { Average } \\
\text { number of } \\
\text { SNP/ block } \\
\end{array}$ & $\begin{array}{c}\begin{array}{c}\text { SD number } \\
\text { of SNP/ } \\
\text { block }\end{array} \\
\end{array}$ & $\begin{array}{l}\text { Average block } \\
\text { size }(\mathrm{Kb})\end{array}$ & $\begin{array}{l}\text { SD block } \\
\text { size }(\mathrm{Kb})\end{array}$ & $\begin{array}{c}\text { Maximum } \\
\text { Block size } \\
(\mathrm{Kb}) \\
\end{array}$ & $\begin{array}{c}\text { Minimum } \\
\text { block size }(\mathrm{Kb})\end{array}$ \\
\hline 1 & 256 & 1,423 & 5.559 & 5.803 & 303.521 & 657.056 & 0.161 & 6075.710 \\
\hline 2 & 238 & 1,251 & 5.256 & 4.854 & 272.235 & 543.398 & 0.164 & 5482.680 \\
\hline 3 & 246 & 1,367 & 5.557 & 5.459 & 299.627 & 579.075 & 0.061 & 5647.650 \\
\hline 4 & 221 & 1,299 & 5.878 & 5.242 & 335.502 & 569.661 & 0.164 & 5098.040 \\
\hline 5 & 228 & 1,198 & 5.254 & 4.899 & 265.950 & 497.240 & 0.061 & 3601.010 \\
\hline 6 & 212 & 1,252 & 5.906 & 6.481 & 304.916 & 704.741 & 0.061 & 8178.190 \\
\hline
\end{tabular}


Cont. Table 2. Number of blocks, total number of SNPs in the blocks, average number SNP / block, standard deviation number of SNP / block, average block size $(\mathrm{Kb})$, standard deviation block size $(\mathrm{Kb})$, maximum block size $(\mathrm{Kb})$ and minimum block size $(\mathrm{Kb})$.

\begin{tabular}{|c|c|c|c|c|c|c|c|c|}
\hline \multicolumn{9}{|c|}{ SSC7 } \\
\hline Line & $\begin{array}{c}\text { Number } \\
\text { of } \\
\text { blocks } \\
\end{array}$ & $\begin{array}{l}\text { Total number of } \\
\text { SNPs in the } \\
\text { blocks }\end{array}$ & $\begin{array}{c}\text { Average } \\
\text { number of } \\
\text { SNP/ block } \\
\end{array}$ & $\begin{array}{c}\text { SD number } \\
\text { of SNP/ } \\
\text { block } \\
\end{array}$ & $\begin{array}{l}\text { Average block } \\
\text { size }(\mathrm{Kb})\end{array}$ & $\begin{array}{l}\text { SD block } \\
\text { size }(\mathrm{Kb})\end{array}$ & $\begin{array}{c}\text { Maximum } \\
\text { Block size } \\
(\mathrm{Kb})\end{array}$ & $\begin{array}{c}\text { Minimum } \\
\text { block size }(\mathrm{Kb})\end{array}$ \\
\hline 1 & 206 & 1,196 & 5.806 & 4.857 & 266.944 & 380.293 & 0.189 & 2594.350 \\
\hline 2 & 214 & 1,303 & 6.089 & 6.417 & 269.331 & 446.712 & 2.003 & 3889.550 \\
\hline 3 & 193 & 1,087 & 5.632 & 5.740 & 225.973 & 371.153 & 2.798 & 2536.370 \\
\hline 4 & 204 & 1,167 & 5.721 & 5.385 & 276.376 & 442.455 & 2.003 & 2860.270 \\
\hline 5 & 216 & 1,227 & 5.681 & 5.530 & 241.824 & 385.482 & 2.003 & 3676.670 \\
\hline 6 & 196 & 1,226 & 6.255 & 6.774 & 270.695 & 451.560 & 2.003 & 4286.290 \\
\hline \multicolumn{9}{|c|}{ SSC8 } \\
\hline Line & $\begin{array}{c}\text { Number } \\
\text { of } \\
\text { blocks }\end{array}$ & $\begin{array}{c}\text { Total number of } \\
\text { SNPs in the } \\
\text { blocks }\end{array}$ & $\begin{array}{c}\text { Average } \\
\text { number of } \\
\text { SNP/ block }\end{array}$ & $\begin{array}{c}\text { SD number } \\
\text { of SNP/ } \\
\text { block } \\
\end{array}$ & $\begin{array}{l}\text { Average block } \\
\text { size }(\mathrm{Kb})\end{array}$ & $\begin{array}{l}\text { SD block } \\
\text { size }(\mathrm{Kb})\end{array}$ & $\begin{array}{c}\text { Maximum } \\
\text { Block size } \\
(\mathrm{Kb}) \\
\end{array}$ & $\begin{array}{c}\text { Minimum } \\
\text { block size }(\mathrm{Kb})\end{array}$ \\
\hline 1 & 211 & 1,163 & 5.512 & 5.891 & 342.879 & 633.601 & 0.317 & 4885.830 \\
\hline 2 & 182 & 1,060 & 5.824 & 6.035 & 371.049 & 903.434 & 0.250 & 9654.750 \\
\hline 3 & 217 & 1,009 & 4.650 & 3.402 & 249.708 & 444.328 & 0.301 & 3255.010 \\
\hline 4 & 158 & 1,024 & 6.481 & 7.104 & 490.930 & 1439.820 & 0.314 & 16589.580 \\
\hline 5 & 168 & 800 & 4.762 & 4.397 & 292.754 & 454.570 & 0.250 & 2463.200 \\
\hline 6 & 189 & 1,017 & 5.381 & 5.068 & 319.040 & 866.073 & 0.158 & 10845.340 \\
\hline
\end{tabular}


Cont. Table 2. Number of blocks, total number of SNPs in the blocks, average number SNP / block, standard deviation number of SNP / block, average block size $(\mathrm{Kb})$, standard deviation block size $(\mathrm{Kb})$, maximum block size $(\mathrm{Kb})$ and minimum block size $(\mathrm{Kb})$.

\begin{tabular}{|c|c|c|c|c|c|c|c|c|}
\hline \multicolumn{9}{|c|}{ SSC9 } \\
\hline Line & $\begin{array}{c}\text { Number } \\
\text { of } \\
\text { blocks } \\
\end{array}$ & $\begin{array}{c}\text { Total number of } \\
\text { SNPs in the } \\
\text { blocks }\end{array}$ & $\begin{array}{c}\text { Average } \\
\text { number of } \\
\text { SNP/ block } \\
\end{array}$ & $\begin{array}{c}\text { SD number } \\
\text { of SNP/ } \\
\text { block } \\
\end{array}$ & $\begin{array}{l}\text { Average block } \\
\text { size }(\mathrm{Kb})\end{array}$ & $\begin{array}{l}\text { SD block } \\
\text { size }(\mathrm{Kb})\end{array}$ & $\begin{array}{c}\text { Maximum } \\
\text { Block size } \\
(\mathrm{Kb}) \\
\end{array}$ & $\begin{array}{c}\text { Minimum } \\
\text { block size }(\mathrm{Kb})\end{array}$ \\
\hline 1 & 277 & 1,302 & 4.700 & 4.016 & 239.480 & 413.730 & 0.069 & 3480.660 \\
\hline 2 & 251 & 1,352 & 5.386 & 4.499 & 257.768 & 370.103 & 0.360 & 2272.700 \\
\hline 3 & 265 & 1,266 & 4.777 & 4.361 & 207.247 & 333.159 & 0.030 & 2552.340 \\
\hline 4 & 246 & 1,386 & 5.634 & 5.070 & 282.608 & 417.853 & 0.069 & 2378.920 \\
\hline 5 & 265 & 1,164 & 4.392 & 4.097 & 178.290 & 308.094 & 0.153 & 2016.850 \\
\hline 6 & 225 & 1,295 & 5.756 & 4.946 & 310.849 & 449.450 & 0.153 & 2376.340 \\
\hline \multicolumn{9}{|c|}{ SSC10 } \\
\hline Line & $\begin{array}{c}\text { Number } \\
\text { of } \\
\text { blocks } \\
\end{array}$ & $\begin{array}{c}\text { Total number of } \\
\text { SNPs in the } \\
\text { blocks }\end{array}$ & $\begin{array}{c}\text { Average } \\
\text { number of } \\
\text { SNP/ block } \\
\end{array}$ & $\begin{array}{c}\text { Sd number } \\
\text { of SNP/ } \\
\text { block } \\
\end{array}$ & $\begin{array}{l}\text { Average block } \\
\text { size }(\mathrm{Kb})\end{array}$ & $\begin{array}{l}\text { Sd block size } \\
(\mathrm{Kb})\end{array}$ & $\begin{array}{c}\text { Maximum } \\
\text { Block size } \\
(\mathrm{Kb}) \\
\end{array}$ & $\begin{array}{c}\text { Minimum } \\
\text { block size }(\mathrm{Kb})\end{array}$ \\
\hline 1 & 126 & 500 & 3.968 & 3.392 & 155.350 & 292.867 & 0.035 & 1988.280 \\
\hline 2 & 113 & 452 & 4.000 & 2.712 & 147.799 & 229.374 & 2.083 & 1424.600 \\
\hline 3 & 109 & 487 & 4.468 & 2.911 & 183.127 & 259.740 & 0.077 & 1375.860 \\
\hline 4 & 113 & 610 & 5.398 & 4.918 & 280.150 & 469.651 & 0.077 & 3567.660 \\
\hline 5 & 115 & 460 & 4.000 & 2.421 & 134.943 & 211.903 & 1.159 & 1491.330 \\
\hline 6 & 115 & 525 & 4.565 & 4.044 & 189.444 & 305.406 & 0.964 & 1913.480 \\
\hline
\end{tabular}


Cont. Table 2. Number of blocks, total number of SNPs in the blocks, average number SNP / block, standard deviation number of SNP / block, average block size $(\mathrm{Kb})$, standard deviation block size $(\mathrm{Kb})$, maximum block size $(\mathrm{Kb})$ and minimum block size $(\mathrm{Kb})$.

\begin{tabular}{|c|c|c|c|c|c|c|c|c|}
\hline \multicolumn{9}{|c|}{ SSC11 } \\
\hline Line & $\begin{array}{c}\text { Number } \\
\text { of } \\
\text { blocks }\end{array}$ & $\begin{array}{c}\text { Total number of } \\
\text { SNPs in the } \\
\text { blocks }\end{array}$ & $\begin{array}{c}\text { Average } \\
\text { number of } \\
\text { SNP/ block } \\
\end{array}$ & $\begin{array}{c}\text { SD number } \\
\text { of SNP/ } \\
\text { block } \\
\end{array}$ & $\begin{array}{l}\text { Average block } \\
\text { size }(\mathrm{Kb})\end{array}$ & $\begin{array}{l}\text { SD block } \\
\text { size }(\mathrm{Kb})\end{array}$ & $\begin{array}{c}\text { Maximum } \\
\text { Block size } \\
(\mathrm{Kb}) \\
\end{array}$ & $\begin{array}{c}\text { Minimum } \\
\text { block size }(\mathrm{Kb})\end{array}$ \\
\hline 1 & 153 & 704 & 4.601 & 3.767 & 192.548 & 299.038 & 0.170 & 2063.090 \\
\hline 2 & 130 & 636 & 4.892 & 5.257 & 232.806 & 529.103 & 0.170 & 4411.690 \\
\hline 3 & 131 & 672 & 5.130 & 7.344 & 250.897 & 633.445 & 0.170 & 6382.570 \\
\hline 4 & 133 & 677 & 5.090 & 7.817 & 254.693 & 664.822 & 1.666 & 6691.500 \\
\hline 5 & 148 & 643 & 4.345 & 4.191 & 177.213 & 387.809 & 0.170 & 3189.320 \\
\hline 6 & 114 & 659 & 5.781 & 8.315 & 275.943 & 688.055 & 0.170 & 6745.410 \\
\hline \multicolumn{9}{|c|}{ SSC12 } \\
\hline Line & $\begin{array}{c}\text { Number } \\
\text { of } \\
\text { blocks }\end{array}$ & $\begin{array}{c}\text { Total number of } \\
\text { SNPs in the } \\
\text { blocks }\end{array}$ & $\begin{array}{c}\text { Average } \\
\text { number of } \\
\text { SNP/ block }\end{array}$ & $\begin{array}{c}\text { Sd number } \\
\text { of SNP/ } \\
\text { block }\end{array}$ & $\begin{array}{l}\text { Average block } \\
\text { size }(\mathrm{Kb})\end{array}$ & $\begin{array}{l}\text { Sd block size } \\
(\mathrm{Kb})\end{array}$ & $\begin{array}{c}\text { Maximum } \\
\text { Block size } \\
(\mathrm{Kb})\end{array}$ & $\begin{array}{c}\text { Minimum } \\
\text { block size }(\mathrm{Kb})\end{array}$ \\
\hline 1 & 148 & 567 & 3.831 & 3.157 & 121.874 & 229.591 & 0.029 & 1968.790 \\
\hline 2 & 130 & 532 & 4.092 & 3.214 & 147.389 & 230.071 & 0.029 & 1110.500 \\
\hline 3 & 145 & 534 & 3.683 & 2.715 & 109.896 & 187.949 & 0.029 & 1110.010 \\
\hline 4 & 137 & 594 & 4.336 & 3.088 & 153.116 & 240.316 & 0.029 & 1574.380 \\
\hline 5 & 145 & 567 & 3.910 & 3.356 & 123.964 & 227.085 & 0.029 & 1574.380 \\
\hline 6 & 114 & 562 & 4.930 & 5.507 & 197.114 & 319.405 & 0.029 & 1575.370 \\
\hline
\end{tabular}


Cont. Table 2. Number of blocks, total number of SNPS in the blocks, average number SNP / block, standard deviation number of SNP / block, average block size $(\mathrm{Kb})$, standard deviation block size $(\mathrm{Kb})$, maximum block size $(\mathrm{Kb})$ and minimum block size $(\mathrm{Kb})$.

\begin{tabular}{|c|c|c|c|c|c|c|c|c|}
\hline \multicolumn{9}{|c|}{$\mathrm{SSC} 13$} \\
\hline Line & $\begin{array}{c}\text { Number } \\
\text { of } \\
\text { blocks } \\
\end{array}$ & $\begin{array}{c}\text { Total number of } \\
\text { SNPs in the } \\
\text { blocks }\end{array}$ & $\begin{array}{c}\text { Average } \\
\text { number of } \\
\text { SNP/ block } \\
\end{array}$ & $\begin{array}{c}\text { SD number } \\
\text { of SNP/ } \\
\text { block } \\
\end{array}$ & $\begin{array}{l}\text { Average block } \\
\text { size }(\mathrm{Kb})\end{array}$ & $\begin{array}{l}\text { SD block } \\
\text { size }(\mathrm{Kb})\end{array}$ & $\begin{array}{c}\text { Maximum } \\
\text { Block size } \\
(\mathrm{Kb}) \\
\end{array}$ & $\begin{array}{c}\text { Minimum } \\
\text { block size }(\mathrm{Kb})\end{array}$ \\
\hline 1 & 269 & 1,637 & 6.086 & 5.254 & 414.672 & 751.277 & 1.412 & 6663.270 \\
\hline 2 & 231 & 1,606 & 6.952 & 8.179 & 442.527 & 827.449 & 0.362 & 7971.370 \\
\hline 3 & 234 & 1,540 & 6.581 & 8.014 & 437.107 & 838.698 & 0.362 & 7452.140 \\
\hline 4 & 215 & 1,559 & 7.251 & 9.560 & 512.289 & 931.154 & 0.385 & 7197.040 \\
\hline 5 & 280 & 1,594 & 5.693 & 4.964 & 359.720 & 582.458 & 0.162 & 5046.620 \\
\hline 6 & 200 & 1,682 & 8.410 & 9.624 & 575.979 & 959.058 & 0.385 & 5919.680 \\
\hline \multicolumn{9}{|c|}{ SSC14 } \\
\hline Line & $\begin{array}{c}\text { Number } \\
\text { of } \\
\text { blocks }\end{array}$ & $\begin{array}{l}\text { Total number of } \\
\text { SNPs in the } \\
\text { blocks }\end{array}$ & $\begin{array}{c}\text { Average } \\
\text { number of } \\
\text { SNP/ block }\end{array}$ & $\begin{array}{c}\text { Sd number } \\
\text { of SNP/ } \\
\text { block }\end{array}$ & $\begin{array}{l}\text { Average block } \\
\text { size }(\mathrm{Kb})\end{array}$ & $\begin{array}{l}\text { Sd block size } \\
(\mathrm{Kb})\end{array}$ & $\begin{array}{c}\text { Maximum } \\
\text { Block size } \\
(\mathrm{Kb})\end{array}$ & $\begin{array}{c}\text { Minimum } \\
\text { block size }(\mathrm{Kb})\end{array}$ \\
\hline 1 & 249 & 1,815 & 7.289 & 9.957 & 316.472 & 581.274 & 2.595 & 5368.550 \\
\hline 2 & 234 & 1,818 & 7.769 & 11.629 & 356.867 & 712.262 & 0.048 & 8219.920 \\
\hline 3 & 250 & 1,863 & 7.452 & 8.237 & 313.220 & 443.208 & 0.126 & 2625.770 \\
\hline 4 & 197 & 1,855 & 9.416 & 15.588 & 441.016 & 950.879 & 2.181 & 9188.500 \\
\hline 5 & 240 & 1,641 & 6.838 & 7.813 & 285.322 & 423.005 & 2.181 & 3060.990 \\
\hline 6 & 209 & 1,638 & 7.837 & 9.234 & 353.823 & 534.613 & 0.048 & 4893.980 \\
\hline
\end{tabular}


Cont. Table 2. Number of blocks, total number of SNPs in the blocks, average number SNP / block, standard deviation number of SNP / block, average block size $(\mathrm{Kb})$, standard deviation block size $(\mathrm{Kb})$, maximum block size $(\mathrm{Kb})$ and minimum block size $(\mathrm{Kb})$.

\begin{tabular}{|c|c|c|c|c|c|c|c|c|}
\hline \multicolumn{9}{|c|}{ SSC15 } \\
\hline Line & $\begin{array}{c}\text { Number } \\
\text { of } \\
\text { blocks }\end{array}$ & $\begin{array}{c}\text { Total number of } \\
\text { SNPs in the } \\
\text { blocks }\end{array}$ & $\begin{array}{c}\text { Average } \\
\text { number of } \\
\text { SNP/ block } \\
\end{array}$ & $\begin{array}{c}\text { SD number } \\
\text { of SNP/ } \\
\text { block } \\
\end{array}$ & $\begin{array}{l}\text { Average block } \\
\text { size }(\mathrm{Kb})\end{array}$ & $\begin{array}{l}\text { SD block } \\
\text { size }(\mathrm{Kb})\end{array}$ & $\begin{array}{c}\text { Maximum } \\
\text { Block size } \\
(\mathrm{Kb}) \\
\end{array}$ & $\begin{array}{c}\text { Minimum } \\
\text { block size }(\mathrm{Kb})\end{array}$ \\
\hline 1 & 217 & 1,214 & 5.594 & 5.315 & 300.350 & 469.996 & 0.237 & 2297.550 \\
\hline 2 & 188 & 1,072 & 5.702 & 6.187 & 372.998 & 710.677 & 0.666 & 6475.920 \\
\hline 3 & 177 & 963 & 5.441 & 6.004 & 332.160 & 574.888 & 0.237 & 4411.780 \\
\hline 4 & 169 & 1,030 & 6.095 & 5.293 & 420.142 & 789.106 & 0.659 & 6802.560 \\
\hline 5 & 189 & 953 & 5.042 & 5.128 & 286.366 & 503.109 & 0.237 & 3811.530 \\
\hline 6 & 193 & 1,121 & 5.808 & 4.326 & 338.384 & 479.171 & 0.237 & 4107.330 \\
\hline \multicolumn{9}{|c|}{ SSC16 } \\
\hline Line & $\begin{array}{c}\text { Number } \\
\text { of } \\
\text { blocks }\end{array}$ & $\begin{array}{c}\text { Total number of } \\
\text { SNPs in the } \\
\text { blocks }\end{array}$ & $\begin{array}{c}\text { Average } \\
\text { number of } \\
\text { SNP/ block }\end{array}$ & $\begin{array}{l}\text { SD number } \\
\text { of SNP/ } \\
\text { block }\end{array}$ & $\begin{array}{l}\text { Average block } \\
\text { size }(\mathrm{Kb})\end{array}$ & $\begin{array}{l}\text { SD block } \\
\text { size }(\mathrm{Kb})\end{array}$ & $\begin{array}{c}\text { Maximum } \\
\text { Block size } \\
(\mathrm{Kb})\end{array}$ & $\begin{array}{c}\text { Minimum } \\
\text { block size }(\mathrm{Kb})\end{array}$ \\
\hline 1 & 158 & 725 & 4.589 & 2.893 & 193.721 & 254.519 & 1.105 & 1593.400 \\
\hline 2 & 137 & 652 & 4.759 & 3.904 & 217.677 & 341.809 & 0.021 & 2467.150 \\
\hline 3 & 112 & 732 & 6.536 & 8.837 & 357.952 & 679.476 & 0.021 & 4916.010 \\
\hline 4 & 112 & 752 & 6.714 & 7.697 & 364.007 & 652.205 & 0.021 & 4958.950 \\
\hline 5 & 138 & 569 & 4.123 & 2.891 & 161.337 & 235.792 & 0.021 & 1309.500 \\
\hline 6 & 132 & 601 & 4.553 & 2.880 & 192.386 & 273.063 & 0.138 & 1614.610 \\
\hline
\end{tabular}


Cont. Table 2. Number of blocks, total number of SNPs in the blocks, average number SNP / block, standard deviation number of SNP / block, average block size $(\mathrm{Kb})$, standard deviation block size $(\mathrm{Kb})$, maximum block size $(\mathrm{Kb})$ and minimum block size $(\mathrm{Kb})$.

\begin{tabular}{|c|c|c|c|c|c|c|c|c|}
\hline \multicolumn{9}{|c|}{ SSC17 } \\
\hline Line & $\begin{array}{c}\text { Number } \\
\text { of } \\
\text { blocks } \\
\end{array}$ & $\begin{array}{c}\text { Total number of } \\
\text { SNPs in the } \\
\text { blocks }\end{array}$ & $\begin{array}{c}\text { Average } \\
\text { number of } \\
\text { SNP/ block } \\
\end{array}$ & $\begin{array}{c}\text { SD number } \\
\text { of SNP/ } \\
\text { block } \\
\end{array}$ & $\begin{array}{l}\text { Average block } \\
\text { size }(\mathrm{Kb})\end{array}$ & $\begin{array}{l}\text { SD block } \\
\text { size }(\mathrm{Kb})\end{array}$ & $\begin{array}{c}\text { Maximum } \\
\text { Block size } \\
(\mathrm{Kb}) \\
\end{array}$ & $\begin{array}{c}\text { Minimum } \\
\text { block size }(\mathrm{Kb})\end{array}$ \\
\hline 1 & 125 & 582 & 4.656 & 4.080 & 175.077 & 266.206 & 0.101 & 2397.810 \\
\hline 2 & 111 & 526 & 4.739 & 3.521 & 180.561 & 213.345 & 0.180 & 1062.780 \\
\hline 3 & 121 & 667 & 5.512 & 3.841 & 210.320 & 258.798 & 1.046 & 2141.670 \\
\hline 4 & 112 & 655 & 5.848 & 4.485 & 255.349 & 310.623 & 1.453 & 1831.970 \\
\hline 5 & 120 & 540 & 4.500 & 2.948 & 153.917 & 173.673 & 1.453 & 770.013 \\
\hline 6 & 104 & 607 & 5.837 & 5.299 & 247.715 & 374.064 & 1.470 & 2413.900 \\
\hline \multicolumn{9}{|c|}{ SSC18 } \\
\hline Line & $\begin{array}{c}\text { Number } \\
\text { of } \\
\text { blocks }\end{array}$ & $\begin{array}{l}\text { Total number of } \\
\text { SNPs in the } \\
\text { blocks }\end{array}$ & $\begin{array}{c}\text { Average } \\
\text { number of } \\
\text { SNP/ block }\end{array}$ & $\begin{array}{c}\text { Sd number } \\
\text { of SNP/ } \\
\text { block }\end{array}$ & $\begin{array}{l}\text { Average block } \\
\text { size }(\mathrm{Kb})\end{array}$ & $\begin{array}{l}\text { Sd block size } \\
(\mathrm{Kb})\end{array}$ & $\begin{array}{c}\text { Maximum } \\
\text { Block size } \\
(\mathrm{Kb})\end{array}$ & $\begin{array}{c}\text { Minimum } \\
\text { block size }(\mathrm{Kb})\end{array}$ \\
\hline 1 & 134 & 539 & 4.022 & 2.716 & 153.993 & 201.731 & 1.557 & 1109.560 \\
\hline 2 & 97 & 446 & 4.598 & 3.249 & 209.104 & 285.731 & 0.885 & 1596.960 \\
\hline 3 & 114 & 480 & 4.211 & 3.107 & 139.869 & 193.024 & 0.424 & 876.766 \\
\hline 4 & 109 & 530 & 4.862 & 3.614 & 197.633 & 244.487 & 0.424 & 1271.230 \\
\hline 5 & 94 & 386 & 4.106 & 2.321 & 182.581 & 249.660 & 0.412 & 1089.180 \\
\hline 6 & & 472 & 4.627 & 3.063 & 199.626 & 272.014 & 0.412 & 1569.850 \\
\hline
\end{tabular}


Table 3. Adjusted average block size by line and autossome.

\begin{tabular}{|c|c|c|}
\hline Line & $\begin{array}{l}\text { Adjusted average } \\
\text { block size }(\mathrm{Kb})^{*}\end{array}$ & $\begin{array}{c}\text { Standard } \\
\text { error }\end{array}$ \\
\hline \multicolumn{3}{|c|}{ SSC1 } \\
\hline 1 & 416.725 & 17.371 \\
\hline 2 & 395.735 & 17.477 \\
\hline 3 & 432.681 & 18.108 \\
\hline 4 & 400.858 & 17.896 \\
\hline 5 & 386.950 & 17.271 \\
\hline 6 & 390.773 & 17.352 \\
\hline \multicolumn{3}{|c|}{ SSC2 } \\
\hline 1 & 256.798 & 20.608 \\
\hline 2 & 285.172 & 21.850 \\
\hline 3 & 276.505 & 20.705 \\
\hline 4 & 299.072 & 22.991 \\
\hline 5 & 263.276 & 19.944 \\
\hline 6 & 237.898 & 21.625 \\
\hline \multicolumn{3}{|c|}{ SSC3 } \\
\hline 1 & 234.488 & 14.546 \\
\hline 2 & 235.102 & 15.463 \\
\hline 3 & 236.986 & 14.817 \\
\hline 4 & 213.693 & 14.447 \\
\hline 5 & 200.838 & 14.005 \\
\hline 6 & 210.370 & 15.166 \\
\hline \multicolumn{3}{|c|}{ SSC4 } \\
\hline 1 & 238.578 & 13.593 \\
\hline 2 & 243.602 & 15.563 \\
\hline 3 & 228.787 & 15.435 \\
\hline 4 & 245.262 & 15.343 \\
\hline 5 & 222.676 & 15.213 \\
\hline 6 & 245.407 & 16.273 \\
\hline \multicolumn{3}{|c|}{ SSC5 } \\
\hline 1 & 238.835 & 17.604 \\
\hline 2 & 241.778 & 17.348 \\
\hline 3 & 250.421 & 17.995 \\
\hline 4 & 287.993 & 17.847 \\
\hline 5 & 253.199 & 17.092 \\
\hline 6 & 240.496 & 18.404 \\
\hline
\end{tabular}

*The average was adjusted by the number of SNPs in the block 
Cont. Table 3. Adjusted average block size by line and autossome.

\begin{tabular}{|c|c|c|}
\hline Line & $\begin{array}{c}\text { Adjusted average } \\
\text { block size }(\mathrm{Kb}) \\
\end{array}$ & $\begin{array}{c}\text { Standard } \\
\text { error }\end{array}$ \\
\hline \multicolumn{3}{|c|}{ SSC6 } \\
\hline 1 & 303.685 & 17.864 \\
\hline 2 & 301.237 & 18.532 \\
\hline 3 & 299.952 & 18.224 \\
\hline 4 & 305.212 & 19.232 \\
\hline 5 & 295.135 & 18.934 \\
\hline 6 & 271.971 & 19.637 \\
\hline \multicolumn{3}{|c|}{ SSC7 } \\
\hline 1 & 270.375 & 15.783 \\
\hline 2 & 255.870 & 15.487 \\
\hline 3 & 239.774 & 16.308 \\
\hline 4 & 284.896 & 15.861 \\
\hline 5 & 252.734 & 15.415 \\
\hline 6 & 247.305 & 16.187 \\
\hline \multicolumn{3}{|c|}{ SSC8 } \\
\hline 1 & 328.656 & 33.750 \\
\hline 2 & 317.733 & 36.357 \\
\hline 3 & 343.390 & 33.341 \\
\hline 4 & 355.400 & 39.112 \\
\hline 5 & 372.400 & 37.862 \\
\hline 6 & 321.202 & 35.659 \\
\hline \multicolumn{3}{|c|}{ SSC9 } \\
\hline 1 & 265.944 & 13.194 \\
\hline 2 & 236.214 & 13.857 \\
\hline 3 & 228.322 & 13.486 \\
\hline 4 & 243.718 & 14.009 \\
\hline 5 & 226.304 & 13.508 \\
\hline 6 & 263.462 & 14.654 \\
\hline \multicolumn{3}{|c|}{ SSC10 } \\
\hline 1 & 185.333 & 15.983 \\
\hline 2 & 175.529 & 16.872 \\
\hline 3 & 177.651 & 17.162 \\
\hline 4 & 208.650 & 16.969 \\
\hline 5 & 162.673 & 16.725 \\
\hline 6 & 177.062 & 16.711 \\
\hline
\end{tabular}

*The average was adjusted by the number of SNPs in the block 
Cont. Table 3. Adjusted average block size by line and autossome.

\begin{tabular}{|c|c|c|}
\hline Line & $\begin{array}{l}\text { Adjusted average } \\
\text { block size }(\mathrm{Kb})\end{array}$ & $\begin{array}{c}\text { Standard } \\
\text { error }\end{array}$ \\
\hline \multicolumn{3}{|c|}{ SSC11 } \\
\hline 1 & 219.823 & 14.342 \\
\hline 2 & 236.170 & 15.555 \\
\hline 3 & 234.750 & 15.496 \\
\hline 4 & 241.795 & 15.379 \\
\hline 5 & 225.582 & 14.590 \\
\hline 6 & 206.310 & 16.632 \\
\hline \multicolumn{3}{|c|}{ SSC12 } \\
\hline 1 & 136.859 & 10.887 \\
\hline 2 & 147.691 & 11.610 \\
\hline 3 & 133.219 & 11.007 \\
\hline 4 & 139.734 & 11.314 \\
\hline 5 & 134.494 & 10.996 \\
\hline 6 & 150.340 & 12.446 \\
\hline \multicolumn{3}{|c|}{ SSC13 } \\
\hline 1 & 474.155 & 24.723 \\
\hline 2 & 422.075 & 26.663 \\
\hline 3 & 450.881 & 26.490 \\
\hline 4 & 464.286 & 27.645 \\
\hline 5 & 455.408 & 24.260 \\
\hline 6 & 421.120 & 28.750 \\
\hline \multicolumn{3}{|c|}{ SSC14 } \\
\hline 1 & 340.068 & 11.613 \\
\hline 2 & 353.449 & 11.978 \\
\hline 3 & 327.652 & 11.589 \\
\hline 4 & 344.918 & 13.079 \\
\hline 5 & 334.333 & 11.834 \\
\hline 6 & 346.573 & 12.674 \\
\hline \multicolumn{3}{|c|}{ SSC15 } \\
\hline 1 & 301.371 & 27.629 \\
\hline 2 & 365.409 & 29.684 \\
\hline 3 & 345.481 & 30.594 \\
\hline 4 & 381.161 & 31.326 \\
\hline 5 & 331.544 & 29.632 \\
\hline 6 & 322.306 & 29.300 \\
\hline
\end{tabular}

*The average was adjusted by the number of SNPs in the block 
Cont. Table 3. Adjusted average block size by line and autossome.

\begin{tabular}{ccc}
\hline Line & $\begin{array}{c}\text { Adjusted average } \\
\text { block size }(\mathrm{Kb})\end{array}$ & $\begin{array}{c}\text { Standard } \\
\text { error }\end{array}$ \\
\hline \hline \multicolumn{3}{c}{ SSC16 } \\
\hline 1 & 231.898 & 15.499 \\
2 & 243.344 & 16.634 \\
3 & 253.284 & 18.490 \\
4 & 246.239 & 18.517 \\
5 & 233.658 & 16.620 \\
6 & 233.173 & 16.956 \\
\hline \multicolumn{3}{c}{ SSC17 } \\
\hline 1 & 204.661 & 11.679 \\
2 & 205.304 & 12.387 \\
3 & 189.796 & 11.862 \\
4 & 215.176 & 12.350 \\
5 & 192.628 & 11.931 \\
6 & 208.225 & 12.813 \\
\hline \multicolumn{3}{c}{ SSC18 } \\
\hline 1 & 177.337 & 12.354 \\
2 & 195.822 & 14.504 \\
3 & 151.242 & 13.378 \\
4 & 167.523 & 13.705 \\
5 & 200.581 & 14.737 \\
6 & 184.466 & 14.145 \\
\hline
\end{tabular}

*The average was adjusted by the number of SNPs in the block 
Table 4. Contrast between lines, standard error and P-value by autossome.

\begin{tabular}{|c|c|c|c|}
\hline Contrast & $\begin{array}{l}\text { Contrast } \\
\text { Estimate }\end{array}$ & $\begin{array}{c}\text { Standard } \\
\text { Error }\end{array}$ & P-value \\
\hline \multicolumn{4}{|c|}{ SSC1 } \\
\hline 1 vs 2 & 20.991 & 24.642 & 0.394 \\
\hline 1 vs 3 & -15.956 & 25.095 & 0.525 \\
\hline 1 vs 4 & 15.867 & 24.940 & 0.525 \\
\hline 1 vs 5 & 29.775 & 24.494 & 0.224 \\
\hline 1 vs 6 & 25.952 & 24.555 & 0.291 \\
\hline 2 vs 3 & -36.946 & 25.166 & 0.142 \\
\hline 2 vs 4 & -5.123 & 25.014 & 0.838 \\
\hline 2 vs 5 & 8.784 & 24.571 & 0.721 \\
\hline 2 vs 6 & 4.961 & 24.627 & 0.840 \\
\hline 3 vs 4 & 31.823 & 25.461 & 0.211 \\
\hline 3 vs 5 & 45.731 & 25.028 & 0.068 \\
\hline 3 vs 6 & 41.908 & 25.077 & 0.095 \\
\hline 4 vs 5 & 13.908 & 24.870 & 0.576 \\
\hline 4 vs 6 & 10.085 & 24.929 & 0.686 \\
\hline 5 vs 6 & -3.823 & 24.486 & 0.876 \\
\hline Boar x Sow & -24.903 & 43.073 & 0.563 \\
\hline \multicolumn{4}{|c|}{ SSC2 } \\
\hline 1 vs 2 & -28.373 & 30.035 & 0.345 \\
\hline 1 vs 3 & -19.706 & 29.213 & 0.500 \\
\hline $1 \mathrm{vs} 4$ & -42.274 & 30.875 & 0.171 \\
\hline 1 vs 5 & -6.478 & 28.679 & 0.821 \\
\hline 1 vs 6 & 18.900 & 29.872 & 0.527 \\
\hline 2 vs 3 & 8.667 & 30.120 & 0.774 \\
\hline 2 vs 4 & -13.900 & 31.683 & 0.661 \\
\hline 2 vs 5 & 21.895 & 29.611 & 0.460 \\
\hline 2 vs 6 & 47.274 & 30.735 & 0.124 \\
\hline 3 vs 4 & -22.567 & 31.001 & 0.467 \\
\hline 3 vs 5 & 13.228 & 28.701 & 0.645 \\
\hline 3 vs 6 & 38.607 & 29.951 & 0.198 \\
\hline 4 vs 5 & 35.796 & 30.530 & 0.241 \\
\hline 4 vs 6 & 61.174 & 31.539 & 0.053 \\
\hline 5 vs 6 & 25.378 & 29.437 & 0.389 \\
\hline Boar x Sow & -8.228 & 52.180 & 0.875 \\
\hline
\end{tabular}


Cont. Table 4. Contrast between lines, standard error and P-value by autossome.

\begin{tabular}{|c|c|c|c|}
\hline Contrast & $\begin{array}{l}\text { Contrast } \\
\text { Estimate }\end{array}$ & $\begin{array}{l}\text { Standard } \\
\text { Error }\end{array}$ & P-value \\
\hline \multicolumn{4}{|c|}{ SSC3 } \\
\hline 1 vs 2 & -0.614 & 21.242 & 0.977 \\
\hline 1 vs 3 & -2.497 & 20.770 & 0.904 \\
\hline 1 vs 4 & 20.796 & 20.501 & 0.311 \\
\hline 1 vs 5 & 33.650 & 20.178 & 0.096 \\
\hline 1 vs 6 & 24.119 & 21.016 & 0.251 \\
\hline 2 vs 3 & -1.883 & 21.395 & 0.930 \\
\hline 2 vs 4 & 21.409 & 21.163 & 0.312 \\
\hline 2 vs 5 & 34.264 & 20.915 & 0.102 \\
\hline 2 vs 6 & 24.733 & 21.653 & 0.254 \\
\hline 3 vs 4 & 23.293 & 20.695 & 0.261 \\
\hline 3 vs 5 & 36.148 & 20.413 & 0.077 \\
\hline 3 vs 6 & 26.616 & 21.200 & 0.210 \\
\hline 4 vs 5 & 12.855 & 20.120 & 0.523 \\
\hline 4 vs 6 & 3.323 & 20.946 & 0.874 \\
\hline 5 vs 6 & -9.532 & 20.651 & 0.644 \\
\hline Boar x Sow & 9.381 & 36.103 & 0.795 \\
\hline \multicolumn{4}{|c|}{ SSC4 } \\
\hline 1 vs 2 & -5.024 & 20.660 & 0.808 \\
\hline 1 vs 3 & 9.791 & 20.577 & 0.634 \\
\hline 1 vs 4 & -6.684 & 20.511 & 0.745 \\
\hline 1 vs 5 & 15.903 & 20.395 & 0.436 \\
\hline 1 vs 6 & -6.828 & 21.217 & 0.748 \\
\hline 2 vs 3 & 14.815 & 21.921 & 0.499 \\
\hline 2 vs 4 & -1.660 & 21.856 & 0.939 \\
\hline 2 vs 5 & 20.926 & 21.762 & 0.336 \\
\hline 2 vs 6 & -1.805 & 22.520 & 0.936 \\
\hline 3 vs 4 & -16.475 & 21.757 & 0.449 \\
\hline 3 vs 5 & 6.111 & 21.675 & 0.778 \\
\hline 3 vs 6 & -16.620 & 22.423 & 0.459 \\
\hline 4 vs 5 & 22.586 & 21.611 & 0.296 \\
\hline 4 vs 6 & -0.145 & 22.357 & 0.995 \\
\hline 5 vs 6 & -22.731 & 22.281 & 0.308 \\
\hline Boar x Sow & -14.600 & 37.424 & 0.697 \\
\hline
\end{tabular}


Cont. Table 4. Contrast between lines, standard error and P-value by autossome.

\begin{tabular}{|c|c|c|c|}
\hline Contrast & $\begin{array}{l}\text { Contrast } \\
\text { Estimate }\end{array}$ & $\begin{array}{l}\text { Standard } \\
\text { Error }\end{array}$ & $\mathrm{P}$-value \\
\hline \multicolumn{4}{|c|}{ SSC5 } \\
\hline 1 vs 2 & -2.944 & 24.715 & 0.905 \\
\hline 1 vs 3 & -11.587 & 25.175 & 0.645 \\
\hline 1 vs 4 & -49.159 & 25.067 & 0.050 \\
\hline 1 vs 5 & -14.364 & 24.538 & 0.558 \\
\hline 1 vs 6 & -1.661 & 25.467 & 0.948 \\
\hline 2 vs 3 & -8.643 & 25.002 & 0.730 \\
\hline 2 vs 4 & -46.215 & 24.876 & 0.063 \\
\hline 2 vs 5 & -11.420 & 24.369 & 0.639 \\
\hline 2 vs 6 & 1.282 & 25.285 & 0.960 \\
\hline 3 vs 4 & -37.572 & 25.366 & 0.139 \\
\hline 3 vs 5 & -2.777 & 24.792 & 0.911 \\
\hline 3 vs 6 & 9.926 & 25.750 & 0.700 \\
\hline 4 vs 5 & 34.795 & 24.761 & 0.160 \\
\hline 4 vs 6 & 47.498 & 25.617 & 0.064 \\
\hline 5 vs 6 & 12.703 & 25.141 & 0.613 \\
\hline Boar x Sow & -45.099 & 43.408 & 0.299 \\
\hline \multicolumn{4}{|c|}{ SSC6 } \\
\hline 1 vs 2 & 2.448 & 25.740 & 0.924 \\
\hline 1 vs 3 & 3.733 & 25.519 & 0.884 \\
\hline 1 vs 4 & -1.527 & 26.249 & 0.954 \\
\hline 1 vs 5 & 8.550 & 26.031 & 0.743 \\
\hline 1 vs 6 & 31.714 & 26.547 & 0.232 \\
\hline 2 vs 3 & 1.286 & 25.991 & 0.961 \\
\hline 2 vs 4 & -3.974 & 26.715 & 0.882 \\
\hline 2 vs 5 & 6.102 & 26.487 & 0.818 \\
\hline 2 vs 6 & 29.267 & 27.008 & 0.279 \\
\hline 3 vs 4 & -5.260 & 26.495 & 0.843 \\
\hline 3 vs 5 & 4.817 & 26.279 & 0.855 \\
\hline 3 vs 6 & 27.981 & 26.790 & 0.296 \\
\hline 4 vs 5 & 10.077 & 26.995 & 0.709 \\
\hline 4 vs 6 & 33.241 & 27.478 & 0.227 \\
\hline 5 vs 6 & 23.164 & 27.286 & 0.396 \\
\hline Boar x Sow & 22.923 & 45.946 & 0.618 \\
\hline
\end{tabular}


Cont. Table 4. Contrast between lines, standard error and P-value by autossome.

\begin{tabular}{|c|c|c|c|}
\hline Contrast & $\begin{array}{l}\text { Contrast } \\
\text { Estimate }\end{array}$ & $\begin{array}{c}\text { Standard } \\
\text { Error }\end{array}$ & P-value \\
\hline \multicolumn{4}{|c|}{ SSC7 } \\
\hline 1 vs 2 & 14.505 & 22.113 & 0.512 \\
\hline 1 vs 3 & 30.601 & 22.694 & 0.178 \\
\hline 1 vs 4 & -14.521 & 22.376 & 0.516 \\
\hline 1 vs 5 & 17.641 & 22.061 & 0.424 \\
\hline 1 vs 6 & 23.070 & 22.609 & 0.308 \\
\hline 2 vs 3 & 16.097 & 22.493 & 0.474 \\
\hline 2 vs 4 & -29.025 & 22.170 & 0.191 \\
\hline 2 vs 5 & 3.136 & 21.854 & 0.886 \\
\hline 2 vs 6 & 8.565 & 22.398 & 0.702 \\
\hline 3 vs 4 & -45.122 & 22.748 & 0.048 \\
\hline 3 vs 5 & -12.960 & 22.438 & 0.564 \\
\hline 3 vs 6 & -7.531 & 22.982 & 0.743 \\
\hline 4 vs 5 & 32.162 & 22.116 & 0.146 \\
\hline 4 vs 6 & 37.591 & 22.666 & 0.097 \\
\hline 5 vs 6 & 5.429 & 22.356 & 0.808 \\
\hline Boar x Sow & 7.005 & 38.804 & 0.857 \\
\hline \multicolumn{4}{|c|}{ SSC8 } \\
\hline 1 vs 2 & 10.923 & 49.600 & 0.826 \\
\hline 1 vs 3 & -14.734 & 47.455 & 0.756 \\
\hline 1 vs 4 & -26.743 & 51.643 & 0.605 \\
\hline 1 vs 5 & -43.743 & 50.731 & 0.389 \\
\hline 1 vs 6 & 7.454 & 49.099 & 0.879 \\
\hline 2 vs 3 & -25.657 & 49.378 & 0.603 \\
\hline 2 vs 4 & -37.666 & 53.336 & 0.480 \\
\hline 2 vs 5 & -54.667 & 52.530 & 0.298 \\
\hline 2 vs 6 & -3.469 & 50.926 & 0.946 \\
\hline 3 vs 4 & -12.010 & 51.512 & 0.816 \\
\hline 3 vs 5 & -29.010 & 50.380 & 0.565 \\
\hline 3 vs 6 & 22.188 & 48.816 & 0.650 \\
\hline 4 vs 5 & -17.000 & 54.530 & 0.755 \\
\hline 4 vs 6 & 34.198 & 52.930 & 0.518 \\
\hline 5 vs 6 & 51.198 & 52.009 & 0.325 \\
\hline Boar x Sow & -1.202 & 88.269 & 0.989 \\
\hline
\end{tabular}


Cont. Table 4. Contrast between lines, standard error and P-value by autossome.

\begin{tabular}{|c|c|c|c|}
\hline Contrast & $\begin{array}{l}\text { Contrast } \\
\text { Estimate }\end{array}$ & $\begin{array}{l}\text { Standard } \\
\text { Error }\end{array}$ & $\mathrm{P}$-value \\
\hline \multicolumn{4}{|c|}{ SSC9 } \\
\hline 1 vs 2 & 29.730 & 19.143 & 0.121 \\
\hline 1 vs 3 & 37.622 & 18.857 & 0.046 \\
\hline 1 vs 4 & 22.226 & 19.261 & 0.249 \\
\hline 1 vs 5 & 39.640 & 18.861 & 0.036 \\
\hline 1 vs 6 & 2.482 & 19.739 & 0.900 \\
\hline 2 vs 3 & 7.891 & 19.343 & 0.683 \\
\hline 2 vs 4 & -7.504 & 19.690 & 0.703 \\
\hline 2 vs 5 & 9.910 & 19.368 & 0.609 \\
\hline 2 vs 6 & -27.248 & 20.152 & 0.177 \\
\hline 3 vs 4 & -15.396 & 19.458 & 0.429 \\
\hline 3 vs 5 & 2.019 & 19.070 & 0.916 \\
\hline 3 vs 6 & -35.140 & 19.931 & 0.078 \\
\hline 4 vs 5 & 17.414 & 19.491 & 0.372 \\
\hline 4 vs 6 & -19.744 & 20.244 & 0.330 \\
\hline 5 vs 6 & -37.158 & 19.966 & 0.063 \\
\hline Boar x Sow & -7.041 & 33.814 & 0.835 \\
\hline \multicolumn{4}{|c|}{ SSC10 } \\
\hline 1 vs 2 & 9.804 & 23.213 & 0.673 \\
\hline 1 vs 3 & 7.682 & 23.457 & 0.743 \\
\hline $1 \mathrm{vs} 4$ & -23.317 & 23.380 & 0.319 \\
\hline 1 vs 5 & 22.660 & 23.107 & 0.327 \\
\hline 1 vs 6 & 8.272 & 23.136 & 0.721 \\
\hline 2 vs 3 & -2.122 & 24.071 & 0.930 \\
\hline 2 vs 4 & -33.121 & 23.992 & 0.168 \\
\hline 2 vs 5 & 12.856 & 23.732 & 0.588 \\
\hline 2 vs 6 & -1.533 & 23.758 & 0.949 \\
\hline 3 vs 4 & -30.999 & 24.122 & 0.199 \\
\hline 3 vs 5 & 14.978 & 23.968 & 0.532 \\
\hline 3 vs 6 & 0.590 & 23.952 & 0.980 \\
\hline 4 vs 5 & 45.977 & 23.889 & 0.055 \\
\hline 4 vs 6 & 31.588 & 23.788 & 0.185 \\
\hline 5 vs 6 & -14.389 & 23.654 & 0.543 \\
\hline Boar x Sow & -39.828 & 41.217 & 0.334 \\
\hline
\end{tabular}


Cont. Table 4. Contrast between lines, standard error and P-value by autossome.

\begin{tabular}{|c|c|c|c|}
\hline Contrast & $\begin{array}{l}\text { Contrast } \\
\text { Estimate }\end{array}$ & $\begin{array}{c}\text { Standard } \\
\text { Error }\end{array}$ & $\mathrm{P}$-value \\
\hline \multicolumn{4}{|c|}{ SSC11 } \\
\hline 1 vs 2 & -16.347 & 21.157 & 0.440 \\
\hline 1 vs 3 & -14.927 & 21.118 & 0.480 \\
\hline 1 vs 4 & -21.972 & 21.031 & 0.296 \\
\hline 1 vs 5 & -5.759 & 20.449 & 0.778 \\
\hline 1 vs 6 & 13.512 & 21.975 & 0.539 \\
\hline 2 vs 3 & 1.420 & 21.957 & 0.948 \\
\hline 2 vs 4 & -5.625 & 21.874 & 0.797 \\
\hline 2 vs 5 & 10.588 & 21.325 & 0.620 \\
\hline 2 vs 6 & 29.859 & 22.774 & 0.190 \\
\hline 3 vs 4 & -7.045 & 21.831 & 0.747 \\
\hline 3 vs 5 & 9.168 & 21.290 & 0.667 \\
\hline 3 vs 6 & 28.439 & 22.725 & 0.211 \\
\hline 4 vs 5 & 16.213 & 21.203 & 0.445 \\
\hline 4 vs 6 & 35.484 & 22.647 & 0.118 \\
\hline 5 vs 6 & 19.271 & 22.147 & 0.384 \\
\hline Boar x Sow & -1.280 & 37.646 & 0.973 \\
\hline \multicolumn{4}{|c|}{$\mathrm{SSC} 12$} \\
\hline 1 vs 2 & -10.832 & 15.916 & 0.496 \\
\hline 1 vs 3 & 3.641 & 15.469 & 0.814 \\
\hline 1 vs 4 & -2.874 & 15.709 & 0.855 \\
\hline 1 vs 5 & 2.366 & 15.469 & 0.878 \\
\hline 1 vs 6 & -13.480 & 16.559 & 0.416 \\
\hline 2 vs 3 & 14.473 & 15.998 & 0.366 \\
\hline 2 vs 4 & 7.958 & 16.212 & 0.624 \\
\hline 2 vs 5 & 13.198 & 15.991 & 0.409 \\
\hline 2 vs 6 & -2.648 & 17.021 & 0.876 \\
\hline 3 vs 4 & -6.515 & 15.796 & 0.680 \\
\hline 3 vs 5 & -1.275 & 15.550 & 0.935 \\
\hline 3 vs 6 & -17.121 & 16.651 & 0.304 \\
\hline 4 vs 5 & 5.240 & 15.782 & 0.740 \\
\hline 4 vs 6 & -10.606 & 16.800 & 0.528 \\
\hline 5 vs 6 & -15.846 & 16.624 & 0.341 \\
\hline Boar x Sow & -4.248 & 27.905 & 0.879 \\
\hline
\end{tabular}


Cont. Table 4. Contrast between lines, standard error and P-value by autossome.

\begin{tabular}{|c|c|c|c|}
\hline Contrast & $\begin{array}{l}\text { Contrast } \\
\text { Estimate }\end{array}$ & $\begin{array}{l}\text { Standard } \\
\text { Error }\end{array}$ & P-value \\
\hline \multicolumn{4}{|c|}{ SSC13 } \\
\hline 1 vs 2 & 52.079 & 36.369 & 0.152 \\
\hline 1 vs 3 & 23.273 & 36.229 & 0.521 \\
\hline 1 vs 4 & 9.868 & 37.105 & 0.790 \\
\hline 1 vs 5 & 18.746 & 34.599 & 0.588 \\
\hline 1 vs 6 & 53.034 & 37.975 & 0.163 \\
\hline 2 vs 3 & -28.806 & 37.587 & 0.444 \\
\hline 2 vs 4 & -42.211 & 38.402 & 0.272 \\
\hline 2 vs 5 & -33.333 & 36.061 & 0.355 \\
\hline 2 vs 6 & 0.955 & 39.192 & 0.981 \\
\hline 3 vs 4 & -13.405 & 38.292 & 0.726 \\
\hline 3 vs 5 & -4.527 & 35.912 & 0.900 \\
\hline 3 vs 6 & 29.761 & 39.106 & 0.447 \\
\hline 4 vs 5 & 8.878 & 36.810 & 0.809 \\
\hline 4 vs 6 & 43.166 & 39.842 & 0.279 \\
\hline 5 vs 6 & 34.288 & 37.710 & 0.363 \\
\hline Boar x Sow & 15.350 & 64.950 & 0.813 \\
\hline \multicolumn{4}{|c|}{ SSC14 } \\
\hline 1 vs 2 & -13.381 & 16.684 & 0.423 \\
\hline 1 vs 3 & 12.415 & 16.405 & 0.449 \\
\hline 1 vs 4 & -4.851 & 17.499 & 0.782 \\
\hline 1 vs 5 & 5.734 & 16.576 & 0.729 \\
\hline 1 vs 6 & -6.505 & 17.191 & 0.705 \\
\hline 2 vs 3 & 25.796 & 16.667 & 0.122 \\
\hline 2 vs 4 & 8.530 & 17.733 & 0.631 \\
\hline 2 vs 5 & 19.115 & 16.839 & 0.256 \\
\hline 2 vs 6 & 6.876 & 17.438 & 0.693 \\
\hline 3 vs 4 & -17.266 & 17.480 & 0.323 \\
\hline 3 vs 5 & -6.681 & 16.560 & 0.687 \\
\hline 3 vs 6 & -18.921 & 17.174 & 0.271 \\
\hline 4 vs 5 & 10.585 & 17.657 & 0.549 \\
\hline 4 vs 6 & -1.654 & 18.210 & 0.928 \\
\hline 5 vs 6 & -12.240 & 17.342 & 0.480 \\
\hline Boar x Sow & 8.706 & 29.753 & 0.770 \\
\hline
\end{tabular}


Cont. Table 4. Contrast between lines, standard error and P-value by autossome.

\begin{tabular}{|c|c|c|c|}
\hline Contrast & $\begin{array}{l}\text { Contrast } \\
\text { Estimate }\end{array}$ & $\begin{array}{l}\text { Standard } \\
\text { Error }\end{array}$ & $\mathrm{P}$-value \\
\hline \multicolumn{4}{|c|}{ SSC15 } \\
\hline 1 vs 2 & -64.038 & 40.552 & 0.115 \\
\hline 1 vs 3 & -44.109 & 41.223 & 0.285 \\
\hline 1 vs 4 & -79.789 & 41.770 & 0.056 \\
\hline 1 vs 5 & -30.172 & 40.513 & 0.457 \\
\hline 1 vs 6 & -20.934 & 40.272 & 0.603 \\
\hline 2 vs 3 & 19.929 & 42.630 & 0.640 \\
\hline 2 vs 4 & -15.751 & 43.151 & 0.715 \\
\hline 2 vs 5 & 33.866 & 41.949 & 0.420 \\
\hline 2 vs 6 & 43.104 & 41.706 & 0.302 \\
\hline 3 vs 4 & -35.680 & 43.797 & 0.415 \\
\hline 3 vs 5 & 13.937 & 42.580 & 0.743 \\
\hline 3 vs 6 & 23.175 & 42.365 & 0.584 \\
\hline 4 vs 5 & 49.617 & 43.153 & 0.250 \\
\hline 4 vs 6 & 58.855 & 42.882 & 0.170 \\
\hline 5 vs 6 & 9.238 & 41.685 & 0.825 \\
\hline Boar x Sow & -50.623 & 72.803 & 0.487 \\
\hline \multicolumn{4}{|c|}{ SSC16 } \\
\hline 1 vs 2 & -11.446 & 22.721 & 0.615 \\
\hline 1 vs 3 & -21.386 & 24.182 & 0.377 \\
\hline 1 vs 4 & -14.341 & 24.210 & 0.554 \\
\hline 1 vs 5 & -1.760 & 22.684 & 0.938 \\
\hline 1 vs 6 & -1.275 & 22.949 & 0.956 \\
\hline 2 vs 3 & -9.940 & 24.907 & 0.690 \\
\hline 2 vs 4 & -2.894 & 24.932 & 0.908 \\
\hline 2 vs 5 & 9.686 & 23.488 & 0.680 \\
\hline 2 vs 6 & 10.171 & 23.738 & 0.668 \\
\hline 3 vs 4 & 7.045 & 26.008 & 0.787 \\
\hline 3 vs 5 & 19.626 & 24.964 & 0.432 \\
\hline 3 vs 6 & 20.111 & 25.145 & 0.424 \\
\hline 4 vs 5 & 12.581 & 24.997 & 0.615 \\
\hline 4 vs 6 & 13.066 & 25.172 & 0.604 \\
\hline 5 vs 6 & 0.485 & 23.701 & 0.984 \\
\hline Boar x Sow & -23.796 & 42.285 & 0.574 \\
\hline
\end{tabular}


Cont. Table 4. Contrast between lines, standard error and P-value by autossome.

\begin{tabular}{|c|c|c|c|}
\hline Contrast & $\begin{array}{l}\text { Contrast } \\
\text { Estimate }\end{array}$ & $\begin{array}{c}\text { Standard } \\
\text { Error }\end{array}$ & P-value \\
\hline \multicolumn{4}{|c|}{ SSC17 } \\
\hline 1 vs 2 & -0.643 & 17.006 & 0.970 \\
\hline 1 vs 3 & 14.865 & 16.662 & 0.373 \\
\hline 1 vs 4 & -10.515 & 17.028 & 0.537 \\
\hline 1 vs 5 & 12.033 & 16.666 & 0.471 \\
\hline 1 vs 6 & -3.564 & 17.367 & 0.837 \\
\hline 2 vs 3 & 15.508 & 17.164 & 0.367 \\
\hline 2 vs 4 & -9.872 & 17.517 & 0.573 \\
\hline 2 vs 5 & 12.676 & 17.174 & 0.461 \\
\hline 2 vs 6 & -2.921 & 17.846 & 0.870 \\
\hline 3 vs 4 & -25.380 & 17.103 & 0.138 \\
\hline 3 vs 5 & -2.832 & 16.845 & 0.867 \\
\hline 3 vs 6 & -18.429 & 17.440 & 0.291 \\
\hline 4 vs 5 & 22.548 & 17.211 & 0.191 \\
\hline 4 vs 6 & 6.951 & 17.757 & 0.696 \\
\hline 5 vs 6 & -15.597 & 17.546 & 0.374 \\
\hline Boar x Sow & -10.604 & 30.051 & 0.724 \\
\hline \multicolumn{4}{|c|}{ SSC18 } \\
\hline 1 vs 2 & -18.485 & 19.066 & 0.333 \\
\hline 1 vs 3 & 26.096 & 18.197 & 0.152 \\
\hline 1 vs 4 & 9.814 & 18.484 & 0.596 \\
\hline 1 vs 5 & -23.243 & 19.212 & 0.227 \\
\hline 1 vs 6 & -7.129 & 18.797 & 0.705 \\
\hline 2 vs 3 & 44.580 & 19.738 & 0.024 \\
\hline 2 vs 4 & 28.299 & 19.938 & 0.156 \\
\hline 2 vs 5 & -4.759 & 20.687 & 0.818 \\
\hline 2 vs 6 & 11.356 & 20.251 & 0.575 \\
\hline 3 vs 4 & -16.282 & 19.167 & 0.396 \\
\hline 3 vs 5 & -49.339 & 19.895 & 0.013 \\
\hline 3 vs 6 & -33.225 & 19.477 & 0.089 \\
\hline 4 vs 5 & -33.058 & 20.148 & 0.101 \\
\hline 4 vs 6 & -16.943 & 19.676 & 0.389 \\
\hline 5 vs 6 & 16.114 & 20.439 & 0.431 \\
\hline Boar x Sow & 70.509 & 33.887 & 0.038 \\
\hline
\end{tabular}

